\title{
ECUADOR \\ TRADE AND INVESTMENT COMPETITIVENESS \\ REPORT
}

Macroeconomics, Trade, and Investment Global Practice

The World Bank Group

June 2019 


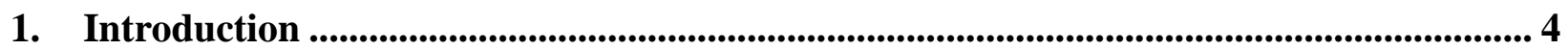

2. International Competitiveness Outcomes ..................................................................................... 12

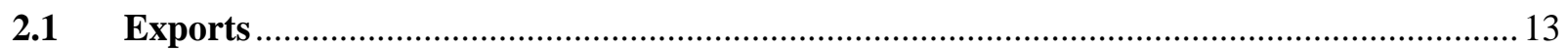

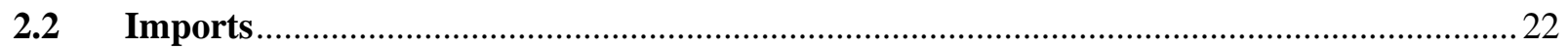

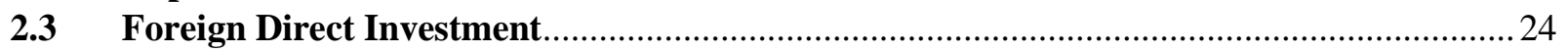

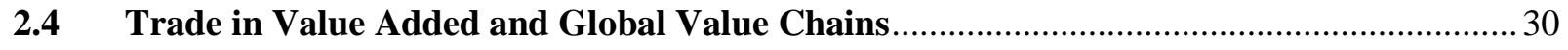

2.5 Key Challenges in Integrating with the Global Economy ............................................. 33

3. Competitiveness Diagnostic ................................................................................................. 35

3.1 Institutional Framework for Trade and Investment Policy and Promotion ......................35

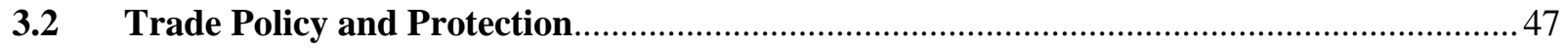

3.3 Labor Market Regulations and Labor Productivity: the Achilles heel of firm

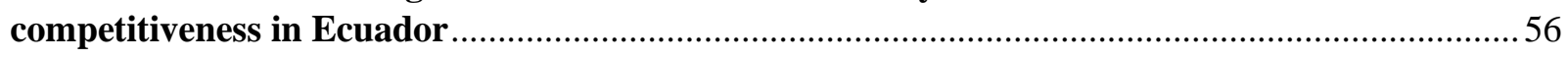

3.4 An Analysis of Minimum Price Supports in Ecuador .................................................. 75

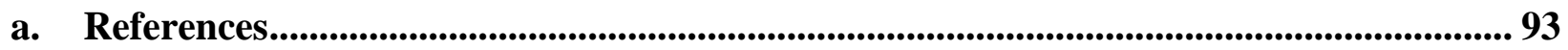

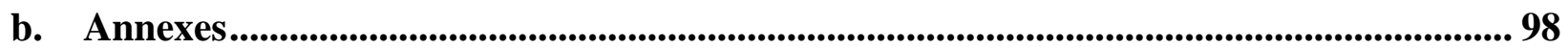

i. Empirical exercise to estimate foreign firms' markups. .................................................... 98

ii. Institutional frameworks for trade and investment: Chile, Costa Rica, and Ireland.........99

iii. Impact of the Pacific Alliance on the Competitiveness of Ecuadorian Exporters and

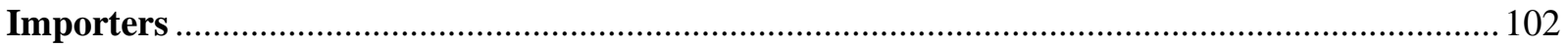

iv. Effects of Ecuador's Trade Protection on Productivity, Value Added, and Factor

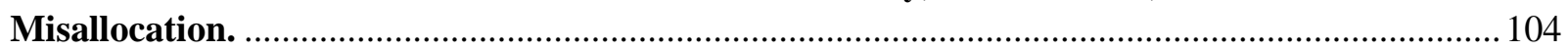

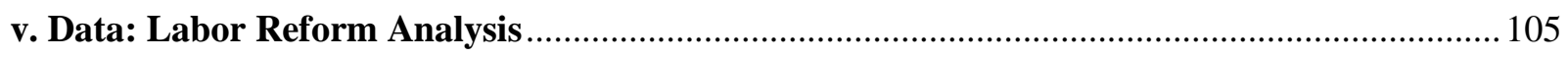

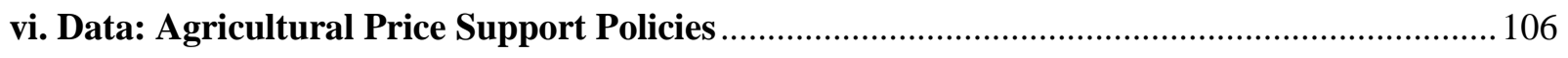




\section{Acknowledgements}

The preparation of the project was led by Barbara Cunha (Senior Economist, GMTLC), JoseDaniel Reyes (Senior Economist, GMTIC), and Samuel Pienknagura (former Senior Economist, GMTLC). The team gratefully acknowledges the guidance of Alberto Rodriguez (Country Director), Pedro Rodriguez (Program Leader, LCC6C), and Jorge Araujo (Practice Manager, GMTLC). The outcomes analysis section was conducted by Jose-Daniel Reyes, Esteban Ferro (Senior Consultant, GMTLC), and Guillermo Arenas (Economist, GMTRI). Gabriela Llobet (Senior Legal Consultant, GMTIC) and Philippe De Bonneval (Legal Consultant, GMTIC) produced a background note on the institutional assessment for trade and investment in Ecuador. The trade policy analysis was led by Jose-Daniel Reyes, Mariana Vijil (Economist, GFCLC), Esteban Ferro, and Lucas Zavala (consultant, GMTIC). Ivan Francisco Gachet (Consultant, GMTLC) provided a background note on the labor market. Anne Brockmeyer (Senior Economist, GMTLC), Jakob Brounstein, and Spencer Smith provided a background note on the impact of the tax on capital outflows. Ashwini Rekha (Agricultural Economist, GFAO4) provided a background note on the impact of agricultural support policies. Peer reviewers were Jakob Engel (Economist, GMTRI) and Ivan Nimac (Lead Private Sector Specialist, GMTCI).

We would also like to thank the Central Bank of Ecuador, the Super intendency of Societies, the Domestic Revenue Service, and the Ministry of Production, Foreign Trade, Investment, and Fisheries for support gathering information and the guidance on the most relevant topics to explore. 


\section{Introduction}

The internationalization of the Ecuadorian economy is necessary if the country is to successfully adopt a development model led by the private-sector. Connection to international markets through exports, imports, Foreign Direct Investment (FDI), and Global Value Chains (GVCs) is paramount. This will allow Ecuador to expand market opportunities for local enterprises as well as increase their scale and productivity. The country will also stand to benefit from the efficient reallocation of factors of production in the economy. Ultimately, all these elements together promise to foster future economic growth. By exposing companies to fierce competition in international market, exports push domestic firms to specialize and, in turn, to improve their operations and production processes. Imports, meanwhile, allow firms and consumers to access high-quality inputs and final products that may not be available locally or that may be overly expensive. FDI firms create jobs as well as bring frontier technology and know-how that could potentially be transmitted to the host economy, thereby increasing the productivity of local firms. GVCs, meanwhile, help domestic firms to increase their scale and productivity. This is in large part because of the access that GVCs give to global production networks. An important ancillary benefit is the knock-on effect of the expert, international standards to which exporting firms are consequently exposed.

The Ecuadorian government is seeking to accelerate growth and sustain social progress by giving greater prominence to the private sector; it does at a time when external conditions are less favorable than at any time in the last decade. Low and volatile oil prices are likely to be the 'new normal' for the years to come. In addition, the normalization of monetary policy in the United States and Europe could further tighten Ecuador's external financing conditions. Less favorable external conditions impact public coffers and push Ecuador to revisit its state-led growth process, which is no longer sustainable. Three key elements must be in place to enable Ecuador's transition to a more balanced, productivity-led growth model: (i) macroeconomic stability; (ii) efficient resource allocation in the public and the private sectors; and (iii) protection for the poor and the vulnerable. ${ }^{1}$ Bringing the fiscal accounts to a sustainable position is essential for reducing uncertainties, relieving external pressures, and safeguarding the country's dollarization regime. As the public sector downsizes, the private sector must take a leading role here. For this to happen, however, favorable conditions for private-sector development must be in place. This entails revamping policies to attract foreign investment and thereby integrate Ecuador's economy with the rest of the world. It is also necessary to reduce barriers to trade, better align labor costs and regulations with the needs of a productive and modern economy, modernize the national trade policy framework, and create a stronger role for the financial sector.

This Trade and Investment Competitiveness Report has three main objectives; to provide a systematic benchmark of Ecuador's connection to the global economy, to identify key

\footnotetext{
${ }^{1}$ Ecuador SCD 2018
} 
bottlenecks, and to make recommendations for enhancing the competitiveness of the private sector. The assessment is broken down into two sections. First, there is a section about international competitiveness outcomes, which assess Ecuador's performance and identifies the challenges associated with connecting to international markets. The analysis looks at outcomes throughout the four competitiveness channels; i.e. exports, imports, FDI, and GVCs. ${ }^{2}$ The report's second main section contains a competitiveness diagnostic about the key drivers behind the previously identified challenges and provides actionable policy recommendations to overcome them. The determinants are grouped in four mutually exclusive groups: (i) the macro/fiscal framework; (ii) the institutional and regulatory framework governing trade and investment; (iii) supply-side factors; and (iv) demand-side factors. The diagnostic framework is presented below in Figure 3.

Figure 1: Trade and Investment Competitiveness Diagnostic Framework

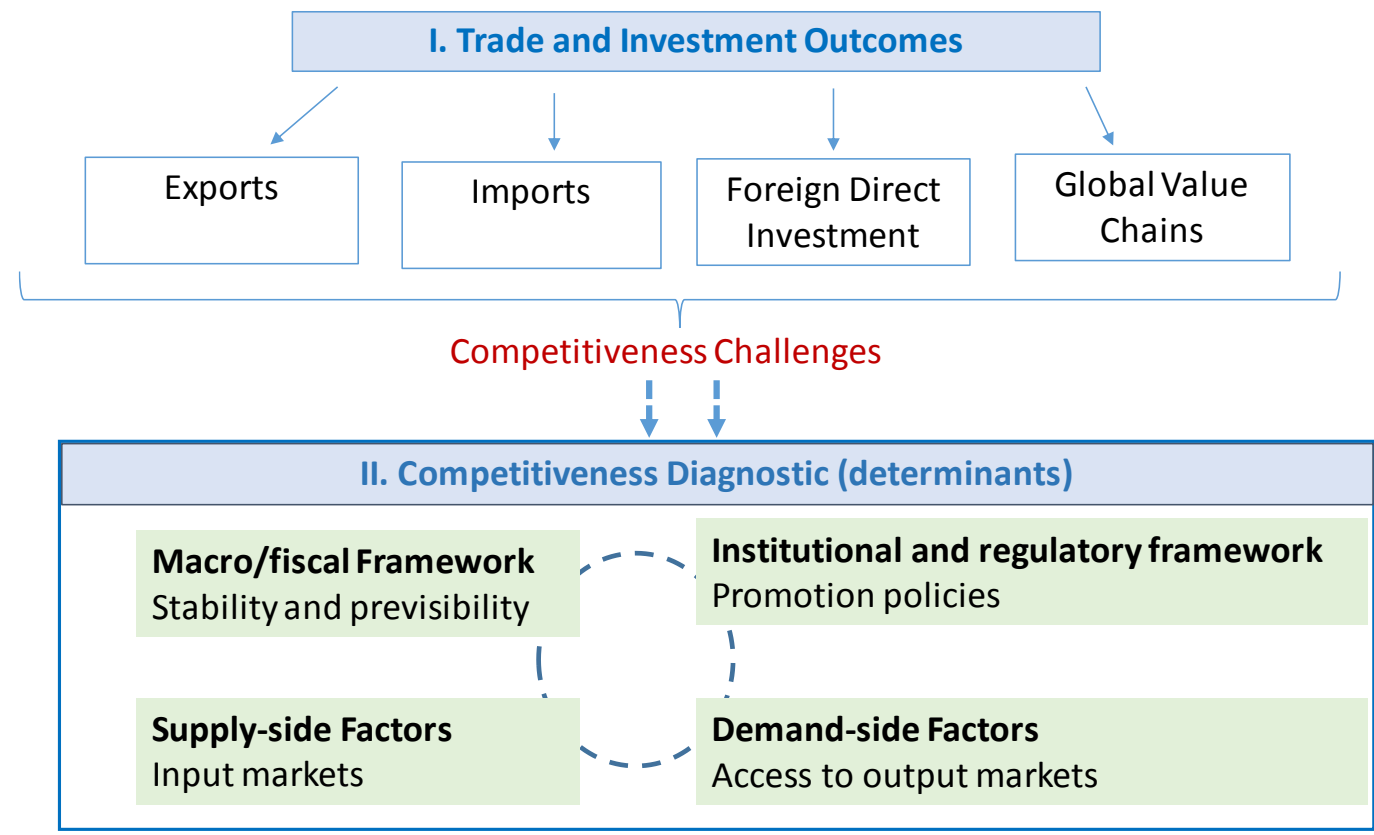

Given the protectionist policy stand prevalent during the last decade, Ecuador faces important hurdles when it comes to connecting with the global economy. The most important competitiveness challenges identified in this report relate to:

\footnotetext{
${ }^{2}$ The analysis evaluates Ecuador's trade dynamics overtime and benchmarks its situation with similar countries in the region. The analysis is concentrated on merchandise trade; services trade is purposely excluded from the analysis. Two types of information are employed. The first are publicly available trade data from the UN COMTRADE database available through the World Integrated Trade Solutions platform - the World Bank Group gateway for trade data and analysis. The second are confidential firm-level trade information and the financial statements of all formal companies shared by the government for this study. FDI information was obtained from UNCTAD and Ecuador's Central Bank.
} 
1. Exports: The high concentration of exports that Ecuador has around a few products with low value added or natural resources makes the country vulnerable to fluctuations in international prices. In comparison with relatively similar countries, Ecuador has fewer exporters, lower entry rate of firms into exporting, larger firms upon entry, and higher survival rates. These facts indicate disproportionally high fixed costs to export in Ecuador when compared with similar countries. A direct relationship exists between firm-level productivity and the fixed costs to export. In light of this, it is notable the relatively few firms in Ecuador that export tend to have better outcomes (size and survival) than firms in similar countries. This indicates that firms in Ecuador need to be relatively more productive in order to afford the relatively high export costs that they face. Some of the factors increasing the cost to export are discussed below.

2. Imports: During the last decade, import performance in Ecuador has broadly followed the international oil price cycle. To keep the trade deficit in check when oil prices dropped, the government implemented a range of interventions to curb imports. This reduced the ability of firms to access imported inputs in a stable and predictable manner, the impact of which was felt particularly by those either seeking to connect to regional value chains or those already connected. Ecuador's share of capital imports has been consistently reducing since 2012 as a result of the government's interventionist measures.

3. Foreign Direct Investment: The development model prevalent during the last decade has prioritized public investment over private investment. Between 2005-2015, flows of FDI accounted for less than 1 percent of GDP. This compares to an average rate of 3-7 percent for neighboring countries. Foreign investors in Ecuador are heavily concentrated in the extractive sector, which limits knowledge transfers from multinational corporations to the local economy. Recently, however, FDI flows have started expanding into other sectors, such as business services, retail and wholesale, and agriculture. Even so, the overall stock of FDI in the country remains low.

4. Global Value Chains: Ecuador's connection to regional or global value chains is limited. The degree of participation in GVCs is below that of Chile, Peru, and Mexico. Over the last decade, Ecuador's import substitution policy has increased the domestic value added embedded in the country's gross exports. This has occurred at the expense of using foreign inputs that could have allowed the country to connect with international production chains. As a result, Ecuador is now located upstream in the GVCs in which it participates, indicating its specialization in primary products with low value added.

While a wide range of factors have contributed to increasing the cost for Ecuadorian firms looking to connect to international markets, this report focuses on four priority areas for increasing the country's competitiveness in the short to medium run. It investigates how new or recently introduced policies are hampering the ability of firms to participate and benefit from 
international trade and FDI. In each of the four focus areas, the report offers policy recommendations to overcome present barriers (Table 1 present the list of recommendations). These areas and key policy recommendations are summarized as follows:

1. The institutional framework for trade and for investment policy and promotion: The creation in 2018 of the Ministry of Production, Foreign Trade, Investment, and Fisheries consolidated the functions and programs of four ministries under a single umbrella ministry. The goal of this reform, which was undertaken in the context of limited fiscal resources, was to increase the efficiency and coordination of the public sector's promotion of private-sector development and international trade. The organization of the new ministry broadly follows international best practices. However, there are three areas in which the new institutional model can be improved. First, responses to requests by exporters and investors could be made more swiftly. Slow responses times began occurring after the absorption of the trade and investment promotion agency into the new ministry. International practices indicate that promotion agencies are technical and specialized bodies that focus more on policy implementation than bureaucracy, which is more proper to a ministry. The absorption of the agency should therefore be reassessed. Secondly, investment promotion functions need to be revamped. Contrary to what its name suggests, the Sub-Secretariat for Investment Promotion currently focuses more on investment policy and regulation than on actual investment promotion. A clear, proactive strategy for promoting investment is required. If FDI into Ecuador is to become more diversified, then it is important that this strategy targets a variety of sectors (i.e. not just mining). Thirdly, the new ministry should be the lead technical entity responsible for defining Ecuador's international trade and investment policies, including bilateral agreements. At present, Decree No. 252 gives this responsibility to the Ministry of Foreign Affairs. To improve institutional coordination in international negotiations, it is important to clarify this apparent inconsistency.

2. A modern trade policy standpoint: Ecuador's trade policy during the last decade was characterized by a passive standpoint internationally and a protectionist stance locally. This hampered the international competitiveness of domestic enterprises. In particular, the decision to remain outside the Pacific Alliance Agreement decreased Ecuador's overall exports by an estimated 16 percent. This corresponds to a loss of $\$ 600$ million per year. Given that Colombia and Peru are natural trading partners for Ecuador, and that Chile and Mexico are substantial emerging economies, joining this regional agreement should be a priority for the government. Over the last decade, Ecuador has enacted import substitution policies aimed at incentivizing domestic value addition, protecting jobs, and developing the productive sector. These policies, which have mostly taken the form of protecting downstream sectors and liberalizing upstream sectors, have resulted in unintended consequences. Not only have they affected negatively Ecuador's value added, but they have also restrained total factor productivity growth. To counter these negative effects, it 
is necessary to rationalize the wide array of compound tariffs and other import duties applied in Ecuador. Such a move would have a positive impact on productivity growth because it would reallocate factors towards more productivity firms, especially if accompanied by reforms to reduce rigidities and price distortions for key inputs such as labor and agricultural products.

3. A flexible and efficient labor market: Labor market policy during the last decade have caused labor costs to grow above inflation and have reduced flexibility of employment arrangements, thus undermining firm competitiveness. In 2008, the Constitutional Assembly banned hourly contracts, as well as intermediation and outsourcing. Contracting workers through a third-party service provider (outsourcing) is now only allowed for a limited number of activities; namely, security, catering, delivery, and cleaning. In 2015, the Law for Labor Justice imposed additional constraints by prohibiting fixed-term employment contracts. In addition, complex and ad hoc mechanisms for setting the minimum wage have led to an 82-percent increase in real-term minimum wage payments over the last decade. This is well above the 25-percent increase in output per worker witnessed in Ecuador during this period. While the impacts of these policies on employment were moderate during the economic boom, they amplified significantly during the slowdown. Today, these effects are evident in the sharp increase in informality. Findings also suggest that many of the policy changes introduced over the last decade have been detrimental to firm productivity. Going forward, it is important to reform the minimum wage structure and to establish a mechanism that gradually aligns the minimum wage to productivity levels. It is also important to address the excessive rigidity that punishes firms and vulnerable groups, particularly young people and women. Two policy options here would be to reinstate hourly contracts (at least for young adult workers) and to reduce the country's high dismissal costs. In parallel with these measures, it is important to redesign the unemployment insurance system so that it provides an effective safety net for workers as they relocate to other jobs.

4. Agricultural support policies: In recent years, support towards farmers has grown significantly, reaching $\$ 1$ billion in 2016. Price support has increased considerably since 2014, especially for products such as rice, corn and milk, which benefit from both border protection measures and minimum price support (MPS) for producers. The MPS system guarantees above market prices, encouraging overproduction. Under the system, the government steps in to purchase any oversupply. In the case of rice, MPS has increased incrementally over recent years. In 2013, for example, producers received $\$ 33.9$ per ton. By 2016, this figure had more than quadrupled, reaching $\$ 153$ per ton. For corn, the price has stayed more stable, remaining at around $\$ 100$ per ton since 2014. As regards milk, MPS became significant in 2016, whereas for bananas it can be considered neutral since 2013. The benefit of increased price support for producers of rice, corn, and milk is that it 
has kept production relatively stable. Less positive, however, is its impact on producers' participation in external markets, which has reduced severely. The opposite tendency is observed in the case of banana production. Here, the price support from the government has been neutral and export values have increased and significantly over time. Moreover, for most of the products covered by the MPS system, overall production is concentrated among large-scale producers. As a consequence, these producers receive the largest share of the market price benefits. A clear knock-on effect of Ecuador's MPS policy is higher prices for consumers. Producers using the products targeted by the price policy as inputs also face higher costs, which harms their competitiveness and that of the wider production chain. Going forward, it is important to consider alternative programs that support the enhancement of agricultural productivity, rather than policies that distort prices and undermine competitiveness.

Table 1: Policy recommendations by strategic area

\begin{tabular}{|l|l|}
\hline \multicolumn{1}{|c|}{ Recommendation } & Timing \\
\hline Institutional framework for trade and for investment policy and promotion & ST \\
\hline $\begin{array}{l}\text { Promote collaboration and coordination between the vice-ministries of the } \\
\text { umbrella ministry }\end{array}$ & - \\
\hline $\begin{array}{l}\text { Transfer the responsibility of negotiating and subscribing international investment } \\
\text { agreements Ministry of Production, Foreign Trade, Investment and Fisheries } \\
\text { direction on investment matters }\end{array}$ & ST \\
\hline $\begin{array}{l}\text { Focus COMEX mandate on defining the overall direction of Ecuador's foreign } \\
\text { trade policies and coordination of actors }\end{array}$ & ST \\
\hline $\begin{array}{l}\text { Align export and investment promotion agencies with international best practices } \\
\text { by making then technical and specialized executing entities, with considerable } \\
\text { autonomy and budgetary independence from lead ministries. }\end{array}$ & ST to MT \\
\hline $\begin{array}{l}\text { Strengthen ProEcuador's investment promotion mandate to provide professional } \\
\text { support services to investors throughout the investment life cycle. }\end{array}$ & ST to MT \\
\hline Modern trade policy standpoint & ST \\
\hline Advance negotiations to join the Pacific Alliance & ST to MT \\
\hline Step-up the efforts to negotiate trade and investment agreements & \\
\hline
\end{tabular}

${ }^{3}$ ST- shot- term, MT medium-term 


\begin{tabular}{|c|c|}
\hline Gradually rationalized and phase out compound tariffs and other import duties & ST to $\mathrm{MT}^{4}$ \\
\hline \multicolumn{2}{|l|}{ Flexible and efficient labor markets } \\
\hline $\begin{array}{l}\text { Simplify minimum wage structure, eliminating sectorial minimum wage by } \\
\text { occupation and focusing on one universal minimum wage }\end{array}$ & ST \\
\hline $\begin{array}{l}\text { Create a metric (formula), link to inflation and productivity gains, to guide } \\
\text { minimum wage increases. }\end{array}$ & ST to MT \\
\hline Reinstate term and part time contracts & ST \\
\hline Reinstate hourly contracts & $\mathrm{MT}^{5}$ \\
\hline $\begin{array}{l}\text { Rationalize dismissal costs by imposing a cap on severance payments, and } \\
\text { reducing or eliminating payments for voluntary resignation }\end{array}$ & ST \\
\hline $\begin{array}{l}\text { Reduce the minimum mandatory profit-sharing rate (currently and } 15 \% \text { ) and } \\
\text { rationalize its application (e.g. exclude firms in the first years of operation) }\end{array}$ & ST to MT \\
\hline $\begin{array}{l}\text { Reform the unemployment ensures to ensure it is an effective safety-net under } \\
\text { more flexible labor regulations- speed up access, simplify processes, expand the } \\
\text { benefit to independent workers }\end{array}$ & ST to MT \\
\hline \multicolumn{2}{|l|}{ Agricultural support policies } \\
\hline Abolish MPS and substitute them to other support models & ST \\
\hline Gradually phase out import tariffs and quotas on agriculture products & ST to MT \\
\hline Provide targeted subsidies or guarantees to land development loans & ST \\
\hline Provide targeted subsidies or grants to irrigation investments & ST \\
\hline Facilitate access to fertilizers & ST \\
\hline $\begin{array}{l}\text { Develop disaster monitoring systems and forecast weather information } \\
\text { programs }\end{array}$ & St to MT \\
\hline Develop insurance mechanisms against weather shocks & MT \\
\hline Facilitate training and relocation of agriculture workforce & $\mathrm{ST}$ \\
\hline
\end{tabular}

\footnotetext{
${ }^{4}$ It is important to proceed with these reforms gradually and carefully coordinated them with other fiscal and structural reforms to increase competitiveness. An abrupt and premature broad-based tariff cut could amplify external imbalances in the short run.

${ }^{5}$ Require constitutional changes and intense consensus building among stakeholdes.
} 
The remainder of this report is structured as follows. The next section benchmarks Ecuador's performance along four dimensions of international competitiveness, while also identifying key constraints. Section 3 then discusses the five policy areas that are critical for increasing the ability of Ecuadorian firms to connect with the global economy. The section concludes by providing actionable policy recommendations. 


\section{International Competitiveness Outcomes}

Ecuador is relatively closed to foreign investment and international trade. The stock of FDIto-GDP and the trade-to-GDP ratios are two of the most basic indicators of integration to global markets. The former ratio evaluates the role of external capital in the economy. The latter ratio combines the importance of exports and imports in an economy. It also indicates the importance of foreign demand for domestic producers, on the one hand, and of foreign supply for domestic consumers and producers, on the other. When compared to countries with similar per capita income rates, Ecuador is well below its potential for both ratios. The stock of investment as a share of Ecuador's GDP, for example, is the lowest within its comparator nations and well below the potential curve. Its score for trade openness, meanwhile, is similar to that of Peru, but lower than that of Chile or Romania (Figure 2).

Figure 2: Benchmarking Ecuador's Integration into Global Markets (2014-2017)

Stock of FDI

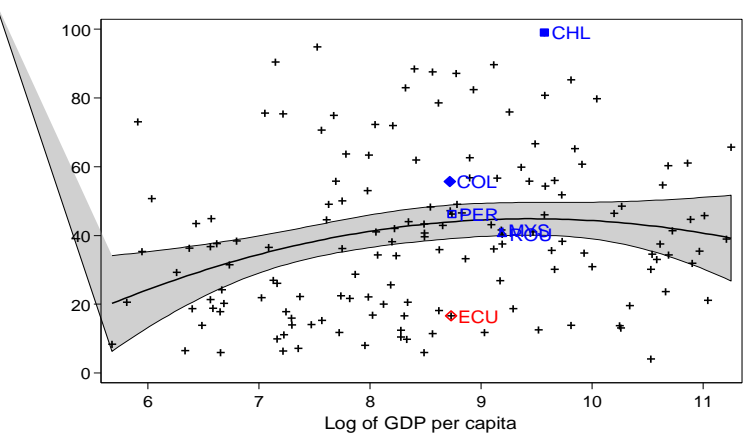

Trade Openness

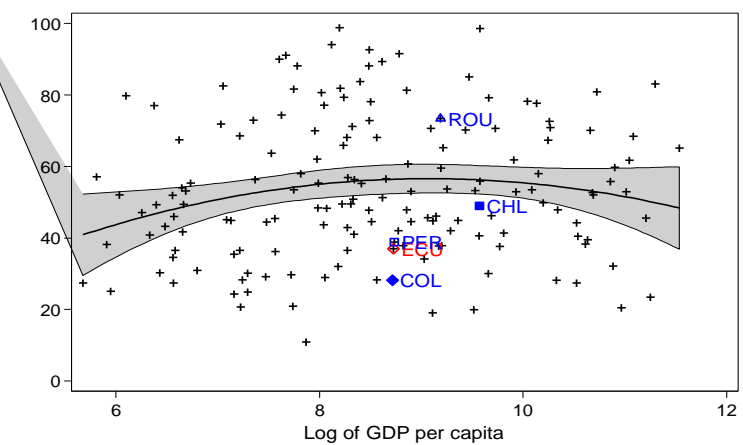

Note: These figures benchmark Ecuador trade openness and the stock of FDI with respect to all countries in the world. Each dot in the figure indicates a country. The dotted line represents the expected value of each indicator for a given per capita income, controlling for GDP per capita and GDP per capita squared. The gray area is the 95 percent confidence interval. Ecuador and some regional peers are identified by the ISO codes.

Source: Authors' computation using data from the World Development Indicators and UNCTAD.

Boosted by a booming oil sector, Ecuador's trade deficit fluctuated at around 0.5 percent of GDP during the last decade. The non-oil trade deficit accounted for around 7 percent of GDP during this period, indicating the importance of the oil sector's role as a generator of income and a stabilizer of the balance of payments. Between 2013-2016, the non-oil trade deficit was reduced from almost 10 percent of GDP to 1.7 percent. This reflects the government's policy of trying to contain imports and maintain the trade balance in check after international oil prices dropped sharply in 2014. Ecuador also put into effect a series of safeguards to ensure the stability of its balance of payments (Box 1) The deficit grew again after temporarily policies started to be phased out, reaching 6.1 percent of GDP in 2018. The country receives little FDI. Annual flows during the last decade accounted for less than 1 percent of GDP, barely covering the external deficit (Figure 3). 


\section{Box 1. Balance of Payments Safeguards in Ecuador}

In March 2015, the Ecuadorian government implemented safeguard tariffs on imports as a response to the deterioration of the balance of payments following the fall in oil prices. This measure drew on provisions in the General Agreement on Tariffs and Trade 1994 that allow countries facing balance-ofpayments problems to impose restrictions on imports (see Art. XII and XVIII section B). The tariff surcharge covered 2,955 ten-digit subheadings, representing 38 percent of the 7,581 subheadings and 31 percent of total import value in 2014. The safeguards were applied on the cost, insurance, and freight value of imports. They consisted of an ad valorem surcharge of 5, 15, 20, 25 and 45 percent, which mostly affected non-agricultural products (GATT 2019).

These safeguards were only supposed to remain in place for 15 months, with a progressive phase-out starting in January 2016. However, Ecuador experienced an earthquake in April 2016 that severely damaged its coastal regions. As a result, the safeguards were extended for another year. A partial phaseout then began in July 2016; the safeguards were then completely removed in June 2017.

Source: World Trade Organization. 2019. Trade Policy Review. WT/TPR/S/383.

Figure 3: Trade Balance and FDI Flows (\% of GDP)

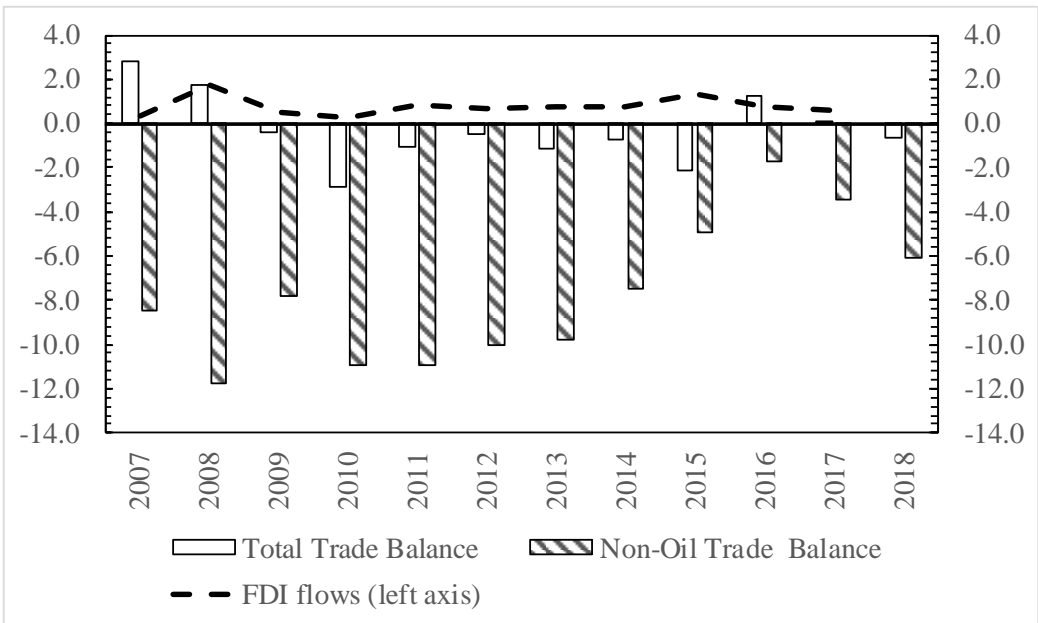

Note: This figure shows the evolution of trade balance and FDI flows in Ecuador during the last decade. It distinguishes between total trade balance and non-oil trade balance.

Source: Authors' computations using data from Ecuador's Central Bank.

\subsection{Exports}

Ecuador's export structure has traditionally been dominated by minerals and agricultural products, which jointly accounted for 90 percent of total export value in 2017. Mineral export - petroleum oils, primarily - made up about half of total exports in value ten years ago, reaching their highest participation (63 percent of total exports) when international oil prices peaked in 2008. By 2017, however, this figure had fallen back to 41 percent. Agricultural exports, on the 
other hand, accounted for 40 percent of total exports a decade ago. The dominant product categories here are fish and seafood, tropical fruits, and cut flowers. In recent years, exports of fish/seafood and fruits have increased. As a result, the agricultural sector has now become the most important generator of export revenues for Ecuador, accounting for over half (51.4 percent) of total export value today. The growing significance of agriculture is reflected in the fact that animal and food products represent two of Ecuador's fastest-growing export sectors, increasing by 6.8 percent and 6.3 percent over the last decade, respectively. Wood and stone/glass have also grown above average during this period, rising 5.1 percent and 7.1 percent, respectively. Together, the two sectors now make up just over 3 percent of exports. Ecuador has a comparative advantage in agriculture, minerals, and wood production (Table 2).

Table 2: Sectoral composition of the Export Bask (Value, exporters, and revealed comparative advantage)

\begin{tabular}{|c|c|c|c|c|c|c|c|c|}
\hline \multicolumn{2}{|r|}{ HS2 - Sector } & \multicolumn{3}{|c|}{2007} & \multicolumn{3}{|c|}{2017} & $\begin{array}{c}\text { Average Annual } \\
\text { Growth Rate } \\
\end{array}$ \\
\hline 01-05 & Animal & 226.0 & 984.6 & 6.3 & 267.0 & $1,901.0$ & 9.6 & 6.8 \\
\hline $06-15$ & Vegetable & $1,125.0$ & $3,854.2$ & 24.5 & $1,490.0$ & $5,431.8$ & 27.4 & 3.5 \\
\hline $16-24$ & Food products & 450.0 & $1,552.7$ & 9.9 & 613.0 & $2,863.2$ & 14.4 & 6.3 \\
\hline $25-27$ & Minerals & 83.0 & $7,795.0$ & 49.6 & 164.0 & $8,119.6$ & 40.9 & 0.4 \\
\hline $28-38$ & Chemicals & 400.0 & 113.3 & 0.7 & 542.0 & 111.4 & 0.6 & -0.2 \\
\hline $39-40$ & Plastic / Rubber & 310.0 & 114.2 & 0.7 & 442.0 & 161.0 & 0.8 & 3.5 \\
\hline $41-43$ & Hides, Skins & 319.0 & 12.0 & 0.1 & 181.0 & 12.7 & 0.1 & 0.5 \\
\hline $44-49$ & Wood & 713.0 & 256.1 & 1.6 & 595.0 & 421.5 & 2.1 & 5.1 \\
\hline $50-63$ & Textiles, Clothing & $1,245.0$ & 98.9 & 0.6 & 723.0 & 103.2 & 0.5 & 0.4 \\
\hline $64-67$ & Footwear & 398.0 & 39.1 & 0.2 & 268.0 & 35.0 & 0.2 & -1.1 \\
\hline $68-71$ & Stone / Glass & 503.0 & 98.6 & 0.6 & 366.0 & 206.0 & 1.0 & 7.6 \\
\hline $72-83$ & Metals & 438.0 & 256.2 & 1.6 & 512.0 & 298.4 & 1.5 & 1.5 \\
\hline $84-85$ & Mach/Elec & 617.0 & 200.9 & 1.3 & 710.0 & 137.5 & 0.7 & -3.7 \\
\hline $86-89$ & Transportation & 96.0 & 305.5 & 1.9 & 126.0 & 23.2 & 0.1 & -22.7 \\
\hline $90-97$ & Miscellaneous & 815.0 & 46.9 & 0.3 & 626.0 & 28.6 & 0.1 & -4.8 \\
\hline Total & & 3,263 & 15,728 & 100 & 3,623 & 19,854 & 100 & 2.4 \\
\hline
\end{tabular}

Note: This table shows Ecuador's exports across economic sectors in 2007 and 2017. For each year, it presents the number of exporters, the export value (in \$ millions), and the share of sectoral export value in total exports. The cells that are highlighted show the sectors in which the country displays a revealed comparative advantage as indicated by the Balassa (1965) index. The total of exporters for each year is not the sum of exporters in each sector because firms may export products across different sectors.

Source: Authors' computations using information from the Central Bank.

The number of exporters in Ecuador has grown little over the last decade and remains below other competitors in the region. The number of exporters went from 3,263 in 2007 to 3,623 in 2017. Currently, exporters represent 7 percent of all formal firms in the economy. They are mostly concentrated in the vegetable, textiles, and clothing sectors. In 2017, around 61 percent of exporters operated in these sectors, although they accounted for only 27.9 percent of the country's 
overall export value (Table 2). As a share of population, the relative number of exporters has decreased over the last decade and is currently below that of Uruguay, Mexico, Argentina, and Peru (

Figure 4).

Exporters represent a small fraction of firms in the economy, but they generate disproportionally more jobs than domestic enterprises. Across all sectors, exporters average 10 percent of local formal enterprises, yet they provide around 40 percent of sectoral employment. In sectors where Ecuador has a comparative advantage (see Table 2), the share of formal workers employed by exporters is close to 50 percent of all the workers in these sectors (

Figure 5).

Figure 4: Relative Number of Exporters

(2017)

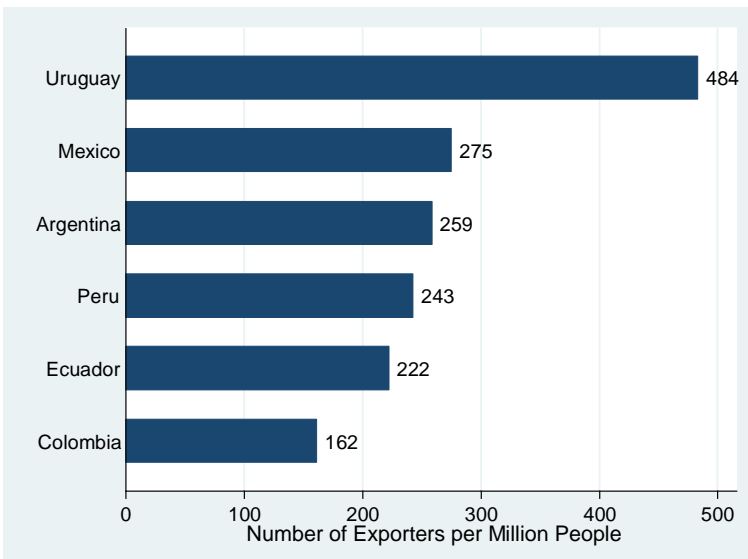

Note: This figure shows the number of exporters as a proportion of the population in a sample of six countries in the region.

Source: Authors' computation using information from the World Bank Exporters Dynamics Database.
Figure 5: Relative Importance of Exporters in Sectoral Employment (2017)

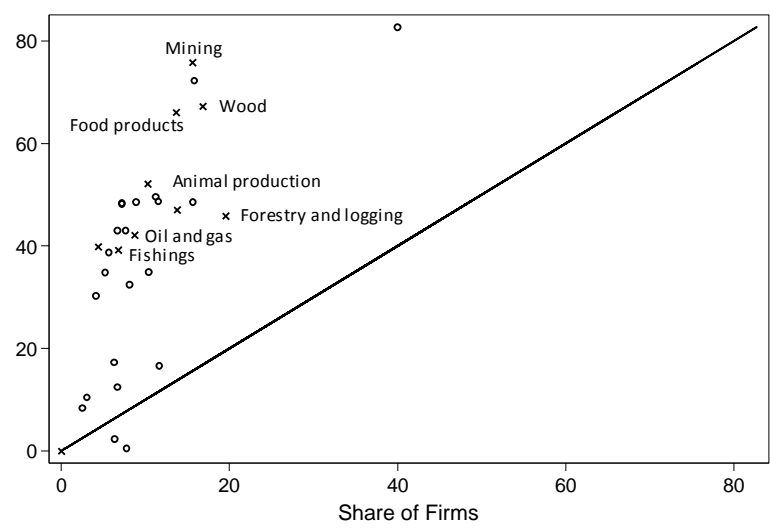

Note: This figure shows the relative importance of exporters in employment in Ecuador. Each point in the figure represents a three-digit CIIU code. An X represents a sector where Ecuador has a comparative advantage in exports according to the Balassa (1965) index. The vertical axis represents the exporters' share of formal employment in the given sector. The horizontal axis shows the number of exporters as a share of total firms in the sector.

Source: Authors' computation using information from the Superintendencia de Compañías.

On average, exporter firms in Ecuador are larger than non-exporters, they invest more, and they are more productive; yet, contrary to international evidence, they do not pay significantly higher wages, which points to important distortions in the labor market. 
Table 3 compares the different outcomes of exporter firms versus non-exporter firms. Wages are shown to be similar in both types of firms, particularly when the firms in question are large. The average wage per hour of large exporters is $\$ 0.90$; non-exporters pay $\$ 1$. The absence of any great difference in wage between more productive exporters and domestic oriented firms signals the many frictions present in the labor market. Overall, the findings indicate that exporters in Ecuador have the potential to contribute to aggregate productivity growth, job creation, and fiscal revenue.

Table 3: Firm-level Characteristics between Exporters and Non-Exporters (Medians)

\begin{tabular}{l|cr|cr|cr}
\hline & \multicolumn{2}{|c|}{ All firms } & \multicolumn{2}{c|}{ SMEs } & \multicolumn{2}{c}{ Large Firms } \\
& Exporters Non-Exporters & Exporters Non-Exporters & Exporters Non-Exporters \\
\hline \hline & & & & & \\
Gross Revenue & 334.0 & 16.2 & 18.9 & 8.8 & 530.0 & 113.0 \\
Employment (number) & 280 & 30 & 53 & 22 & 420 & 127 \\
Capital stock & 141.0 & 6.5 & 11.1 & 3.6 & 222.0 & 44.0 \\
Total Factor Productivity & 8.9 & 7.9 & 8.1 & 7.8 & 9.5 & 9.3 \\
Wage per hour (\$) & 0.8 & 0.6 & 0.6 & 0.6 & 0.9 & 1.0 \\
Profits & 25.8 & 0.9 & 1.1 & 0.5 & 41.2 & 6.7 \\
Taxes & 1.9 & 0.1 & 0.2 & 0.1 & 3.0 & 0.7 \\
FDI inflows & 2.4 & 0.1 & 0.2 & 0.0 & 3.8 & 0.5 \\
& & & & & & \\
\hline
\end{tabular}

Note: This table compares exporters versus non-exporters along different characteristics of firm performance. The median of the variable is reported.

Source: Mogro et al. 2019.

Ecuador's export basket concentrates on a small number of products exported by a small number of firms. The country's top ten export products by value in 2017 jointly accounted for 83 percent of total exports, for example (Table 4). Petroleum oil is the most important export product, making up 39 percent of total exports. Top agricultural exports, meanwhile, include bananas, frozen shrimps, preserved tuna, cut flowers, cocoa beans, and palm oil. Overall, these products represented around 25 percent of Ecuadorian exports in 2017. Mineral products (gold and precious metal ores) occupy third place, at 2.5 percent of total exports. Manufactured products are not found in the top ten (or top 20) export products. Exports are not only concentrated across products, but also across exporters. Nearly one third (30 percent) of exporters $(1,081)$, for example, are responsible for the exportation of Ecuador's top ten products.

Table 4: Top Export Products (2017) 


\begin{tabular}{ccl|rr|rr}
\hline \multirow{2}{*}{ Rank } & \multirow{2}{*}{ HS6 } & \multicolumn{1}{|c|}{ Product } & \multicolumn{2}{|c|}{ Exporters } & \multicolumn{2}{c}{ Exports } \\
& & & 7 & 0.2 & $7,745.6$ & 39.0 \\
& & & 226 & 6.2 & $3,925.2$ & 19.8 \\
1 & 270900 & Pumber & Share & Value & Share \\
\hline & 080300 & Bananas, fresh & 68 & 1.9 & $1,655.7$ & 8.3 \\
3 & 030613 & Frozen Shrimps and prawns & 30 & 0.8 & $1,066.2$ & 5.4 \\
4 & 160414 & Prepared or preserved tuna & 517 & 14.3 & 790.9 & 4.0 \\
5 & 060310 & Fresh cut flowers & 114 & 3.1 & 672.1 & 3.4 \\
6 & 180100 & Cocoa beans & 46 & 1.3 & 176.5 & 0.9 \\
7 & 261690 & Precious Metal ores & 45 & 1.2 & 160.2 & 0.8 \\
8 & 710812 & Gold & 22 & 0.6 & 160.2 & 0.8 \\
9 & 151110 & Crude Palm oil & 6 & 0.2 & 158.3 & 0.8 \\
10 & 210111 & Extract, essense, concentrates & & & & \\
\hline \hline
\end{tabular}

Note: This table shows the ten most important products in terms of export value in 2017. It presents the number of exporters, the export value (in \$ millions), and the product's share in the overall export basket. Source: Authors' computations using information from the Central Bank.

Ecuador shows a higher concentration of export bundle than its regional peers, although some progress has been made at increasing diversification over the last decade. Diversifying exports across products reduces the risk of extreme volatility in oil prices - something to which Ecuador's macroeconomic stability is perennially vulnerable. Research shows that the effect of trade openness on output volatility depends to some extent on the degree to which a country's export basket is diversified (Haddad et al. 2011). Ecuador performs poorly in this regard. Its export basket is the most concentrated among comparators. That said, it is the only country where the degree of concentration actually decreased between 2002 and 2017 (Figure 6).

While it is true that a few firms are responsible for the lion's share of Ecuador's export value, the level of concentration of exports across firms is low compared to similar countries in the region. In 2017, the top 5 percent of Ecuador's exporters accounted for 73 percent of total exports (Figure 7). This is consistent with the picture across Latin America, where a small number of large exporters typically make up the bulk of exports (Bernard and Jensen 1999; Bernard et at. 2007). Indeed, Ecuador's export market is more diversified than many of its regional peers, indicating the existence of many small and medium-sized exporters. Such diversification could also imply that these smaller-scale exporters face struggles in their attempts to grow.

Figure 6: Export Concentration on products (2017)
Figure 7: Export Concentration on Firms (2017) 


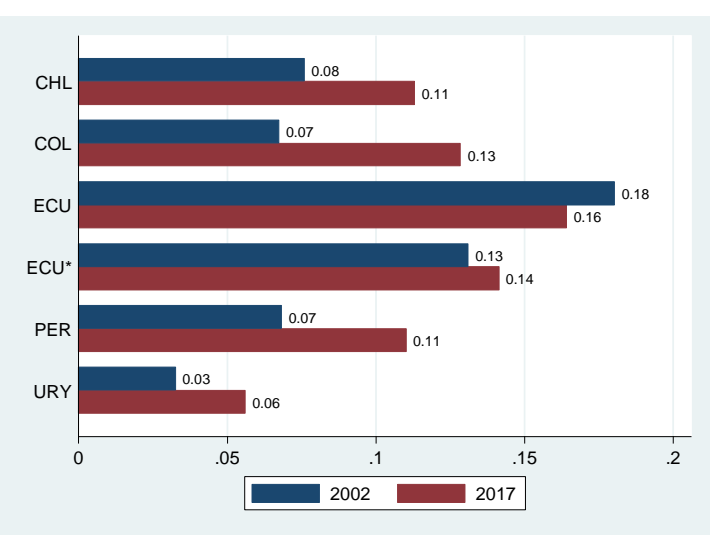

Note: This figure shows the concentration of export value across products. The indicator of export concentration is the Herfindahl-Hirschman Index (See Rhoades 1993).

Source: Authors' computation using information from the COMTRADE database

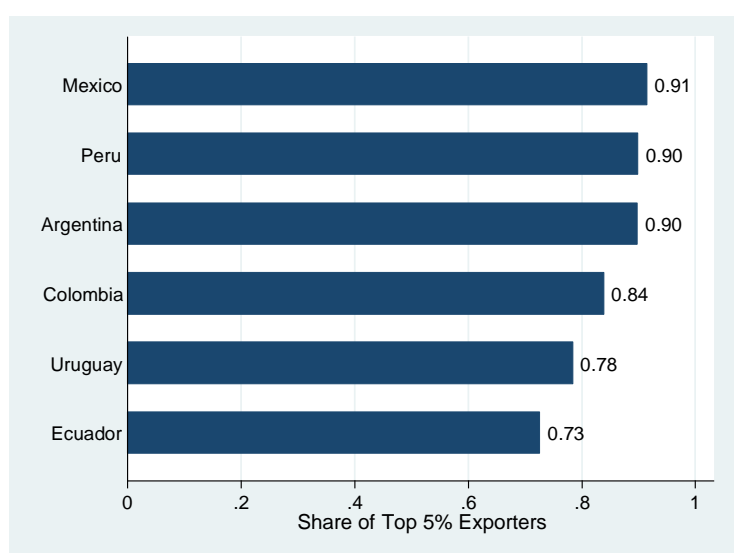

Note: This figure shows the share of export value of the top 5 percent of the largest exporters in six countries in South America.

Source: Authors' computation using information from the Exporter Dynamics Database.

The destination of the Ecuadorian export bundle is relatively diversified, with the United States and the European union as key trading partners. The United States is the main exporting partner of Ecuador (Table 5). However, its importance has declined over the last decade, from 40 percent in 2007 to 32 percent in 2017. Oil exports explain the large reliance of Ecuador in the U.S. market. For non-oil exports, the United States is the second biggest destination, representing around 15 percent of Ecuador's export basket.

The EU and Vietnam are important export markets for non-oil exports. On average, 15 percent of the total exports are destined for Europe, which represents the main market for non-oil products. Vietnam recently became the third most important destination for Ecuadorian exports. Since 2014, the growth of exports to Vietnam has been almost four times higher than that for the EU. This has almost compensated for the decline in exports to the United States. Other nontraditional destinations, such as Korea, Saudi Arabia, Indonesia, and Malaysia, have gained in importance over recent years. Collectively, these markets have generated an additional \$251 million in export revenues since 2014.

Table 5: Top Export Destination Markets (2007-2017) 


\begin{tabular}{|c|c|c|c|c|c|c|c|}
\hline \multicolumn{4}{|c|}{2007} & \multicolumn{4}{|c|}{2017} \\
\hline Country & Nbr firms & Value & $\%$ of total & Country & Nbr firms & Value & $\%$ of total \\
\hline United States & 1,448 & 6,397 & 40.7 & United States & 1,631 & 6,014 & 31.6 \\
\hline EU & 2,713 & 2,765 & 17.6 & EU & 4,844 & 3,166 & 16.6 \\
\hline Peru & 497 & 1,502 & 9.6 & Vietnam & 172 & 1,458 & 7.7 \\
\hline Chile & 440 & 759 & 4.8 & Peru & 567 & 1,276 & 6.7 \\
\hline Russia & 301 & 754 & 4.8 & Chile & 664 & 1,235 & 6.5 \\
\hline Colombia & 626 & 733 & 4.7 & Panama & 287 & 935 & 4.9 \\
\hline Venezuela & 192 & 280 & 1.8 & Russia & 639 & 845 & 4.4 \\
\hline El Salvador & 40 & 276 & 1.8 & China & 447 & 768 & 4.0 \\
\hline Japan & 150 & 205 & 1.3 & Colombia & 619 & 760 & 4.0 \\
\hline Canada & 341 & 204 & 1.3 & Japan & 198 & 389 & 2.0 \\
\hline & 6,748 & 13,874 & 88.2 & & 10,068 & 16,846 & 88.4 \\
\hline
\end{tabular}

Note: This table shows the ten most important markets in terms of export value in 2017. It presents the number of exporters, the export value (in \$ millions), and the destination country's share in the overall export basket.

Source: Authors' computations using information from the Central Bank.

In line with the pattern of the last two decades, the sophistication and technological composition of Ecuador's exports basket is dominated by primary and resource-based products. The goods that countries produce and how they produce them matter for export-led development. With everything else being equal, goods that embody greater value added in terms of ingenuity, skills, and technology tend to fetch higher prices in world markets. When countries produce goods that are more sophisticated than their income levels would suggest, they tend to see higher rates of future economic growth (Lall 2000; Hausmann et al. 2012). Figure 8 shows the evolution of exports according to technological classification, revealing that Ecuador's exports are unsophisticated even compared to its neighbor countries. Less than 10 percent of Ecuador's overall exports in 2017 consisted of technological products, for example, with most being of medium or low technological content. Between 2007 and 2017, the share of mid-tech and low-tech goods declined from 6.5 percent to 5.7 percent and from 3.5 percent to 2.1 percent, respectively. In contrast, primary products increased their share of national exports from 71.9 percent to 74.6 percent during the same period. The share of high-tech products in the country's external sales has experienced almost no change over the last 15 years.

\section{Figure 8: Technological Classification of Exports (2017)}

Figure 9: No Oil-export Sophistications (EXPY-2017) 


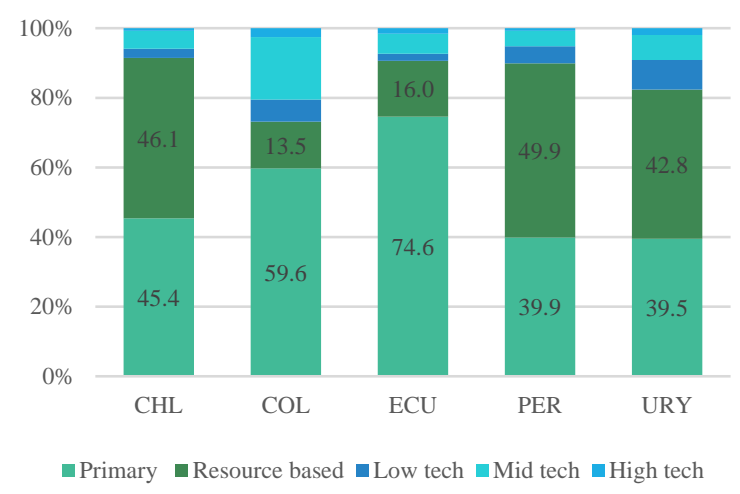

Note: This figure shows the concentration of export value across products. The indicator of export concentration is the Herfindahl-Hirschman Index (See Rhoades 1993).

Source: Authors' computation using information from the COMTRADE database

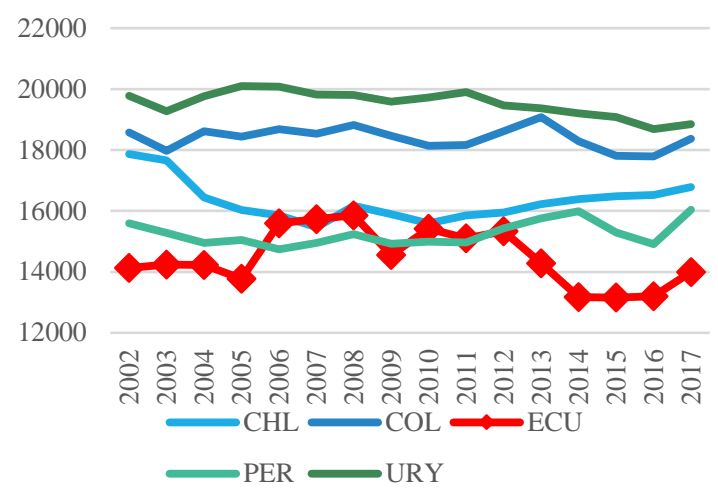

Note: This figure shows the share of export value of the top 5 percent of the largest exporters in six countries in South America.

Source: Authors' computation using information from the Exporter Dynamics Database.

Ecuador also shows the lowest level of product sophistication of non-oil products among comparators. The sophistication of Ecuador's export bundle has remained stable during the last 15 years. This is true of the country's regional comparators as well, all of which show a stagnation in the level of sophistication of their exports between 2002 and 2017. Figure 9 reveals that Ecuadorian non-oil exports are the least sophisticated among its comparators. The last couple of years have witnessed moderate improvement here, although levels of sophistication still remain broadly similar to what they were in 2002.

Firm-level export dynamism in Ecuador shows relatively low rates of entry and exit into international markets; when coupled with the fact that firms are relatively larger upon entry, this suggests that Ecuador either has disproportionate high fixed costs to export or minimum productivity scale. Countries that achieve fast export growth and diversification display the constant entry and exit of firms into international markets as well as high levels of firm survival. Since 2010, the rate in which Ecuadorian firms start and cease exporting has decreased (Figure 10). More worryingly is data from 2013-2016 that show a higher exit than entry rate, indicating a net reduction of exporters during this period. ${ }^{6}$ The Ecuadorian firms that can export are, on average, larger than in other countries in the region. In fact, the share of total export of entrants is 6 percent, two percentage points higher than the regional average (Figure 11). These firms also tend to survive relatively longer periods in international markets than their regional counterparts.

\footnotetext{
6 This confirms the fact that the number of firms exporting in Ecuador is low in relation to the country's level of development (
}

Figure 4) 
Box 2 presents the results of an econometric analysis that benchmarks firm-level dynamics in Ecuador.

\section{Figure 10: Firm-level Export and Entry} Rates in Ecuador

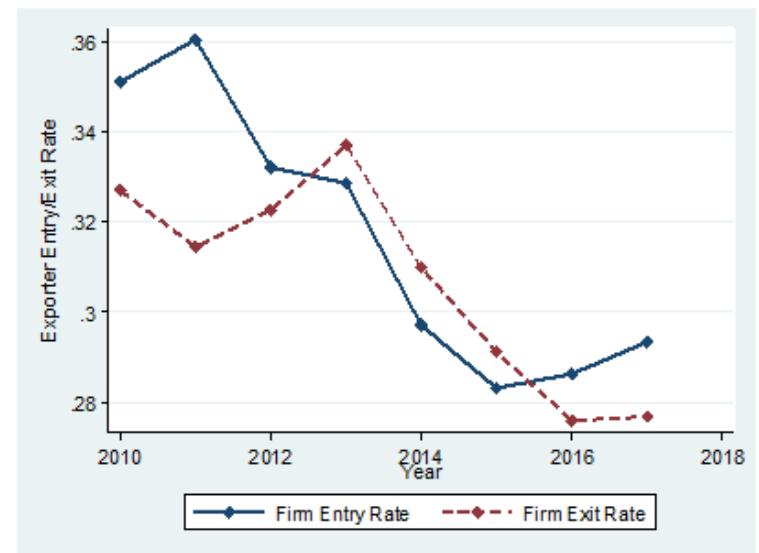

Note: This figure shows the evolution of entry and exit rates in Ecuador. Entrants (exiters) are identified as firms that export in year $t$ but not in year $t-1(t+1)$. The entry (exit) rate is computed as the share of entrants (exiters) in total exporters.

Source: Authors' computation using information from the World Bank Exporter Dynamics Database.
Figure 11: Share of Entrants in Total Export Value

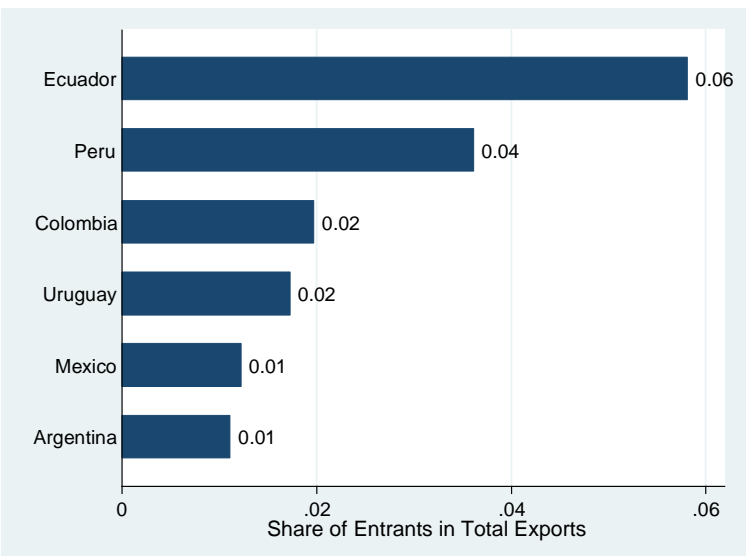

Note: This figure shows the share of entrants in total exports for a set of countries in the region for which firm level data is available.

Source: Authors' computation using information from the World Bank Exporter Dynamics Database.

\section{Box 2. Benchmarking firm-level export dynamics in Ecuador}

To benchmark the exporters in Ecuador against those in comparator countries, we rely on estimates from cross-country regressions whose dependent variables will be different indicators of export performance. The regression controls for the size (GDP) and the level of development (GDP per capita) of each country. It also controls for time trends, which is critical as the sample period encompasses recent commodity price shocks that have affected many of the countries in the sample. The cross-country regressions are estimated on a panel of country-year exporter competitiveness indicators covering the 2000-2017 period. The analysis encompasses all developing and developed countries included in the Exporter Dynamics Database (Annex 6.1 lists the countries included in the regression). Each regression includes a dummy variable identifying the observations for Ecuador. This estimate determines how Ecuadorian exporters perform relative to the benchmark countries. Table B.1 displays the results from the cross-country regressions, which provide the backbone for the analysis described in this section.

The benchmarking exercise provides the following results about the performance of Ecuadorian exporters, relative to countries at the same stage of development:

1. There are few exporters in Ecuador.

2. Existing exporters tend to be very large.

3. Exports are not very concentrated across firms.

4. Ecuadorian firms export, on average, fewer products but reach more destinations.

5. Both entry and exit rates of firms in international markets are very low. 
6. The few firms that enter tend to be large and have high survival rates.

These findings suggest that Ecuador has relatively large fixed export costs. It is possible to infer this because a direct relationship exists between the size of these costs and the firm-level productivity required to export (Melitz 2003). Hence, the relatively low level of Ecuadorian dynamism in international markets indicates that there are internal and external barriers that increase the costs of participating in international markets.

Table B.1: Benchmarking Ecuadorian Exporters Competitiveness

\begin{tabular}{|c|c|c|c|c|c|c|c|c|}
\hline VARIABLES & $\begin{array}{l}\text { Log Number } \\
\text { of Exporters } \\
\text { (1) }\end{array}$ & $\begin{array}{c}\text { Log Average } \\
\text { Exporter Size } \\
\text { (2) }\end{array}$ & $\begin{array}{l}\text { Log Median } \\
\text { Exporter Size } \\
\text { (3) }\end{array}$ & $\begin{array}{l}\text { Herfindahl } \\
\text { Index } \\
(4)\end{array}$ & $\begin{array}{l}\text { Share of Top } \\
1 \% \text { Exporters } \\
\text { (5) }\end{array}$ & $\begin{array}{c}\text { Share of Top 5\% } \\
\text { Exporters } \\
(6) \\
\end{array}$ & $\begin{array}{l}\text { Log Number of } \\
\text { Products per Exporter } \\
\text { (7) }\end{array}$ & $\begin{array}{c}\text { Log Number of } \\
\text { Destinations per Exporte } \\
(8) \\
\end{array}$ \\
\hline \multirow[t]{2}{*}{ Ecuador } & -0.357 & 0.074 & 0.404 & 0.002 & -0.080 & -0.055 & -0.367 & 0.275 \\
\hline & {$[0.043]^{* * *}$} & [0.048] & {$[0.122]^{* * *}$} & [0.008] & {$[0.024]^{* * *}$} & {$[0.014]^{* * *}$} & {$[0.029]^{* * *}$} & {$[0.054]^{* * *}$} \\
\hline \multirow[t]{2}{*}{ Log (GDP Percapita) } & 0.124 & 0.057 & -0.218 & 0.005 & 0.036 & 0.025 & 0.079 & 0.029 \\
\hline & {$[0.024]^{* * *}$} & {$[0.022]^{* * *}$} & {$[0.035]^{* * *}$} & {$[0.003]^{*}$} & {$[0.005]^{* * *}$} & {$[0.004]^{* * *}$} & {$[0.014]^{* * *}$} & {$[0.011]^{* * *}$} \\
\hline \multirow[t]{2}{*}{$\log (G D P)$} & 0.739 & 0.270 & 0.346 & -0.024 & 0.009 & -0.001 & 0.080 & 0.116 \\
\hline & {$[0.025]^{* * *}$} & {$[0.021]^{* * *}$} & {$[0.030]^{* * *}$} & {$[0.003]^{* * *}$} & {$[0.004]^{* *}$} & {$[0.003]$} & {$[0.014]^{* * *}$} & {$[0.011]^{* * *}$} \\
\hline Observations & 749 & 749 & 747 & 749 & 741 & 741 & 749 & 749 \\
\hline R-squared & 0.785 & 0.283 & 0.192 & 0.202 & 0.157 & 0.115 & 0.246 & 0.372 \\
\hline
\end{tabular}

\begin{tabular}{|c|c|c|c|c|c|c|}
\hline VARIABLES & $\begin{array}{l}\text { Exporter Entry } \\
\text { Rate } \\
\text { (1) }\end{array}$ & $\begin{array}{l}\text { Exporter Exit } \\
\text { Rate } \\
\text { (2) }\end{array}$ & $\begin{array}{l}\text { Share of Entrants } \\
\text { in Total Exports } \\
\text { (3) }\end{array}$ & $\begin{array}{c}\text { One-Year } \\
\text { Survival Rate } \\
\text { (4) }\end{array}$ & $\begin{array}{c}\text { Two-Year } \\
\text { Survival Rate } \\
\text { (5) }\end{array}$ & $\begin{array}{c}\text { Three-Year } \\
\text { Survival Rate } \\
\text { (6) }\end{array}$ \\
\hline \multirow[t]{2}{*}{ Ecuador } & -0.024 & -0.027 & 0.005 & 0.031 & 0.020 & 0.025 \\
\hline & {$[0.007]^{* * *}$} & {$[0.007]^{* * *}$} & {$[0.008]$} & {$[0.010]^{* * *}$} & {$[0.010]^{*}$} & {$[0.012]^{* *}$} \\
\hline \multirow{2}{*}{ Log (GDP Percapita) } & -0.017 & -0.009 & -0.007 & -0.022 & -0.018 & -0.015 \\
\hline & {$[0.003]^{* * *}$} & {$[0.003]^{* *}$} & {$[0.002]^{* * *}$} & {$[0.005]^{* * *}$} & {$[0.005]^{* * *}$} & {$[0.005]^{* * *}$} \\
\hline $\log (G D P)$ & $\begin{array}{c}-0.020 \\
{[0.002]^{* * *}}\end{array}$ & $\begin{array}{c}-0.021 \\
{[0.003]^{* * *}}\end{array}$ & $\begin{array}{c}-0.005 \\
{[0.002]^{* * *}}\end{array}$ & $\begin{array}{c}0.026 \\
{[0.004]^{* * *}}\end{array}$ & $\begin{array}{c}0.024 \\
{[0.005]^{* * *}}\end{array}$ & $\begin{array}{c}0.021 \\
{[0.005]^{* * *}}\end{array}$ \\
\hline Observations & 682 & 681 & 682 & 601 & 519 & 484 \\
\hline R-squared & 0.252 & 0.208 & 0.093 & 0.136 & 0.152 & 0.267 \\
\hline
\end{tabular}

Source: World Bank staff calculations

\subsection{Imports}

During the last decade, imports in Ecuador grew at a fast pace, driven by consumer and intermediate products; yet capital goods, which help increase the productivity of local enterprises, accounted for only 20 percent of import value in 2017. Following the same pattern as exports, imports doubled between 2007 and 2014. Afterwards they dropped back to around 40 percent of the import value in 2007 (Figure 12). The share of imports of capital goods has historically fluctuated between 20-30 percent of total import value. However, since 2015, it has consistently declined. Imports of consumer goods have increased in importance, on the other hand. This is despite government efforts to curb consumption imports. Imports of raw material account for 5 percent of total imports (Figure 13).

There are many more importers than exporters in Ecuador; although only a few firms both export and import, it is these firms that drive the country's overall trade pattern. Around 24,000 firms in Ecuador were connected to international trade in 2017 (Figure 14). These were 
mostly importers-only (81.6 percent), with exporters-only (11.6 percent) and firms that both export and import (6.8 percent) representing a minority. However, in 2017, exporter-importers accounted for 60 percent of the country's total import value and 75 percent of its export value. The importersonly group have expanded over the last decade, while exporters-only and exporter-importers have remained largely unchanged. ${ }^{7}$

Exporter-importers have grown increasingly over the last decade. In 2007, the median size of an exporter-importer was 13 times the median size of a pure importer. This rate reached 14 times in 2017, after peaking at 21 times in 2014 (Figure 15). A similar pattern is observed for exports, albeit slightly more nuanced. In 2017, the median exporter-importer was 2.1 times larger than the median pure exporter.

Figure 12: Import Value.

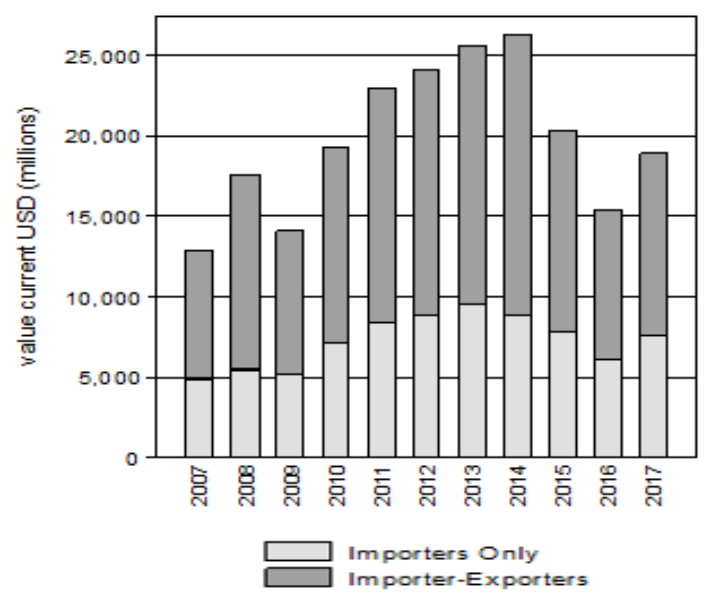

Note: This figure shows the evolution of import value in Ecuador during the last decade, by type of importer. Source: Authors' calculation using information from the Central Bank

\section{Figure 13: Imports by Stage of Production}

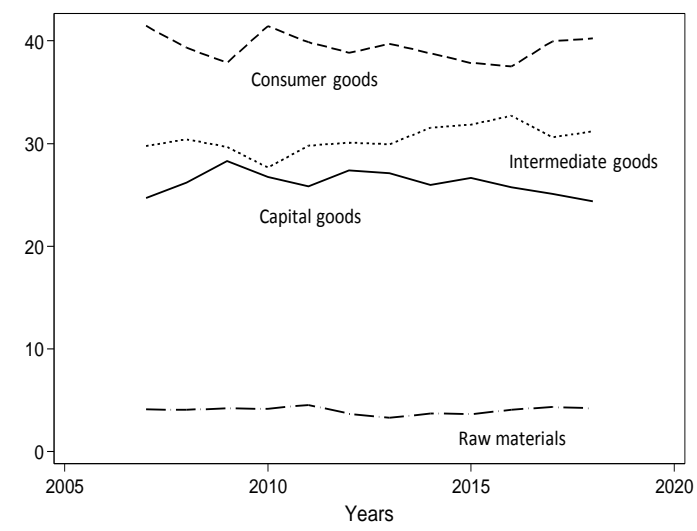

Note: This figure disaggregates import value by the stages in which products are processed.

Source: Authors' calculation using information from the Central Bank

\footnotetext{
${ }^{7}$ The data shows some churning of exporter-importers over time. However, entry and exit rates almost balanced each other out, thereby rendering the number of firms unchanged.
} 
Figure 14: Number of Traders.

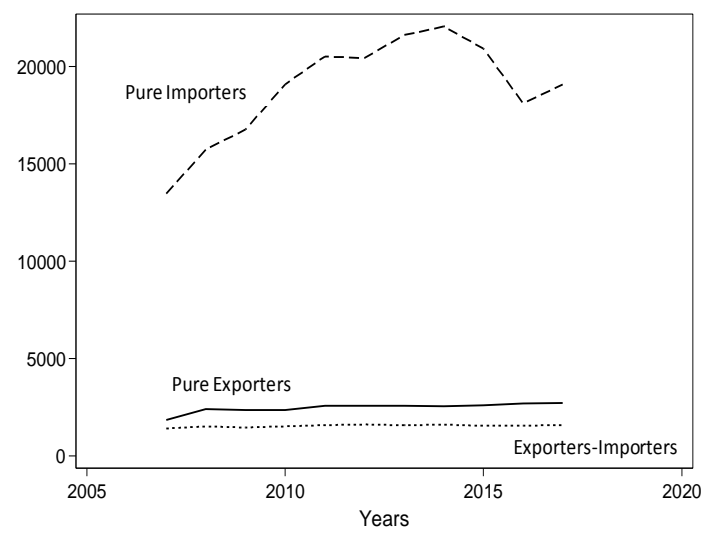

Note: This figure shows the evolution of the number of firms connected to international trade in Ecuador, by type.

Source: Authors' calculation using information from the Central Bank

\section{Figure 15: Median size of Importers}

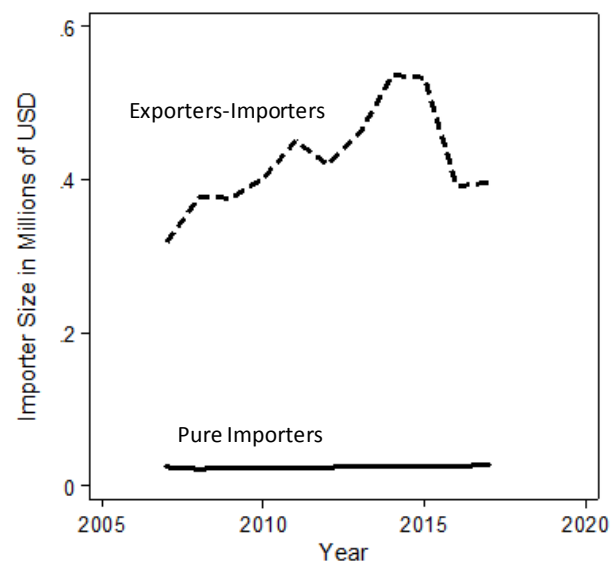

Note: This figure presents the median size of importers, by type.

Source: Authors' calculation using information from the Central Bank

Survival rates in international markets have decreased continuously since 2007; importerexporters have higher rates of survival upon entry than importers-only, but this difference tends to disappear over time. Around 45 percent of exporter-imports that started importing in 2007 survived for one year. The respective proportion for importers-only is 35 percent. However, by 2010,16 percent of these firms remained active in international markets.

\subsection{Foreign Direct Investment}

During the last decade, annual flows of FDI averaged less that 1 percent of Ecuador's GDP. Between 1998-2004, inflows of FDI fluctuated between 2-4 percent of GDP, which broadly aligns with Colombia and Peru (Figure 16). From 2005 onwards, annual FDI flows to Ecuador declined to less than 1 percent of GDP (except for 2008 and 2015). This marks a major divergence with Peru and Colombia, which both received flows of between 3 percent and 7 percent. The weak flow of FDI in Ecuador during this period translated into a very low level of foreign capital stock when compared to its regional competitors. Indeed, Ecuador went from having 20 percent of the stock of foreign investment held by Colombia, Peru, and Ecuador in 2000, to having a mere 6 percent by 2017 (Figure 17). ${ }^{8}$

\footnotetext{
${ }^{8}$ Comparing Ecuador to Panama and El Salvador (two other dollarized economies in the region), the same pattern of lost FDI competitiveness is observed. In 2002, Ecuador and Panama had the same stock of FDI as Ecuador. In 2017, however, the stock of FDI in Panama was three times that of the Ecuador, whereas the stock of FDI in El Salvador was almost double.
} 
Figure 16: FDI Inflows (\% GDP)

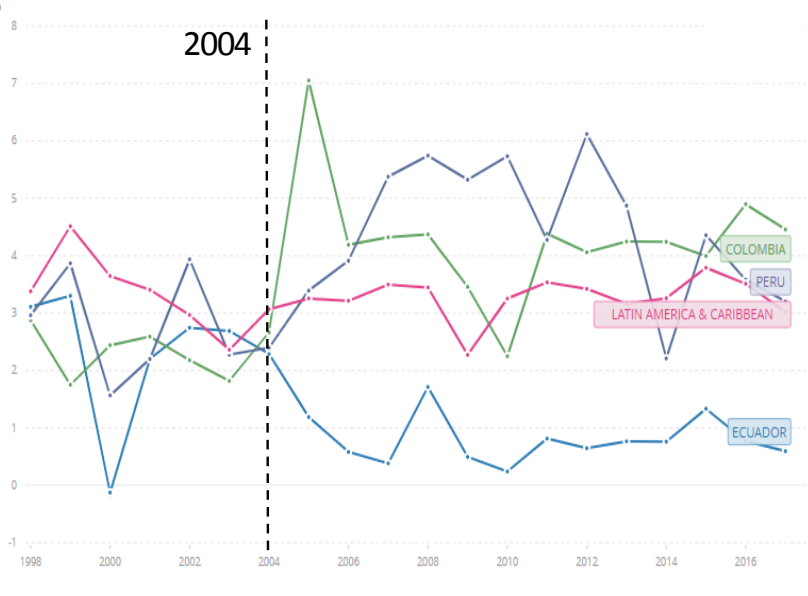

Note: This figure shows the flows of FDI (as a share of GDP) received by Colombia, Peru, Ecuador, and the region.

Source: Authors' calculation using information from the World Development Indicators.
Figure 17: Stock of FDI (\$ millions)

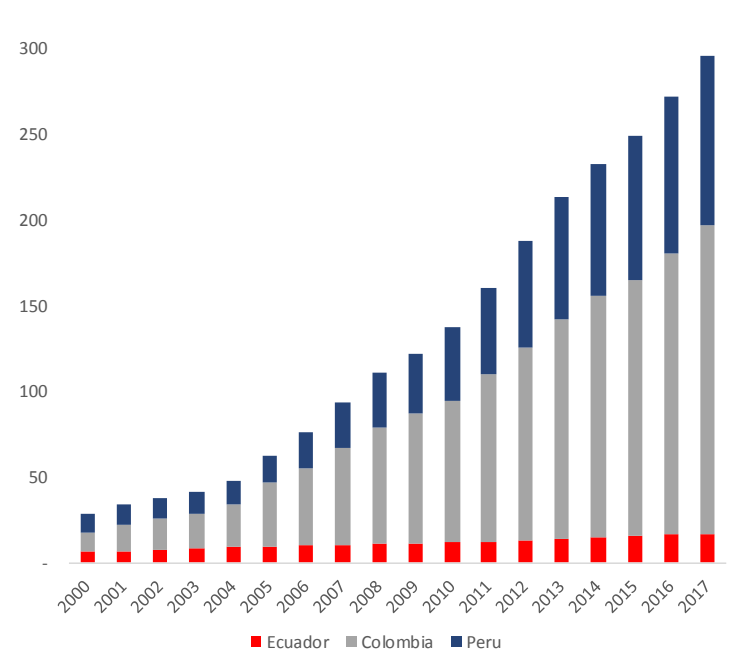

Note: This figure shows the stock of FDI in \$ millions in Ecuador, Peru, and Colombia.

Source: Authors' calculation using information from the World Development Indicators.

The low level of FDI in Ecuador over the last decade reflects the government's decision to pursue economic growth through public spending and investment, rather than through a private-sector led growth model. High international oil prices provided the government with the ammunition to pursue expansionary fiscal measures, while at the same time increasing regulations and controls over the economy. Before 2007, private investment comprised the driver of capital formation in the country (Figure 18). Afterwards, the gap between gross fixed capital formation and gross fixed capital formation by the private sector started to widen, indicating that public investment was crowding out private investment. In this same vein, FDI as a percentage of gross fixed capital formation fell from 13.3 percent to 2.3 percent between 2002 and 2017. 


\section{Figure 18: Gross Fixed Capital Formation in Ecuador}

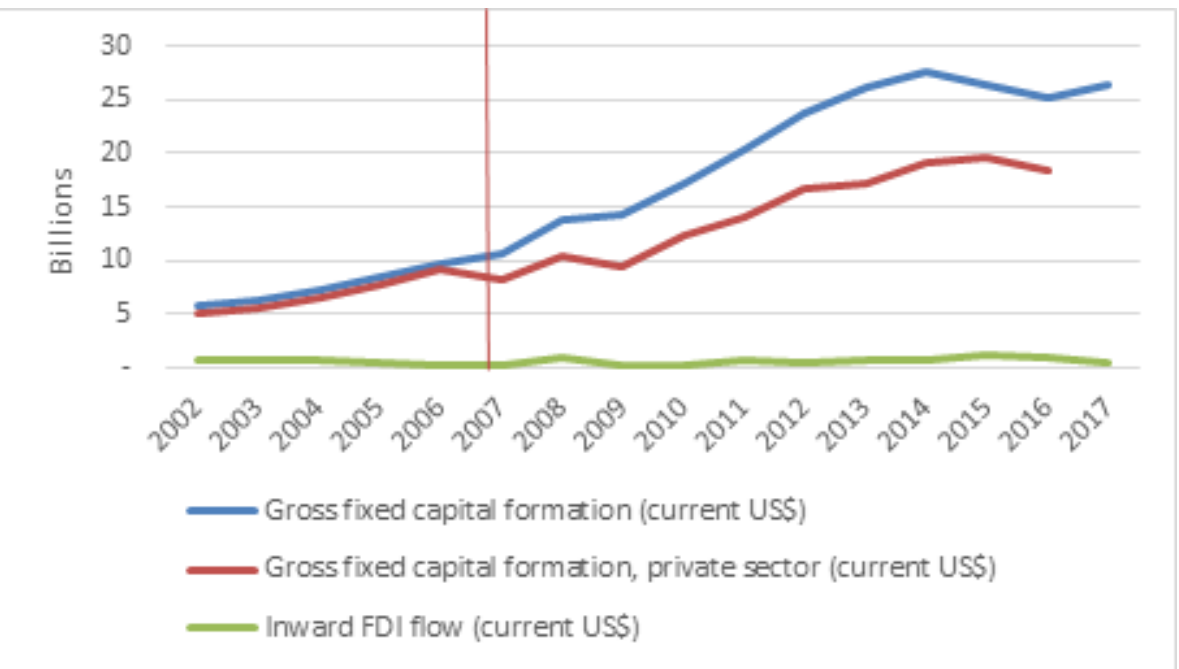

Note: This figure shows the evolution of gross fixed capital formation and FDI in Ecuador. Source: Authors' calculation using the World Bank's World Development Indicators.

During the last decade, the main sources of FDI in Ecuador switched from Brazil and the US to China, Europe, and Venezuela. Between 2002-2006, 82.6 percent of net FDI flows originated from the Americas. The main source of net FDI flows was Brazil, with 26.7 percent of the total. Second was the United States, with 7.2 percent. ${ }^{9}$ From 2007 to 2017, European FDI increased to 33.9 percent. FDI from the Netherlands and Spain rose particularly noticeably, increasing from 1.6 percent to 12.2 percent and from 0.5 percent to 11.2 percent, respectively. Chinese investors also gained interest in Ecuador during this period, with their share of FDI flows increasing from 0.6 percent in 2007 to 11.7 percent in 2017. Venezuelan investments in Ecuador showed a similar trajectory, rising from 0.4 percent of total flows in the period 2002-2006 to 9.3 percent in 2018 . The United States shows the largest decrease in FDI, implying a sustained disinvestment by American multinationals during the last decade (Table 6).

\footnotetext{
${ }^{9}$ Several Caribbean tax havens - notably, Cayman Islands, Panama, and the Bahamas - were also important. The identification of the nationality of the ultimate investors who use these countries as platforms to invest is unfeasible with the information at hand.
} 


\section{Table 6: FDI Flows by Source Country}

\begin{tabular}{|c|c|c|c|c|c|c|}
\hline Region / Country & Total 2002-2006 & Total 2007-2017 & $2018^{*}$ & Share 2002-2006 & Share 2007-2017 & Share 2018 \\
\hline ANDEAN COMMUNITY & $66,456.98$ & $619,956.93$ & $81,964.63$ & $2.0 \%$ & $8.7 \%$ & $11.1 \%$ \\
\hline Colombia & $46,748.86$ & $161,159.54$ & $6,620.78$ & $1.4 \%$ & $2.3 \%$ & $0.9 \%$ \\
\hline Peru & $5,396.54$ & $284,898.11$ & $7,261.47$ & $0.2 \%$ & $4.0 \%$ & $1.0 \%$ \\
\hline Venezuela & $13,356.64$ & $175,569.48$ & $68,081.39$ & 0.486 & $2.5 \%$ & $9.3 \%$ \\
\hline REST OF AMERICA & $2,626,123.10$ & $2,923,688.91$ & $330,017.51$ & $80.6 \%$ & $40.9 \%$ & $44.9 \%$ \\
\hline Brazil & $869,734.12$ & $167,310.16$ & 11.67 & $26.7 \%$ & $2.3 \%$ & $0.0 \%$ \\
\hline Cayman Islands & $462,661.78$ & $(459,981.95)$ & 15.84 & $14.2 \%$ & $-6.4 \%$ & $0.0 \%$ \\
\hline Panama & $360,927.51$ & $602,114.30$ & $2,860.02$ & $11.1 \%$ & $8.4 \%$ & $0.4 \%$ \\
\hline United States & $235,143.70$ & $(654,946.18)$ & $22,042.12$ & $7.2 \%$ & $-9.2 \%$ & $3.0 \%$ \\
\hline Mexico & $55,404.97$ & $1,436,448.67$ & $61,078.72$ & $1.7 \%$ & $20.1 \%$ & $8.3 \%$ \\
\hline Canada & $69,826.73$ & $811,932.90$ & $92,001.67$ & $2.1 \%$ & $11.4 \% 6$ & $12.5 \%$ \\
\hline Uruguay & $27,020.86$ & $283,056.77$ & $88,405.84$ & $0.8 \%$ & $4.0 \%$ & $12.0 \%$ \\
\hline EUROPE & $474,807.10$ & $2,420,825.58$ & $293,652.18$ & $14.6 \%$ & $33.9 \%$ & $39.9 \%$ \\
\hline France & $176,426.30$ & $71,395.36$ & $5,043.05$ & 5.486 & $1.0 \%$ & $0.7 \%$ \\
\hline Great Britain & $85,665.06$ & $148,450.17$ & $6,815.99$ & $2.6 \%$ & 2.196 & $0.9 \%$ \\
\hline Netherlands & $53,636.66$ & $874,990.53$ & $162,361.56$ & $1.6 \%$ & $12.2 \%$ & $22.1 \%$ \\
\hline Spa in & $14,722.09$ & $803,109.25$ & $84,845.76$ & $0.5 \%$ & $11.2 \%$ & $11.5 \%$ \\
\hline ASIA & $55,621.30$ & $908,243.67$ & $45,736.45$ & $1.7 \%$ & $12.7 \%$ & $6.2 \%$ \\
\hline China & $19,773.97$ & $834,419.03$ & $41,833.00$ & $0.6 \%$ & $11.7 \%$ & $5.7 \%$ \\
\hline OTHER & $33,548.22$ & $272,109.10$ & $(15,626.71)$ & $1.0 \%$ & $3.8 \%$ & $-2.1 \%$ \\
\hline TOTAL & $3,256,556.71$ & $7,144,824.19$ & $735,744.06$ & $100.0 \%$ & $100.0 \%$ & $100.0 \%$ \\
\hline Selected & $2,496,445.80$ & $5,539,926.13$ & $649,278.87$ & $76.7 \%$ & $77.5 \%$ & $88.2 \%$ \\
\hline
\end{tabular}

Note: This table presents the average FDI flows in Ecuador by main source countries for the average period of 2002-2006 and 2007-2007. Preliminary information for 2018 is also presented. Values are in \$ millions.

A negative FDI flow indicate a disinvestment in the country.

Source: Authors' computation based on information for the Ecuador Central Bank.

Natural-seeking FDI is the main motivation for foreign investors in Ecuador. ${ }^{10}$ The share of FDI inflows destined for the mining sector increased from 33.9 percent in the period 2002-2006 to 38.3 percent during 2007-2017. In 2018, they reached 40.2 percent. The sectoral composition of FDI has changed substantially in the last 15 years. Between 2002-2006, over half (55.3 percent) of total FDI derived from logistics and communications, manufacturing, retail and wholesale, and business services. Between 2007-2017, manufacturing increased in significance, comprising 21.2 percent of FDI, placing the sector second behind mining. Retail and wholesale also received 21.2 percent, while business services and agriculture received 16.7 percent and 6.3 percent, respectively. In the first three trimesters of 2018, Ecuador's business services sector attracted substantially more FDI; the most recent data put its contribution at 20.2 percent of net FDI flows.

\footnotetext{
10 The motivations that investors have for entering developing countries can broadly be categorized as follows: (i) natural resource-seeking investment, which describes a situation where a foreign investor establishes an enterprise in the host country to access natural resources; (ii) market-seeking investment, which is driven by the foreign investor's intention to primarily serve the host country's market; and (iii) efficiency-seeking investment, in which the investor chooses a host country in order to take advantage of some competitive factor, such as a labor force, utilities, services, or geographic location to maximize production efficiency. See: Dunning 1993.
} 
While foreign firms accounted for only 9.3 percent of the universe of formal enterprises in Ecuador, they generated 43.2 percent of the total value added in the economy in 2017. Using information from the financial statements of all formal enterprises, we depict the distinctive nature of multinational corporations operating in Ecuador with respect to local firms. ${ }^{11}$ Table 7 shows the distribution of firms and value added for 2017 across different sectors. The three economic sectors with the largest number of formal firms are: wholesale and retail (23.3 percent); professional, transportation, and storage (14.4 percent); and scientific and technical services (11.8 percent). The highest concentration of foreign firms is in the mining sector, where 22.2 percent of firms are foreign-owned enterprises. The utilities industry is also highly represented by foreign firms, which comprise 15.3 percent of all firms in the sector. The balance is similar in the hospitality services industry, at 13.9 percent. The sectors that produced the highest value added in 2017 were wholesale and retail (26.5 percent), manufacturing ( 25.7 percent), and mining ( 8.4 percent). The sectors in which foreign-owned firms generated the highest share of value-added comprised ICT (69 percent), mining (64.6 percent), and manufacturing (51.7 percent).

\section{Multinational corporations operating in Ecuador have significantly better outcomes compared to local firms with respect to productivity, sales, investment, and connections to international markets. A simple exercise to estimate the markup of foreign firms around these dimensions is presented in Appendix 1. The results indicate that foreign-owned firms were on average 4 percent more productive than domestic firms between 2004-2017. During this period, they also generated 11 percent more value added and were responsible for 65 percent more investment. Foreign firms also exported 126.6 percent more than domestic firms and imported 386.5 percent more, during this same period. In fact, most exporter-importer firms are foreign- owned enterprises.}

\footnotetext{
${ }^{11}$ We used financial statement information form the universe of formal firms provided by the Ecuadorian Business Register Agency (Superintendencia de Compañías). To identify foreign-owned firms, we combined this information with capital registry and capital flow information, which is also provided by the agency. A firm is identified as 'foreign-owned' when at least one tenth of its shares is held by a foreign entity. The financial statement information is available for all companies that filed tax returns with the tax authority. State-owned enterprises are excluded from the sample, as are companies in the financial sector.
} 
Table 7: Distribution of Firms and Value Added by Economic Sector (2017)

\begin{tabular}{|c|c|c|c|c|c|c|c|}
\hline \multirow[b]{2}{*}{ ciiu4 } & \multirow[b]{2}{*}{ Description } & \multicolumn{3}{|c|}{ numer of companies } & \multicolumn{3}{|c|}{ value a dded } \\
\hline & & \# & $\%$ of total & $\%$ foreign & USD millions & $\%$ of total & $\%$ foreign \\
\hline A & Agriculture, forestry and fishing & 3,332 & 6.496 & $12.3 \%$ & $2,067.69$ & 8.086 & $37.3 \%$ \\
\hline B & Mining and quamying & 544 & $1.0 \$ 6$ & 22.296 & $2,185.46$ & 8.486 & $64.6 \% 6$ \\
\hline C & Manufacturing & 4,205 & 8.196 & 12.996 & $6,683.39$ & $25.7 \%$ & $51.7 \%$ \\
\hline D & Electricity, gas, steam and air conditioning supply & 209 & $0.4 \%$ & $15.3 \%$ & 73.89 & $0.3 \%$ & $18.4 \%$ \\
\hline E & Water supply, sewerage, waste management & 227 & 0.486 & $7.5 \% 6$ & 194.02 & 0.796 & $7.0 \%$ \\
\hline $\mathrm{F}$ & Construction & 3,850 & 7.496 & 4.196 & $1,048.38$ & 4.086 & $12.9 \%$ \\
\hline G & Wholesale and retail trade & 12,078 & 23.336 & 11.986 & $6,896.55$ & 26.596 & $41.3 \% 6$ \\
\hline $\mathrm{H}$ & Transportation and storage & 7,359 & 14.296 & 3.486 & $1,155.81$ & 4.486 & $45.9 \%$ \\
\hline 1 & Accommodation and food service activities & 1,105 & 2.196 & 13.996 & 409.98 & $1.6 \% 6$ & $28.0 \% 6$ \\
\hline J & Information and communication & 2,173 & $4.2 \%$ & 12.196 & $1,534.43$ & $5.9 \%$ & $69.0 \% 6$ \\
\hline K & Financial and insurance activities & 1,147 & $2.2 \%$ & 13.796 & 390.34 & $1.5 \%$ & $33.6 \%$ \\
\hline$L$ & Real estate activities & 3,936 & $7.6 \%$ & 9.996 & 310.36 & 1.266 & 39.796 \\
\hline M & Professional, scientific and technical activities & 6,136 & 11.886 & 8.296 & 998.39 & 3.886 & 25.096 \\
\hline N & Administrative and support service activities & 3,457 & $6.7 \%$ & 6.996 & $1,150.70$ & 4.486 & 14.796 \\
\hline 0 & Public administration and defence & 11 & $0.0 \% 6$ & 9.196 & 1.11 & 0.086 & 1.996 \\
\hline P & Education & 678 & 1.396 & 7.196 & 244.89 & 0.966 & 19.496 \\
\hline$Q$ & Human health and social work activities & 959 & $1.8 \%$ & 7.266 & 474.49 & 1.896 & 23.056 \\
\hline$R$ & Arts, entertainment and recreation & 232 & 0.486 & 11.676 & 26.06 & 0.196 & $19.8 \% 6$ \\
\hline S & Other service activities & 293 & $0.6 \%$ & 9.266 & 135.38 & $0.5 \%$ & $28.0 \% 6$ \\
\hline $\mathrm{T}$ & Activities of households as employers & 3 & $0.0 \% 6$ & 0.086 & 0.03 & 0.086 & $0.0 \%$ \\
\hline $\mathrm{U}$ & Activities of extraterritorial organizations and bodies & 1 & 0.096 & 0.056 & 0.04 & 0.086 & 0.086 \\
\hline Total & Total & 51,935 & $100 \%$ & $9.3 \%$ & $25,981.38$ & $100.0 \%$ & $43.2 \%$ \\
\hline
\end{tabular}

Note: This table shows the number of companies that were formally established in Ecuador in 2017, by economic sector and ownership.

Source: Authors' computation based on information for the Superintendencia de Compañías.

Figure 19: Performance of Foreign Firms versus Domestic Firms (2004-2017)

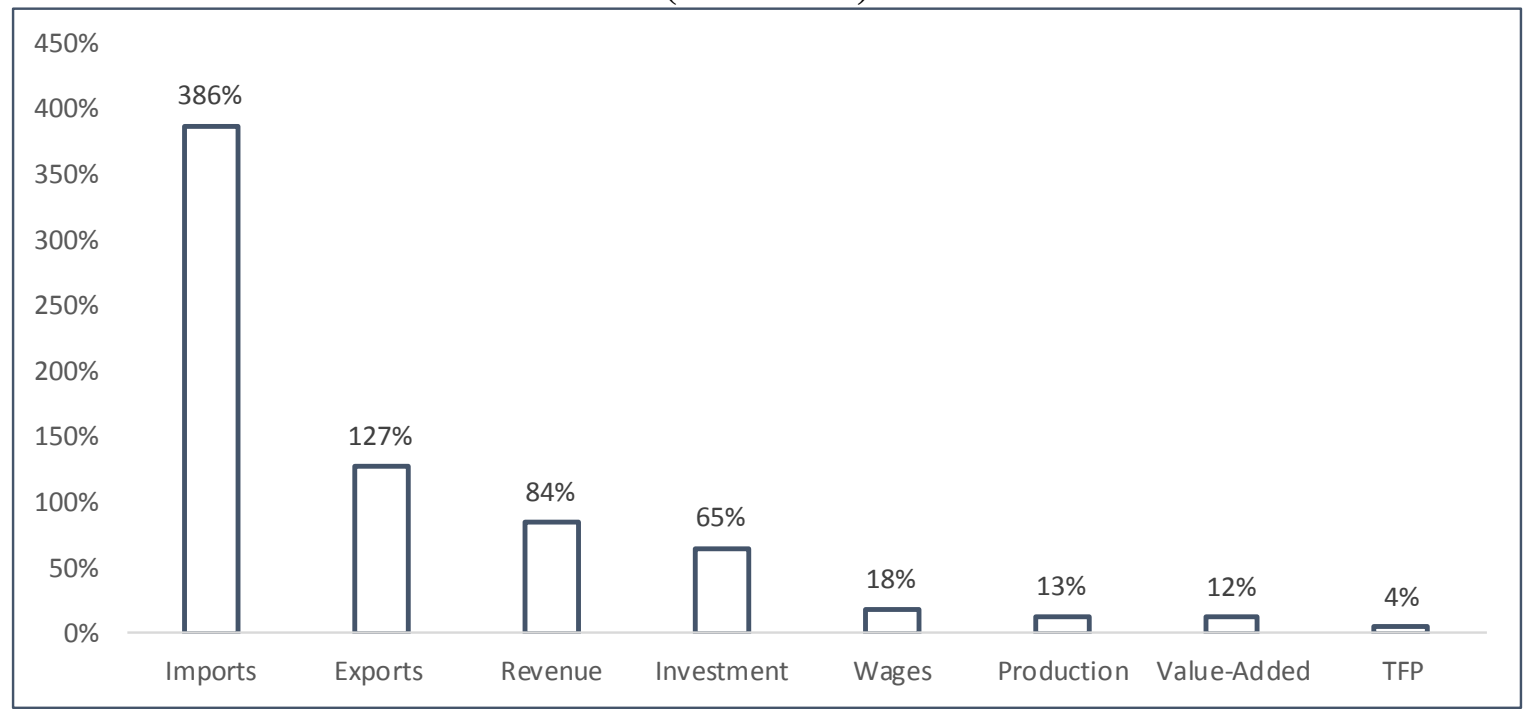

Note: This figure reports the coefficients of a regression to estimate the different performance of foreign firms compared to domestic firms in Ecuador for the period 2004-2017. All estimates are statistically significant at the 5-percent level. The identification strategy and regression results are presented in the Appendix.

Source: Authors' calculation using information from the Ecuadorian Business Registrar Office. 


\subsection{Trade in Value Added and Global Value Chains}

The rise of global value chains (GVCs) represents one of the most important transformations in global trade and investment of the last decades. Once concentrated among a few large economies, global flows of goods, services, and capital now reach many developing economies. This so-called "second unbundling" of globalization (Baldwin and Lopez-Gonzalez 2013) is driving a deep transformation in global trade and investment flows, as evinced by the rise of GVCs. The most important factor driving the increase in GVC trade is the fall in transport costs. This has occurred thanks to a variety of innovations, including: containerization; the ICT revolution; lower trade costs due to reduced global tariffs and the proliferation of bilateral and regional trade and investment agreements; the transition of China to a market economy and its export-led growth strategy; and trends in global business to outsource 'non-core' business functions, coupled with a drive to cut the cost of goods produced for export and for home markets.

One of the major implications of the growth of trade in fragmented global production networks is the inflation of aggregate export figures. This results from the double and triple counting of intermediates as they cross over national borders in the extended production process. For example, a Korean semiconductor feeding into an iPad will be counted as a Korean export when it is shipped to Thailand to be assembled into an internal drive, then as a Thai export when the drive is shipped to China for final assembly, and finally as a Chinese export when the finished iPad is shipped to its destination market for sale. Understanding a country's gross exports, as well as its exports of domestic value added, therefore helps assess a country's competitiveness. What matters ultimately for a country's economic growth is not gross exports (which may include a significant share of foreign value added via imported inputs), but the domestic value added (DVA) embodied in gross exports. Box 3 exemplifies the decomposition of gross exports into its different components.

\section{Box 3. From Gross Exports to Domestic Value Added}

To exemplify the decomposition of gross exports of a given product into domestic and foreign value added, we employ the auto sector as an example. Nowadays, automobiles are assembled in a few global locations, but their parts and components are produced in many countries prior to the assembly stage. Taking the export value of an assembled car as a reflection of the country's economic capacity would therefore be misleading. The export value of the car can be broken down as follows:

i. $\quad$ Value added created in the auto industry (direct domestic value added).

ii. Value added created in other sectors supplying the auto industry (indirect domestic value added).

iii. Value added re-imported intermediates (which have been previously exported).

iv. Value added imported from abroad in terms of both intermediate inputs and services (foreign value added). 


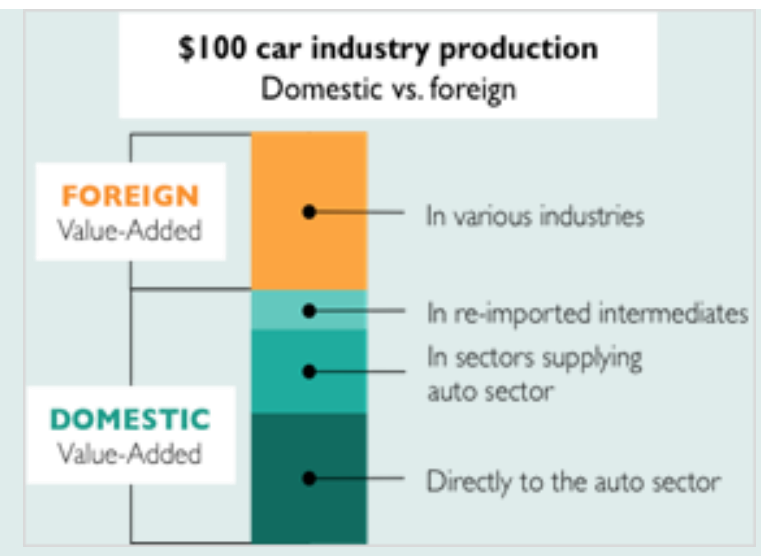

A country's ability to benefit from GVCs is best shown by the evolution of its DVA embodied in gross exports over time. In simple terms, an increase in the DVA embodied in gross exports over time signifies greater value addition within the country itself. As a function of productivity, it is associated with the breadth, variety, and sophistication of the tasks and activities that occur within the given country (Taglioni and Winkler 2014a).

While greater DVA means that the country participates more in GVCs, a country's policy objective should not be to maximize DVA. This is particularly the case when DVA is achieved through an import substitution strategy that results in low-quality final products (Engel, Winkler, and Farole 2015).

\section{Ecuador shows one of the highest percentages of DVA embedded in gross exports in the region, a reflection of its policy between 2010-2015 to encourage the substitution of imports} for local production during 2010-2015. In 2015 (the last year for which data is available), 88.2 percent of the value added of Ecuadorian exports was generated domestically (Figure 20). The DVA embedded in exports is similar to that of Colombia and Peru, and much higher than that in Uruguay, Chile, and Mexico. Ecuador also shows the highest rates of DVA growth between 2005 and 2015 - a phenomenon linked, in part, to the import substitution policy at play during the latter part of this period (Figure 21). In fact, at 91 percent, manufacturing posts the second largest DVA level of any export sector in Ecuador. It is only tipped by agriculture, at 98 percent. The average DVA in exports in the manufacturing sector for Ecuador's peer countries is 85 percent. $^{12} 13$

\footnotetext{
12 Although Ecuador shows one of the highest percentages of DVA embedded in gross exports among comparators, these comparisons could be driven by an export composition effect. This arises when some comparator countries specialize in sectors that are more likely to belong to GVCs. As a result, they are more likely to use imported intermediate inputs (e.g. electronics) than others (e.g. oil).

${ }^{13}$ Information about trade in value added is derived from multi-country input-output tables, so it is updated less regularly than information about gross exports. We employ the Eora database to investigate Ecuador trade in value added. See: Lensen et al. 2013.
} 
Figure 20: Domestic Value Added as share of Gross Exports $(\%, 2015)$

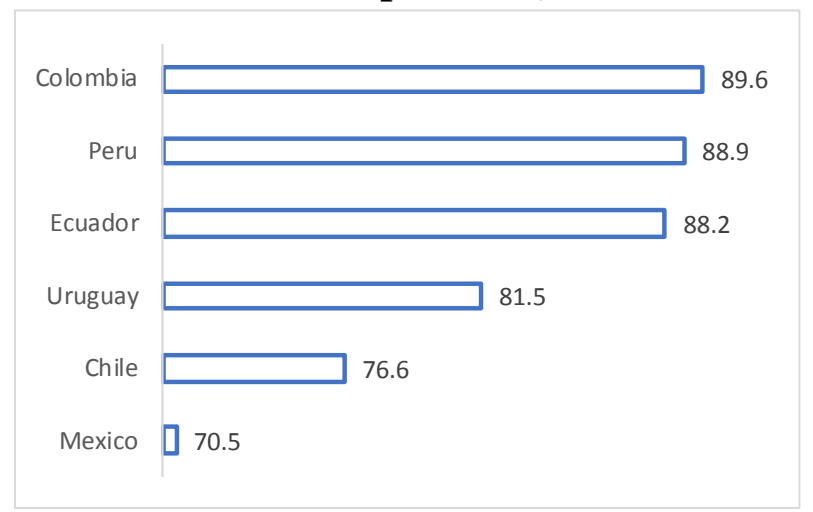

Note: This figure shows the DVA as a share of gross exports.

Source: Authors' calculation using EORA database.
Figure 21: Changes in Domestic Value Added in Exports (\%, 2005-2015)

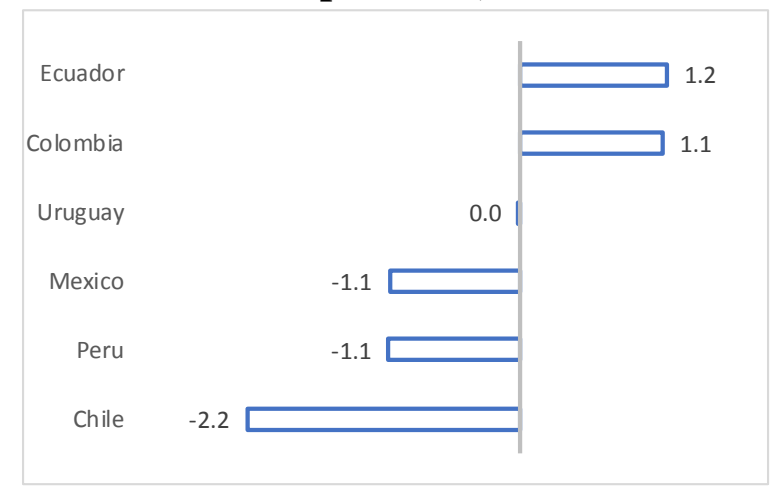

Note: This figure shows the changes in the DVA between 2005 and 2015.

Source: Authors' calculation using the EOURA database

Compared to its regional peers, Ecuadorian firms are situated in the middle range of GVC participation. In addition to the DVA embedded in gross exports, the connection of a country with global GVCs can be gauged in two other ways: namely, by the share of foreign value added embodied in exports ('backward linkages'); and the share of its value added embodied in other countries' exports ('forward linkages'). The GVC Participation Index combines these two measures to provide an indication of the country's participation in vertically integrated production (Koopman et al. 2010). A country's participation value increases in line with foreign value added in gross exports and with the value of inputs exported to third countries and used in their exports. ${ }^{14}$ The GVC Participation Index for the region indicates that Chile is most connected to GVCs, followed by Peru and Mexico. Ecuador comes fourth (Figure 22).

\footnotetext{
${ }^{14}$ The index is formally constructed as $G V C_{\text {participation }}=\frac{F V A+D V X}{\text { Gross Exports }}$, where FVA is the foreign value-add in the country's gross exports (backward linkages) and DVX is the share of the country's value added in other countries' gross exports (forward linkages).
} 
Figure 22: GVC Participation Index (2015)

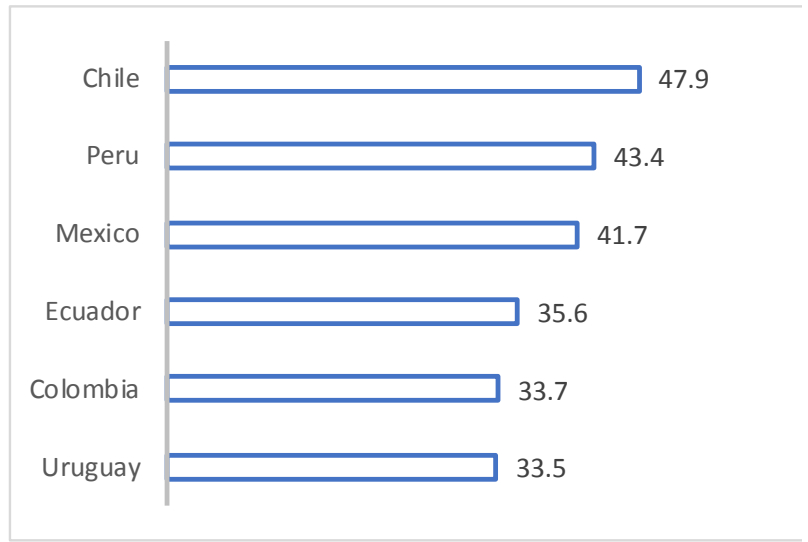

Note: This figure reports the GVC participation index as proposed by Koopman et al. 2010.
Figure 23: GVC Export Upstreamness

(2015)

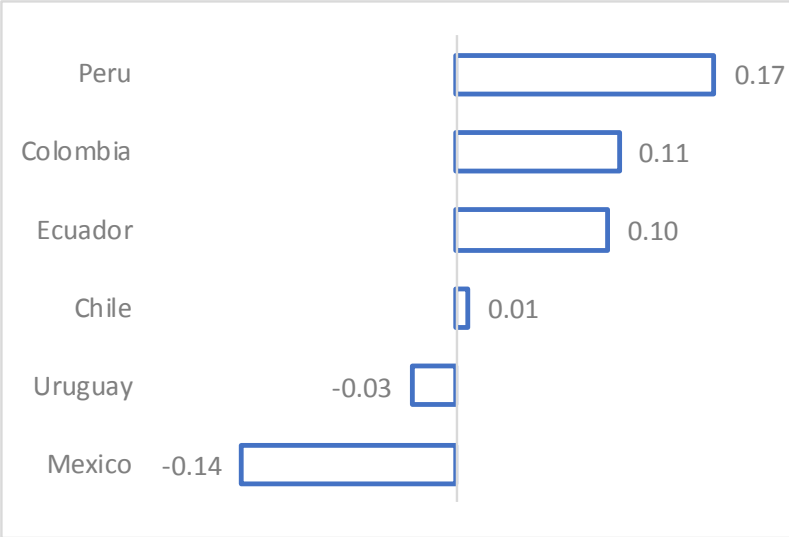

Note: This figure reports the GVC export upstreamness as proposed by Antras et al. 2012.

Source: Authors' calculation using the EORA database. Source: Authors' calculation using the EORA database.

Ecuador is located upstream in the GVCs in which it participates, indicating that the country's specialization concentrates on primary goods with low value added. The position of a country in GVCs can be measured by its "upstreamness" or its "distance to final demand". Distance here is measured with respect to the number of production stages between the production of a given good/component in a given country and the location of the final demand (Antràs at al. 2012). ${ }^{15}$ For some value chains, such as agriculture, value is created primarily downstream. Given the importance of primary products in its export basket, Ecuador is located relatively far from final demand (Figure 23). The same is true for Peru and Chile. In other words, these countries contribute more value added to other countries exports than other countries contribute to theirs. Mexico, on the other hand, is close to the final demand due to its deep integration with the United States.

\subsection{Key Challenges in Integrating with the Global Economy}

The evaluation of Ecuador's connection to international markets identifies key challenges that the country faces in the process of reconnecting with the global economy. These constraints are the outcomes of the international environment over the last decade as well as Ecuador's own growth model during this period. Table 8 presents the key constrains identified in each one of the competitiveness channels discussed in this section.

15 The index is formally constructed as $G V C_{\text {Upstreamness }}=\ln \left(1+\frac{D V X}{\text { Gross Exports }}\right)-\ln \left(1+\frac{F V A}{\text { Gross Exports }}\right)$, where FVA is the foreign value-add in the country's gross exports (backward linkages) and DVX is the share of the country's value added in other countries' gross exports (forward linkages). 


\section{Table 8: Competitiveness Challenges for Global Integration in Ecuador}

\section{Channels}

Exports

Imports

Foreign Direct

Investment

Global Value Chains

\section{Key Challenges}

1. High concentration of exports around a few products with low value added that makes the country vulnerable to abrupt changes in international prices.

2. Disproportionally high fixed costs to export, as evinced by the small number of exporters, the low entry rates, and the relatively larger size of exporters upon entry.

3. Barriers to growth for medium-size exporters due to high variable costs to export, as indicated by the low concentration of export value across exporters.

4. Absence of wage differences between exporters and non-exporters, despite the former showing better outcomes in terms of size, investment, and productivity - a phenomenon that contradicts international evidence and indicates important friction in the labor market.

1. During the last decade, import performance has broadly followed the oil price cycle. Changes in imports responded to government interventions to maintain a low trade deficit rather than reacting to market forces.

2. Imports of capital products, which are important for increasing the productivity of local firms, are relatively low.

1. The country has lost competitiveness in attracting FDI over the last decade. Between 2005-2015, annual flows typically accounted for less than 1 percent of GDP. This fact reflects a growth model based on public expenditure that crowded out private investment.

2. A sustained disinvestment of U.S. multinational corporations operating in the country over the period 2005-2015 contributed to the reduction of the stock of FDI.

3. FDI is mostly targeted at the natural resources sector. Investments directed towards the domestic market or towards GVC connections (efficiency-seeking FDI) are minor.

1. The share of domestic value added in gross exports grew during 2005-2015 and is currently one of the highest in the region. This fact may reflect Ecuadorian firms' difficulty in joining GVCs due to the country's import substitution policy.

2. The degree of Ecuador's participation is below that of Chile, Peru, and Mexico.

3. Ecuador is located upstream in the GVCs in which it participates, indicating the country's specialization in primary products. 


\section{Competitiveness Diagnostic}

This section starts by discussing key drivers that are important for increasing the international competitiveness of Ecuador and then suggests policy recommendations to overcome the challenges identified in the previous section. Based on the analytical work presented in the previous section, in conjunction with qualitatively information obtained through field interviews, we suggest four policy areas that are important to foster the competitiveness of Ecuadorian firms. These four areas focus on reducing the internal and external costs of connecting to global markets. They comprise: (i) Ecuador's institutional framework for trade and investment policy and promotion; (ii) its standpoint regarding trade policy, both with respect to preferential agreements with neighboring countries (such as the Pacific Alliance) and unilateral protectionism polies; (iii) the flexibility of the country's labor market; and (iv) its agricultural support policies.

\subsection{Institutional Framework for Trade and Investment Policy and Promotion}

The quality of the institutional framework for trade and investment has a direct effect on the coherence of policy direction, formulation, and implementation, as well as an indirect effect on policy outcomes. For any country looking to successfully integrate into global markets, therefore, an institutional arrangement that is aligned, well-coordinated, and effective is essential. To arrive at this point requires clear vision, commitment, and action-oriented leadership on the part of the government. When such conditions are in place, it is then possible to convert a set of government agencies into an articulate and high-performing institutional cluster that is capable of leveraging international trade and FDI in order to foster economic growth and diversification.

The recent reorganization and consolidation of government ministries working in the areas of production, trade, and investment make an institutional diagnostic timely. This section of the report provides preliminary recommendations about how improvements might be made to the different functions of trade and investment-related policy making and promotion, as well as interinstitutional coordination.

\section{a. Ecuador's Institutional Framework for Trade and Investment Policy and Promotion}

Ecuador has recently undergone structural modifications to the institutional framework governing its foreign trade and FDI. A reshuffling of functions and institutional changes in the foreign trade and investment landscape has been frequent over the last decade. However, a major departure from previous practice occurred in September 2018 with the creation of an umbrella ministry - the Ministry of Production, Foreign Trade, Investment and Fisheries.

The Ministry of Production, Foreign Trade, Investment and Fisheries was formed from the consolidation of three different ministries and one decentralized institution. These comprise the Ministry of Industries and Productivity (Ministerio de Industrias y Productividad), the Ministry 
of Foreign Trade and Investment (Ministerio de Comercio Exterior e Inversiones), the Ministry of Aquaculture and Fisheries (Ministerio de Acuacultura y Pesca), and the Institute for the Promotion of Exports and Investments (Instituto para la Promoción de Exportaciones e Inversión, also known as ProEcuador). The new ministry has four vice-ministries that have been assigned to address the organization's different functions::

- Vice-ministry of Production and Industry (Viceministerio de Produccion $e$ Industrias)

- Vice-ministry of Foreign Trade (Viceministerio de Comercio Exterior)

- Vice-ministry of Export and Investment Promotion (Viceministerio de Promoción de Exportaciones e Inversiones)

- Vice-ministry of Aquaculture and Fisheries (Viceministerio de Acuacultura y Pesca)

Each of these vice-ministries have similar roles and responsibilities as the entities that they replaced. The main difference is that some directorates and back office functions have been subsumed and have fused into a single entity for efficiency purposes. In principle, this ministerial structure should facilitate enhanced internal coordination, collaboration, and synergies. It remains too early to assess if this is the case, however. The four vice-ministries are still grappling with the implications of the consolidation process on their respective mandates and functions. For now, they appear to be operating as independent agencies. A preliminary organigram of the ministry is presented in Figure 24.

The Vice-Ministry of Foreign Trade carries out the executive leadership role of trade policy formulation, as well as representing the country in foreign trade matters. This leadership role involves negotiating trade agreements. Previously, these executive responsibilities sat with the Ministry of Foreign Affairs. To confuse matters slightly, the Ministry of Foreign Affairs is still tasked with negotiating and signing up to bilateral investment treaties. Coordination between the two ministerial entities occurs under inter-ministerial councils, such as the Committee for International Trade (COMEX) and the Strategic Committee for the Promotion and Attraction of Investments (CEPAI), as described in more depth below.

Broad and comprehensive functions within the scope of foreign trade lie under the ViceMinistry of Foreign Trade. The scope of the Directorate of Trade Defense under this viceministry includes the imposition of trade remedies, such as antidumping and countervailing duties. It also includes leading Ecuador's representation in trade disputes. Trade facilitation and export competitiveness appear on its list of responsibilities as well. Finally, the vice-ministry is mandated with overseeing the origin certification and supervision process.

The former Institute for Export and Investment Promotion (ProEcuador) is currently the Vice-Ministry of Export and Investment Promotion. Formerly a decentralized agency, ProEcuador used to have much more independence and a larger budget. Now, as part of the newly 
formed vice-ministry, it has ceded responsibility for the promotion exports and investments to two separate sub-secretariats - the Sub-secretariat for Export Promotion and the Sub-secretariat for Investment Promotion.

Figure 24: Organigram and Structure of the Ministry of Production, Foreign Trade, Investment, and Fisheries

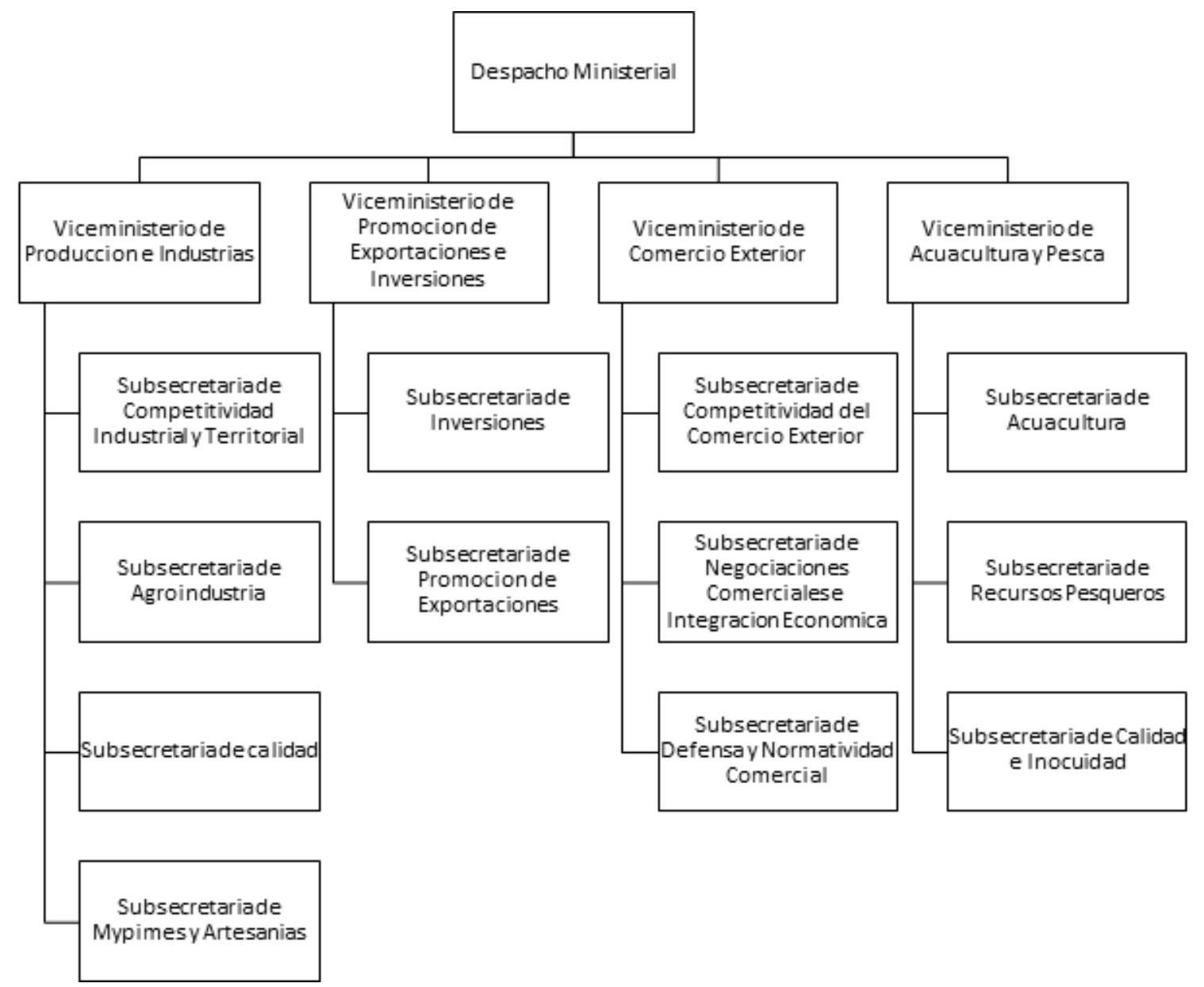

Source: The Ministry of Production, Foreign Trade, Investment, and Fisheries

Export and investment promotion functions in Ecuador have been carried out by different entities over the last two decades, with varying degrees of prioritization. A private, nongovernmental entity - the Export and Investment Promotion Corporation (CORPEI) - began carrying out export promotion functions back in 1998, financed by tax revenue generated from exports. At the end of 2010, the government decided to establish ProEcuador as a decentralized agency, with the functions of both an export and investment promotion agency. In practice, however, the new agency mostly focused on supporting exporters. Other programs and initiatives were created on an ad hoc basis by different ministries around the same time, such as InvestEcuador. It was against this institutional backdrop that ProEcuador became subsumed within the Vice-Ministry of Export and Investment Promotion. 
The Sub-Secretariat for Export Promotion seems to operate with less autonomy and with more budgetary restrictions than in the past. Consequently, its export promotion activities are being redefined, as are the services it used to provide to exporters. In addition, it appears that some of the studies and diagnostics on export potential and competitiveness that it used to carry out are now falling under the scope of work of other vice-ministries. Lack of communication and coordination amongst these new agencies represents a major challenge.

\section{The Sub-Secretariat for Investment Promotion plays a role in policy making, regulation, and investment promotion. Its work has so far concentrated primarily on approving and administering investment contracts. Tax incentives granted to investors under such contracts have been recently enhanced by the new Organic Law for Productive Promotion, Investment Attraction, Employment Generation, and Fiscal Stability and Balance, approved in late 2018 (Box 4). The role of investment promotion - namely, attracting FDI and providing support services to foreign investors - seems weak. This is as true for the new umbrella ministry as it is for the Sub-Secretariat for Investment Promotion (despite the latter having precisely this mandate)}

\section{Box 4. Investment Promotion Policies in Ecuador}

In 2010, the government issued the Organic Code of Production, Commerce and Investments (COPCI), which regulated investment contracts and replaced Ecuador's existing investment treaties. In 2011, the government approved the Regulation on the Structure and Institutionalization of Productive Development Mechanisms and Instruments. These new rules aimed to meet the needs of both the state and investors. For the state, its role was to ensure that investments generate tangible development benefits for Ecuador. For investors, it sought to ensure that their resources are focused effectively and their investments are maintained over a prolonged period. In December 2015, the Organic Law of Incentives for Public-Private Partnerships and Foreign Investment (APP incentives act) was approved as a complement to the COPCI and an incentive for foreign investment.

In August 2018, President Lenin Moreno passed the new Organic Law for Productive Promotion, Investment Attraction, Employment Generation, and Fiscal Stability and Balance. This new legislation introduced substantial amendments to a number of laws. These include, among others: the Organic Domestic Tax Regime Law; the Organic Monetary and Finance Code; the Law for an Economic Reboot, Greater Dollarization and Financial Management Update Law; and the Companies Act. Some of the most relevant measures for foreign investment covered in the new legislation include the following:

- New investments from new and existing companies in strategic sectors in areas outside of Quito and Guayaquil are exempt from paying income tax and its corresponding estimated tax for 12 years; those in the urban areas of Quito and Guayaquil are exempt for eight years. There are 15 strategic sectors including; agriculture and food processing, forestry, metalwork, petrochemicals, pharmaceuticals, tourism, renewable energy, energy efficiency, logistic services, biotechnology, export of services, software and hardware development, sustainable construction materials, and manufacturing.

- New investments from all companies in basic industries receive an exemption from income tax and its corresponding estimated tax for 15 years. Basic industries are defined as copper and/or aluminum smelting and refinery, steel foundry, hydrocarbon refinery, petrochemicals, cellulose, and ship construction for the navy. 
- For the purpose of dividends' distribution, international transactions are exempt from ISD tax as long as half a company's profits are reinvested. Such dividends are exempted from Income Tax.

- Zero-percent IVA tax is imposed on raw materials and supplies that are imported or purchased in the local market for the agriculture, livestock, aquaculture, or fishing industries. Similarly, machinery and spare parts for the agriculture, aquaculture, and fishing industries are also exempt from IVA.

- Arbitration is mandatory for investments over $\$ 10$ million. Arbitration rules follow either UNCITRAL, ICC, and/or the Inter-American Commercial Arbitration Commission (CIAC).

COMEX is a key inter-ministerial council responsible for policy direction and interinstitutional coordination in foreign trade. Its responsibilities include approving and regulating trade policy in Ecuador. The issues it oversees range from defining Ecuador's foreign trade strategy and authorizing trade negotiations through to defining rules of origin, determining tariff increases, and designing trade measures. COMEX is chaired by a representative of the Ministry of Production, Foreign Trade, Investment and Fisheries and is composed inter alia of representatives of the following bodies: the Ministry of Agriculture and Livestock; the Ministry of Aquaculture and Fisheries; the Ministry of Industry and Productivity; the Ministry of Economy and Finance; the National Revenue Administration; and the National Secretariat of Planning and Development (SENPLADES). The National Customs Service of Ecuador also participates in COMEX although it does not have the right to vote. The permanent secretariat sits under the Vice-Ministry of Foreign Trade.

CEPAI is an inter-ministerial body with responsibility for defining policies and programs to foster, promote, and attract investment. It also grants approval for investment contracts and provides investors with assistance in implementing investment projects. Additionally, it is tasked with approving the National Strategic Plan to Promote Investments and with developing the fiscal incentives framework for investment in Ecuador. CEPAI was given the functions of the highest government body for investment matters in Ecuador. It is chaired by the Minister of Production, Foreign Trade, Investment and Fisheries, unless the president joins the meeting; and composed by the Ministry of Foreign Affairs, Ministry of Economy and Finance, and the National Secretariat of Planning and Development. The secretariat relies on the Vice-Ministry of Export and Investment Promotion.

COMEX and CEPAI appear to function well as fora for recurrent, inter-ministerial coordination at the highest level. Yet, due to the breadth and scope of their respective responsibilities, the two bodies tend to concentrate their work on tactical definitions and oversight, rather than on policy direction, vision, strategy, and prioritization.

\section{b. Best Practices on Institutional Arrangements}

Efficient institutional arrangements are highly idiosyncratic and must respond to the specific political economy of a country. However, most institutional frameworks demonstrate a common set of organizational and structural practices, according to comparative research. 
In many countries, four organizations comprise the institutional cluster in charge of leveraging FDI and international trade in order to foster job generation, technological upgrading, and development. To be effective, all four must have their own specific roles and responsibilities, yet at the same time be closely aligned and coordinated. They comprise:

\section{i. Ministerial Council}

A ministerial council typically oversees policy direction, prioritization, and coordination for trade and FDI. Its policies must be framed within the broader development strategy of a country. In addition, it is necessary for an array of public agencies to feed into the development of a national agenda for key areas such as physical infrastructure, transport (including logistics), digital infrastructure, human capital, access to finance, investment climate, science and technology. The missions and tasks of these agencies must be properly orchestrated. This function of orchestration is typically fulfilled by a ministerial-level council, often referred to as a 'Council for Competitiveness' or a 'Council for Productivity and Innovation'. Such a council is generally chaired by the leader of the government, with the close support of the lead ministry in charge of FDI and international trade policy. When not chaired by the president or prime minister, it requires a strong chairperson who holds political clout and has the capacity to resolve divergent policies and conflicting views.

Ministerial councils are, ideally, where economic policies geared towards fostering greater competitiveness and productivity take shape and where consensus as to how best to secure the benefits of trade and FDI is forged. They also provide the highest political instance where inter-agency coordination oversight can be ensured. Ministerial councils should involve ministers and the highest-ranking officials from areas such as: domestic trade and industrial policy, planning, agriculture, other productive sector ministries, education and skills development, science and technology, foreign affairs, and foreign trade and investment. An executive secretariat should manage the agenda, monitor progress, and ensure implementation of agreements.

Among the functions to be carried out by a Ministerial Council are:

- Coordination and articulation between government agencies - and eventually with the private sector as well - to improve policy implementation.

- Generation of consensus on objectives: aligning policy actions and setting sectoral priorities.

\section{ii. Lead Ministry for Foreign Trade and Investment Policy}

The lead ministry for foreign trade and investment policy undertakes the executive leadership role, including policy formulation, execution, and coordination. This marks an instance of a government's executive branch exerting political leadership based on its technical capacity as well as its understanding not only of the complex international trade and investment 
dynamics, but also of the interplay between trade, investment, and the domestic economy. The three tasks that a lead ministry should pursue are developed in Box $5 .{ }^{16}$

\section{Box 5. Key Function of a Lead Ministry for Trade and Investment}

(i) Formulation, analysis, and implementation of investment policies

- Design, formulate, and implement investment and trade policies in alignment with the country's development strategy.

- $\quad$ Collect, analyze, utilize, and disseminate investment and trade-related information, such as: statistical data on the domestic and international economy; regulatory barriers affecting investment, treaties, and other legal instruments; national laws and regulations; and external academic analyses and inhouse research to support eventual negotiations or deregulation policies.

- $\quad$ Provide independent assessment of negotiated investment agreements to ensure public scrutiny and legitimacy.

\section{(ii) Communication and Coordination}

- $\quad$ Ensure the flow of communication between the lead ministry and other government agencies, the private sector, and civil society organizations so that the formulation of investment policy plus the conduct of international trade and investment negotiations are inclusive and widely participative.

- $\quad$ Provide means of inter-agency coordination at the highest possible level.

- $\quad$ Consult with stakeholders so as to strengthen policy formulation and negotiation, as well as to build legitimacy.

\section{(iii) Representation}

a. Represent the country externally to foreign counterparts and international organizations, including a permanent presence in foreign missions as well as participation in trade and investment negotiations at the bilateral, regional, and/or multilateral level.

b. Ensure representatives are fully trained in trade and investment policy, as well as in negotiation techniques.

c. Encourage leading trade and investment representatives to be active, informed, and involved both at home and abroad, particularly with regards to shifting bilateral, regional, and multilateral negotiations.

Another key function of the lead ministry is to ensure the appropriate involvement of the private sector and other stakeholders in the making and execution of trade policy. This is very important during the negotiation of international agreements. Such cross-sectoral involvement should be done through appropriate information and consultation mechanisms. These include general information platforms (e.g. websites, media, public events), regular consultations on systemic issues (e.g. advisory councils at a political level comprising high-profile representatives), and regular and/or ad hoc consultations on sector-based issues (e.g. consultation tables with technical representatives from sectors).

\footnotetext{
${ }^{16}$ Example of countries with a lead Ministry for Foreign Trade and Investment are the United States (e.g. United States Trade Representative), the European Union (DG Trade); Japan (Ministry of International Trade and Industry), and Costa Rica (Ministry of Foreign Trade).
} 


\section{iii. $\quad$ An Export Promotion Agency}

For an economy to insert itself successfully into global markets, it is paramount that its domestic private sector can gradually connect with the international economy. Governments can facilitate this by helping domestic firms become direct exporters. They can also support firms to diversify their products and services or assist them in becoming first, second, or third-tier suppliers to FDI firms established in the host country. This type of support for the domestic private sector is often carried out by Export Promotion Agencies (EPA), whose mission is to prepare domestic companies to export as part of an integrated internationalization process.

EPAs are specialist agencies that promote foreign trade by providing programs that assist domestic producers of goods and services to access international markets. In close coordination with other ministries whose mandate is to assist national producers, the EPA acts as an executing arm of the lead ministry that supports the internationalization of domestic firms. ${ }^{17}$ The services offered by EPAs can be divided into four broad categories:

- Country image building: advertising and promotional events.

- Export support services: exporter training, technical assistance, and capacity building (including in regulatory compliance), plus the provision of information on trade finance, logistics, customs, packaging, and pricing.

- Marketing: trade fairs, exporter and importer missions, and follow-up services offered by representatives abroad.

- Market intelligence and publications: general information on different export markets and sectors, as well as firm-level data, such as market surveys, specialized publications, and contact details for importers and exporters.

While export and FDI promotion are often merged in a single agency, it is important to clearly differentiate their respective functions. Export promotion and investment promotion are, by nature, substantively different. It is vital that the responsible agency recognizes this if it is to secure optimum outcomes in both its respective functions. The expertise and skills required for each function in substantially different, for instance. So too are the respective audiences for each function. Table 9 presents the key differences between the two functions, while Table 10 discusses the pros and cons of joint promotion agencies.

Table 9: Contrasting Export Promotion Agencies with Investment Promotion Agencies

$$
\begin{array}{|l|l|}
\hline \text { Export Promotion } & \text { Investment Promotion }
\end{array}
$$

\footnotetext{
${ }^{17}$ In accordance with a country's particular national economic development plans, the specific objectives of EPAs will vary. For example, in some regions, EPAs will be mandated to promote overall exports, whereas in other cases the promotion of non-traditional exports will be its primary focus. Other EPAs, meanwhile, may concentrate instead on particular sectors and not have such a broad objective.
} 


\begin{tabular}{|c|c|c|}
\hline Central mandate & $\begin{array}{l}\text { Support national producers to } \\
\text { sell goods and services in } \\
\text { international markets. }\end{array}$ & $\begin{array}{l}\text { Target foreign investors to attract, retain, and } \\
\text { expand FDI into host country. }\end{array}$ \\
\hline Staff skillset & $\begin{array}{l}\text { Sales and marketing officers } \\
\text { with sector-level knowledge } \\
\text { demands in external markets. }\end{array}$ & $\begin{array}{l}\text { Political economy, public relations, marketing, } \\
\text { and sector-level knowledge of business } \\
\text { realities in the host country. }\end{array}$ \\
\hline $\begin{array}{l}\text { Constituencies/client } \\
\text { targets }\end{array}$ & $\begin{array}{l}\text { Domestic producers/domestic } \\
\text { exporters. Often SMEs. }\end{array}$ & $\begin{array}{l}\text { Foreign investors/multinational companies and } \\
\text { HQ's locations. }\end{array}$ \\
\hline Support & Full support of local industry. & $\begin{array}{l}\text { Partial support of local industry; inherent fear } \\
\text { of foreign competition. }\end{array}$ \\
\hline $\begin{array}{l}\text { Performance } \\
\text { indicators }\end{array}$ & $\begin{array}{l}\text { Export volume; number of new } \\
\text { markets; number of new } \\
\text { exporters. }\end{array}$ & $\begin{array}{l}\text { FDI inflows; number of investment projects; } \\
\text { number of jobs created. }\end{array}$ \\
\hline
\end{tabular}

Source: Authors' own elaboration.

Table 10: Pros and Cons of Joint Export and Investment Promotion Agencies

\begin{tabular}{|ll|}
\hline \multicolumn{1}{|c|}{ Advantages } & \multicolumn{1}{c|}{ Disadvantages } \\
$\begin{array}{l}\text { One umbrella for investment and } \\
\text { trade promotion policy }\end{array}$ & $\begin{array}{l}\text { Different functions and objectives. } \\
\text { Loss of accountability and loss of } \\
\text { focus in the agency }\end{array}$ \\
\hline $\begin{array}{l}\text { Shared support services: IT, human } \\
\text { resources, accounting, legal services, } \\
\text { public relations, research and } \\
\text { analysis, shared office } \\
\text { accommodation }\end{array}$ & $\begin{array}{l}\text { Possible problems in coordinating } \\
\text { investment and trade promotion } \\
\text { activities and managing staff with } \\
\text { different skills and perspectives }\end{array}$ \\
\hline $\begin{array}{l}\text { Knowledge-sharing, to benefit } \\
\text { strategy development }\end{array}$ & $\begin{array}{l}\text { Different time frames, with generally } \\
\text { a longer time perspective in } \\
\text { investment promotion }\end{array}$ \\
\hline $\begin{array}{l}\text { Potentially more continuity in service } \\
\text { delivery. A single point of contact in } \\
\text { government, e.g., for export-oriented } \\
\text { investors }\end{array}$ & $\begin{array}{l}\text { Often different clients and contact } \\
\text { points in companies }\end{array}$ \\
\hline
\end{tabular}

Source: IPA’s Benchmarking Study, World Bank Group, 2017

\section{iv. An Investment Promotion Agency}

An effective and efficient Investment Promotion Agency (IPA) is a proactive provider of services targeted to foreign investors. An IPA's main mandate is to attract FDI and provide specialized support services to foreign investors with the aim of them establishing a presence in the host country and expanding their business there. Best-in-class IPAs are investor-centric organizations focused on providing services throughout an overseas firm's investment life cycle (Figure 25). 
Figure 25: The Foreign Direct Investment Lifecycle

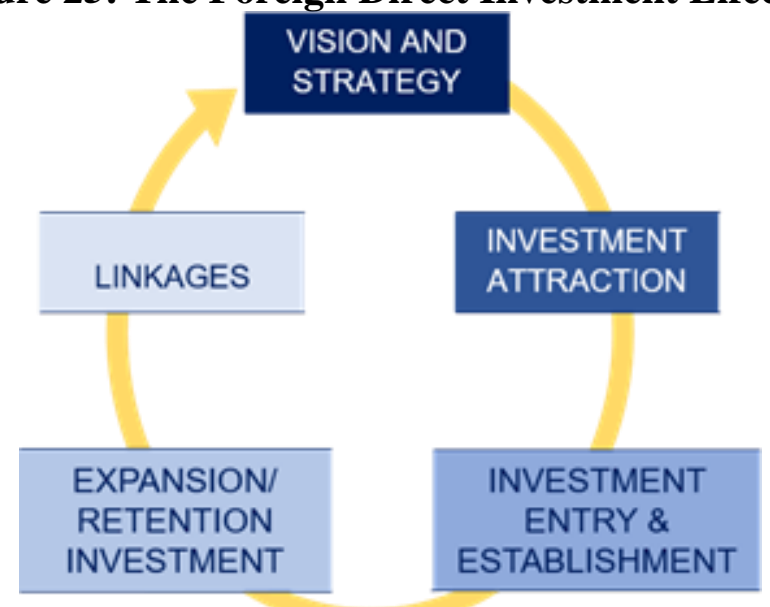

Source: The World Bank Group (2017)

The key functions of an IPA during the investment life cycle are to:

- Create awareness, build the country's image, and generate positive interest about a country as an attractive investment destination.

- Target foreign investors through a proactive, sector-specific outreach program and influence them to establish their investment in the host economy.

- Support the establishment of investment projects and facilitate the setting-up process in the country.

- Provide support and assistance to investors after the setting-up phase; help to promote reinvestment and expansion; assist in ensuring that grievances, conflicts, and investment withdrawal are dealt with and/or avoided.

- Advocate before governmental authorities and other stakeholders to influence changes in the host economy's investment climate, in light of feedback from foreign investors.

For countries that have successfully attracted FDI for domestic transformation, IPAs take the form of specialized agencies that act as an executing arm of the lead ministry. In this function, they help operationalize the country's investment promotion strategy through focused promotional activities. These activities seek to attract FDI in targeted sectors and to facilitate the establishment and expansion of investors in the host country. Such a mission requires dedicated budgets and specialized human resources.

Good practice suggests that it is helpful for governments to separate regulatory and FDI promotional roles. The FDI process involves a wide range of regulatory processes. Examples include: administering and issuing licenses, incentives and permits; managing state lands or assets; and administering or negotiating government concessions and/or public private partnerships. Research has shown that assigning such regulatory functions to an IPA is likely to distract it from 
the already complex and demanding role of attracting, facilitating, and expanding FDI in the host country. Successful cases such as Ireland and Costa Rica have ensured that their IPAs focus exclusively on FDI attraction, retention, and expansion (mainly efficiency-seeking FDI). Furthermore, a key lesson derived from past successes is the extreme importance of IPAs having financial and operational autonomy as this enables them to emulate private-sector flexibility and to execute their FDI promotion strategy with a business-centric focus. This is the institutional framework for Chile, Costa Rica, and Ireland, as presented in Annex 6.2.

Services provided by IPAs are generally classified into four key categories:

- Marketing services: image building initiatives and targeted promotion.

- Information services: specialized information on the location necessary for attracting investment during entry and establishment phases, as well as for expansion.

- Assistance services: facilitation services in the entry, establishment, or expansion stage of the investment, including the resolution of claims and grievances.

- Advocacy services: influencing and advocating policy reforms for a better business environment.

\section{c. Policy Recommendations}

Ecuador's foreign trade and investment agencies have recently undergone significant institutional restructuring, as described above. This context provides an opportunity to consider how best to carry out trade and investment policy making and promotion, as well as inter-institutional coordination as it relates to trade and investment.

The primary recommendations for improving Ecuador's institutional framework that emerge from this review are as follows:

1. Collaboration and coordination between the vice-ministries of the umbrella ministry should be promoted in order to enhance synergies, avoid duplicity of functions, and enhance service provision. The consolidation and transformation of different agencies into one single organization might generate efficiencies and rationalization but it does not necessarily create convergence. Proactive coordination efforts between the vice-ministries can generate synergies and facilitate integrated projects and initiatives. These collaborative initiatives can eliminate silos among business units. They can also be an effective way of creating alignment, achieving convergence, and ultimately providing better services to exporters and importers.

2. The Ministry of Production, Foreign Trade, Investment and Fisheries should be responsible for the negotiation and subscription of international investment agreements. This ministry has been awarded a comprehensive mandate to lead on foreign trade and investment policy issues. As such, it should be the chief entity responsible for defining 
Ecuador's policies regarding international investment agreements and for taking a lead in negotiations related to these agreements. This is not presently the case, however. Under the terms of Decree No 252, it is the Ministry of Foreign Affairs that is tasked with leading investment agreement negotiations. Thought should be given to switching this function to the Ministry of Production, Foreign Trade, Investment, in line with its status as the lead ministry for investment in Ecuador. This does not imply that the Ministry of Foreign Affairs will become sidelined. Together with other government entities, it could play an active role in trade and investment issues through collaborative fora such as CEPAI and COMEX.

3. CEPAI should focus on defining Ecuador's investment vision and strategy, as well as the direction of its strategic policy on investment matters. It should avoid getting absorbed in more operational issues. It is set up as a high-level forum for policy formulation and should conform to that goal. Reinforcing CEPAI with a permanent technical body is advisable and merits attention. This body could analyze and define recurring topics, such as the awarding of investment contracts, the monitoring of compliance, and the overall administration of these contracts.

4. COMEX should concentrate on the overall direction and coordination of Ecuador's foreign trade policies. COMEX should continue to be a high-level forum mandated to drive and guide the country's foreign trade policies. It should avoid getting absorbed in the resolution of individual cases and more operational issues. Reinforcing COMEX with technical bodies that can address and define such matters deserves close consideration.

5. It may be necessary to reassess the decision to include export and investment promotion within the Vice-Ministry of Promotion as this dual responsibility may be reducing the organization's effectiveness. With the creation of the Vice-Ministry of Promotion and corresponding Sub-Secretariats, the breadth and scope of the export promotion and investment promotion functions have been hampered and weakened. Global best practice reveals that promotion agencies usually are technical and specialized executing entities, with considerable autonomy and budgetary independence from lead ministries. In Ecuador's case, the decision to subsume promotion functions within a single umbrella ministry seems to have reduced the institutional rigor with which these functions are now carried out.

6. Ecuador's investment promotion functions need to be revamped. Over the years, ProEcuador's mandate as an investment promotion agency seems to have been deprioritized vis-à-vis its export promotion functions. To fill this gap, impromptu and temporary initiatives such as InvestEcuador have arisen. Moreover, within the recently created Sub-Secretariat for Investment promotion, the focus seems to be on investment policy making and regulation, rather than on investment promotion. Any organizational structure should avoid predominance or displacement of some functions over others, as currently appears to be the case. It is also 
important to recognize that investment promotion functions are strategically significant when it comes to boosting a country's FDI inflows. These functions are distinctive from export promotion functions. A separate, proactive investment promotion strategy is therefore required. This should target a handful of key sectors. A clear mandate focused on providing professional support services to investors throughout the investment life cycle should also be considered. Such a life cycle approach would assist not only with attracting investors. Thanks to the provision of ongoing operational assistance, it would also serve to deepen relationships with foreign investors. Couple this dispute prevention and grievance resolution services, meanwhile, and rates of investment retention and expansion are also likely to increase.

\subsection{Trade Policy and Protection}

Ecuador's trade policy during the last decade has been characterized by passivity on the international stage and protectionism at the local level. At the same time, peer nations have been strengthening relations with one another and with higher-income nations. Consequently, Ecuador's level of connection with international markets falls well below that of other countries in the region. This section examines how Ecuador's trade policy over the last decade has impacted its economic competitiveness.

\section{a. Impact of the Pacific Alliance Agreement on the Competitiveness of Ecuadorian Firms}

Set up in 2011 by Chile, Colombia, Mexico, and Peru, the Pacific Alliance is a trade bloc that provides its four member states with freedom of movement for goods, services, capital, and people. As stated in its founding document, the Lima Declaration, the goal of the alliance is to capitalize on growing economic opportunities in Asia by integrating members' domestic markets. The initiative has resulted in the Alliance's members integrating their stock exchanges, reducing tariffs, and removing visa requirements for travel, among other joint actions. In the past, Ecuador has been critical of the Pacific Alliance, mostly for differences in political and ideological views, despite the fact that its economy is relatively integrated with Colombia and Peru (by virtue of the Andean Community trade agreement) and with Chile (by virtue of a bilateral trade agreement).

The Pacific Alliance represents an important destination for Ecuadorian exports and an important origin for Ecuadorian imports. In 2011, the Alliance's four signatory nations accounted for almost 20 percent of Ecuador's non-oil exports and over 25 percent of its non-oil imports. Almost half of Ecuadorian exports to the Pacific Alliance were concentrated in primary products such as minerals and agriculture. Imports from the Pacific Alliance were more diversified, with less than 20 percent concentrated in primary products.

The Pacific Alliance increased the relative cost of doing business in Ecuador for firms in its member countries; this probably had a negative impact on Ecuadorian exporters and importers. Additionally, the concentration of primary products in the export basket creates the 
possibility that Pacific Alliance countries source these products from other member states rather than from Ecuador. In fact, before 2011, Ecuadorian exports to Pacific Alliance countries followed a similar trend as exports to countries outside the trade bloc. Since 2011, however, exports to the Pacific Alliance have diverged from exports to the rest of the world. In the first five years after the agreement was signed, the former decreased by 20 percent overall, while the latter increased by 20 percent (Figure 26). Imports followed a similar trend, although the divergence between imports from the Pacific Alliance and from the rest of the world is smaller (Figure 27).

\section{Figure 26: Ecuadorian Exports to the PA}

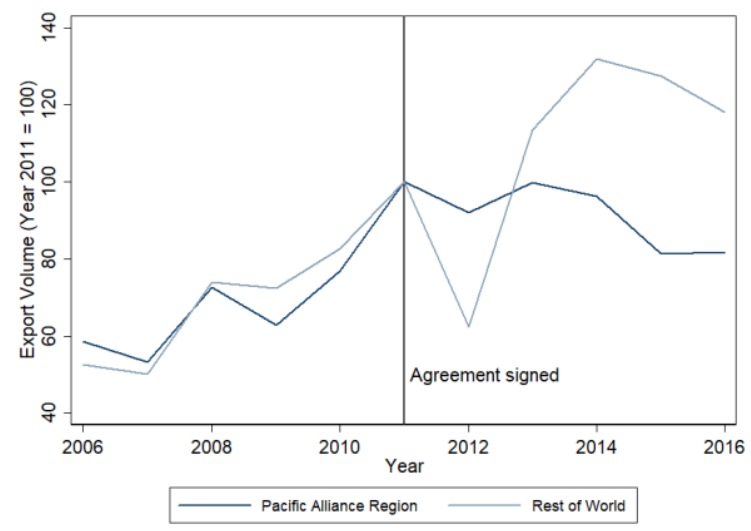

Note: This figure shows Ecuadorian export volume by year. The dark blue line indicates exports to Chile, Colombia, Mexico, and Peru. The light blue line indicates exports to all other countries. Exports are indexed to 2011 values for each group of countries.

Source: Authors' calculation using COMTRADE data.
Figure 27: Ecuadorian Imports from the PA

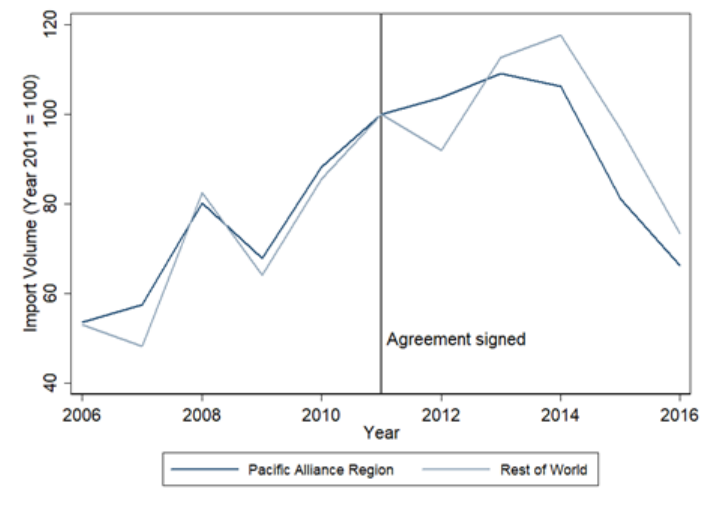

Note: This figure shows Ecuadorian import volume by year. The dark blue line indicates imports from Chile, Colombia, Mexico, and Peru. The light blue line indicates imports from all other countries. Imports are indexed to 2011 values for each group of countries. Source: Authors' calculation using COMTRADE data.

A formal estimation of the Pacific Alliance's impact on the competitiveness of Ecuadorian traders shows that Ecuador's decision not to join decreased overall exports by 16 percent for exposed firms relative to non-exposed firms - equivalent to around $\$ 600$ million per year. Details of this calculation are detailed in Box 6.

\section{Box 6. Estimating the effect of the Pacific Alliance on Ecuadorian firms}

To estimate the effect of the Pacific Alliance on Ecuadorian exporters and importers, we follow a Difference-In-Differences (DID) strategy. The implementation of the trade agreement in 2011 acts as a "treatment," impacting some firms more than others. The DID strategy involves comparing the exports (imports) of treated firms versus control firms (first difference) and after versus before policy (second difference). To identify treated firms, we calculate the share of each firm's exports (imports) to Pacific Alliance countries before 2011. The average share is 0.25 for exports and 0.24 for imports. We consider a firm treated if its share of exports (imports) to Pacific Alliance countries was above average. We then estimate regressions in which the dependent variable is the logarithm of exports (imports) for each firm in each year from 2002-2017. The independent variables are a firm fixed effect (to control for overall differences across firms), an indicator for all firms in post-2010 years (to control for overall time trends), 
and an indicator for treated firms in post-2010 years (to identify the treatment effect). Note that because of the firm fixed effect, it is unnecessary to include an indicator for treated firms in all years.

Table B6.1 displays the results for exporters. Column 1 includes all exporters. In Column 2, we restrict the sample to pure exporters: i.e. firms that export but do not import. In Column 3, we restrict the sample to importer-exporters: i.e. firms that both import and export. Because the dependent variable is logarithmic and the independent variable is binary, the coefficients have the interpretation of a percentage difference. Thus, Column 1 suggests that the Pacific Alliance reduced exports of treated firms by around 16 percent. This effect is highly statistically significant. For pure exporters, the effect is positive but not significant. For importer-exporters - i.e. the firms most exposed to international markets - the effect is both more negative and more significant than the overall effect. Table B6.2 displays analogous results for importers, where a very different picture emerges. In all columns, we see that the Pacific Alliance had a small and statistically insignificant effect on overall imports.

Table B6.1: Treatment Effect of Pacific Alliance on Ecuadorian Exports

\begin{tabular}{lccc}
\hline & $\begin{array}{c}\text { Log Export Value } \\
(1)\end{array}$ & $\begin{array}{c}\text { Log Export Value } \\
(2)\end{array}$ & $\begin{array}{c}\text { Log Export Value } \\
(3)\end{array}$ \\
\hline & & & \\
Treated*Post-2010 & $-0.160^{* * *}$ & 0.189 & $-0.252^{* * *}$ \\
& $(0.0573)$ & $(0.118)$ & $(0.0750)$ \\
Post-2010 & $0.652^{* * *}$ & $0.645^{* * *}$ & $0.584^{* * *}$ \\
& $(0.0310)$ & $(0.0379)$ & $(0.0562)$ \\
& & & \\
Sample & All Exporters & Pure Exporters & Importer-Exporters \\
Firms & 5946 & 3520 & 2812 \\
Observations & 35782 & 17883 & 16823 \\
R-squared & 0.838 & 0.847 & 0.842 \\
\hline
\end{tabular}

Table B6.2: Treatment Effect of Pacific Alliance on Ecuadorian Imports

\begin{tabular}{lccc}
\hline & $\begin{array}{c}\text { Log Import Value } \\
(1)\end{array}$ & $\begin{array}{c}\text { Log Import Value } \\
(2)\end{array}$ & $\begin{array}{c}\text { Log Import Value } \\
(3)\end{array}$ \\
\hline \multirow{2}{*}{ Treated*Post-2010 } & 0.0172 & 0.00640 & 0.0705 \\
& $(0.0225)$ & $(0.0241)$ & $(0.0552)$ \\
Post-2010 & $0.420^{* * *}$ & $0.403^{* * *}$ & $0.528^{* * *}$ \\
& $(0.0115)$ & $(0.0120)$ & $(0.0458)$ \\
Sample & & & \\
Firms & All Importers & Pure Importers & Importer-Exporters \\
Observations & 27556 & 26364 & 2812 \\
R-squared & 171517 & 152632 & 16823 \\
& & & 0.885 \\
\hline
\end{tabular}

Five patterns emerge from the analysis:

i. The Pacific Alliance had a large, negative effect on the overall exports of Ecuadorian firms, but no effect on their overall imports. The results indicate that 
the Pacific Alliance reduced overall exports of Ecuadorian firms by 16 percent on average. In contrast, no impact is found on overall imports of Ecuadorian firms (Box 6 and Figure 28).

ii. The agreement had a large and negative effect on the exports and imports of Ecuadorian firms specifically to Pacific Alliance countries. Focusing on transactions with Chile, Colombia, Mexico, and Peru - the countries that joined the Pacific Alliance - the results indicate that the agreement had a large, negative effect on both exports and imports. On average, exports and imports were both over 100 percent lower for firms that were highly exposed to Pacific Alliance countries before the agreement was signed, relative to firms that were not highly exposed (Figure 28 and Figure 29).

Figure 28: Impact of the PA on Exports

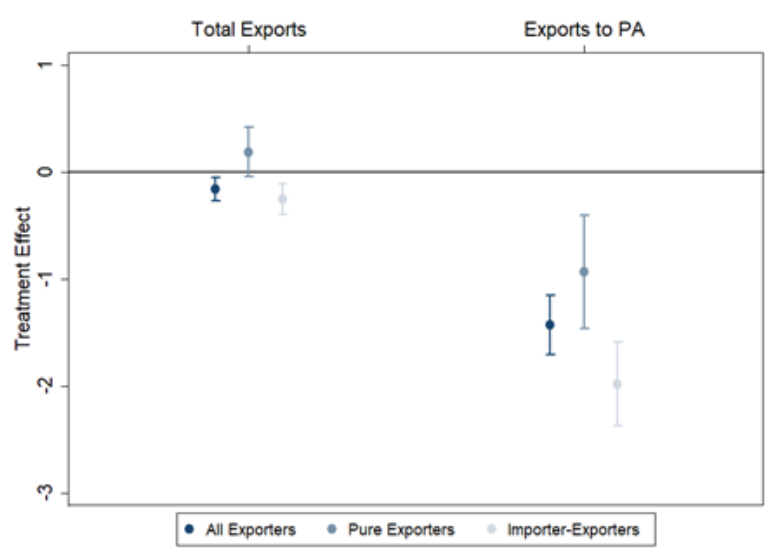

Note: This figure shows the treatment effect of the Pacific Alliance on Ecuadorian exports. Each point represents the treatment effect from a different regression. For numerical estimates, see Annex 6.3. Source: Authors' estimation using data from Ecuador's Central Bank.
Figure 29: Impact of the PA on Imports

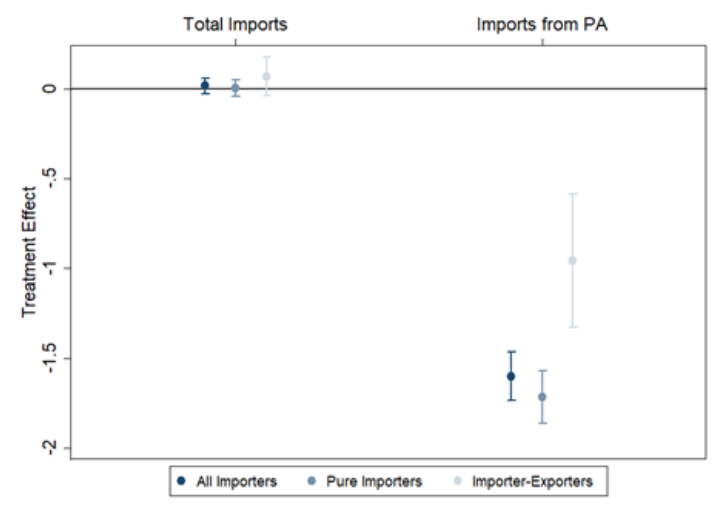

Note: This figure shows the treatment effect of the Pacific Alliance on Ecuadorian imports. Each point represents the treatment effect from a different regression. For numerical estimates, see Annex 6.3. Source: Authors' calculation using data from Ecuador's Central Bank.

iii. The negative effect on exports was stronger for firms that were more engaged in international markets. Estimating the impact separately for pure exporters and for importer-exporters shows that the negative effect of the Pacific Alliance was much stronger for importer-exporters. Exports in general were 25 percent lower for these firms after the agreement was signed (Figure 28), while exports to Pacific Alliance countries in particular were almost 200 percent lower (Figure 29). In contrast, the effect was weaker for pure exporters.

iv. The reduction in exports to the Pacific Alliance was reflected in fewer exports of existing exporters (the intensive margin) rather than fewer firms exporting to the 
region (the extensive margin). The overall negative impact of the Pacific Alliance reflects the export performance of continuing exporters, as well as the entry and exit of firms into the exporting activity. To disentangle these two effects, we estimate the probability of firms continuing to export after the agreement was signed. Fewer than 70 percent of exporters continue to be active after the agreement was signed, but there is no difference between treated and control firms (Figure 30). This suggests that the effect of the Pacific Alliance was concentrated mostly on the intensive margins: i.e. treated firms continued to export but reduced the volume of their exports.

v. The negative impact of the Pacific Alliance on Ecuadorian Exports developed gradually, growing more negative over time. Although a trade agreement can be implemented quickly, it may take several years for its effects to be felt. To investigate this possibility, we estimate the effect of the Pacific Alliance in each of the years following 2011, when it was signed. We see that the effect is felt immediately, but then grows stronger over time (Figure 31). Exports are just 5 percent lower in 2011. By 2017, however, they are nearly 40 percent lower for treated firms. This coincides with the full integration of the stock exchange in 2014 and the removal of 92 percent of tariffs within the Pacific Alliance in 2016.

Figure 30: Probability of Survival in Export and Import Markets

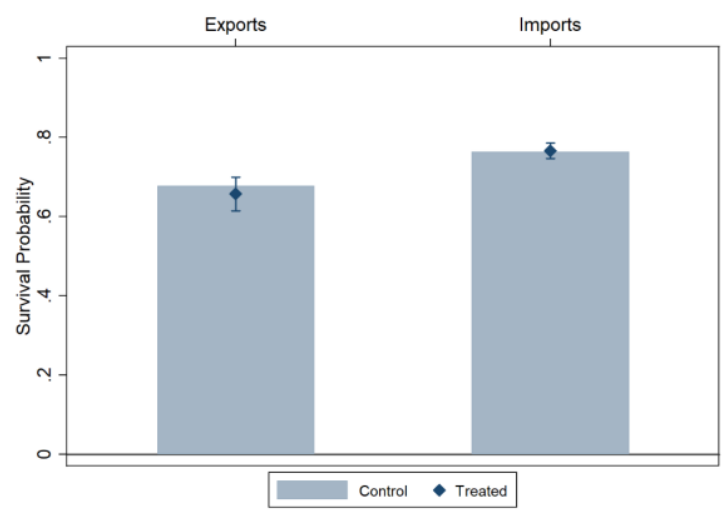

Note: This figure shows the treatment effect of the Pacific Alliance on the probability of survival in export and import markets. We identify all firms that were active in export or import markets for at least three years between 2002-2010. The dependent variable is an indicator for whether the firm remained active for at least three years between 2011-2017. The independent variables are a constant and an indicator for treated firms. The bar represents control firms, and the dot represents treated firms. For numerical estimates, see Annex 6.3.Source: Authors' estimation using data from the Central Bank.
Figure 31: Impact of the PA on Exports over Time

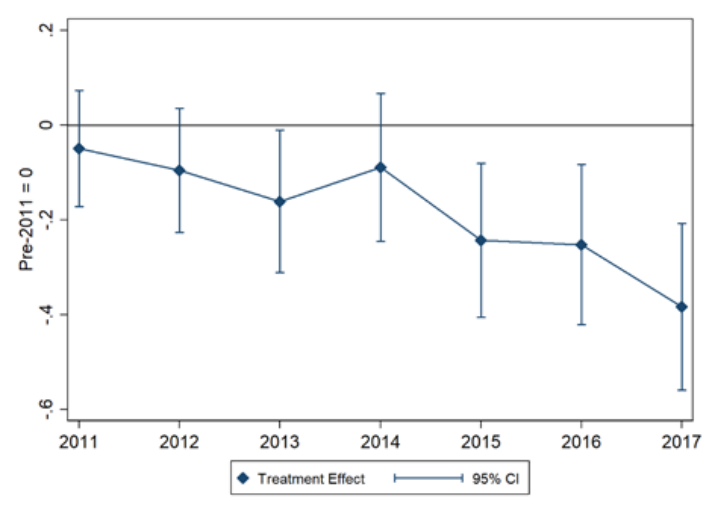

Note: This figure shows how the treatment effect on Ecuadorian exports evolves over time. Each point represents the treatment effect for a different year. The dependent variable is log total exports, and the sample is all exporters. The independent variables are a firm fixed-effect, an indicator for each year from 2011-2017, and an indicator for treated firms for each year from 2011-2017. For numerical estimates, see Annex 6.3.

Source: Authors' estimation using data from the Central Bank. 


\section{b. Effects of Ecuador's Trade Protection on Productivity and Value Added.}

Negative consequences for productivity growth can result from tariff schedules that place high import duties on final goods (to protect them from import competition) and low tariffs on inputs (to promote their local transformation). This policy, known as tariff escalation, can backfire in environments where output markets have limited competition from external and/or internal forces. This is due to the increased markups and lower innovation that can result. ${ }^{18}$ While the objective of the policy is to support domestic producers, such producers could end up facing tariffs on imported inputs that cause production costs to rise. To understand the effects of tariffs on a specific sector, it is therefore necessary to analyze the total effect of the entire tariff structure on its value chain - the effective rate of protection. Tariff escalation could lead to high effective rates of protection. In an environment with limited domestic competition, such a trade policy could incentivize inputs to flow from more productive industries to less productive industries. This would result in a lower level of aggregate productivity. However, international evidence suggests that growth is driven mainly by productivity-enhancing reallocation. Measuring the impact of the structure of Ecuador's trade policy on various outcomes is therefore key to assessing future drivers of growth.

\section{An evaluation of Ecuador's tariff schedule reveals a substantial level of protection in output markets, especially in the apparel sector. While the average Most-Favored Nation (MFN) tariff rate remained relatively stable for all sectors in 2008-2017, Ecuador applies compound tariffs to around 5 percent of tariff lines. ${ }^{19}$ These compound tariffs are mostly focused on the apparel and clothing sector. Once compound tariffs are transformed to ad valorem equivalents, the value of protection doubles for the sector. ${ }^{20}$ Table 11 shows the products with high level of protection.}

\section{Table 11: Tariffs lines with Compound Tariffs}

\footnotetext{
18 Tariff escalation can also have negative welfare effects because higher prices derived from a non-competitive environment result in lowering consumption and the pricing out of some consumers from the market (Aghion et al. 2005). Incentives for import-substituting industries and distortions in input markets could also result in a misallocation of resources in the economy, detrimentally affecting aggregate productivity (Eslava et al. 2004).

${ }^{19}$ The MFN tariff is the lowest rate that the country applies to its trading partners. According to the WTO principle of non-discrimination, this tariff rate must be applied to all WTO member nations. Compound tariffs are special tariffs that include both an ad valorem component and a specific component defined per imported volume or units.

20 The ad valorem equivalent was computed using Ecuador's import value and quantity at the ten digit-level for lines where the compound duties are defined per weight or units (compound tariffs expressed in degrees of alcohol content could not be computed).
} 


\begin{tabular}{|cll|}
\hline $\begin{array}{c}\text { HS } \\
\text { chapter }\end{array}$ & \multicolumn{1}{c|}{ Description } & $\begin{array}{c}\text { Number of tariff lines } \\
\text { with compound tariffs }\end{array}$ \\
22 & Beverages, spirits and vinegar & 20 \\
40 & Rubber and articles thereof & 8 \\
61 & $\begin{array}{l}\text { Articles of apparel and clothing } \\
\text { accessories, knitted or crocheted }\end{array}$ & 133 \\
\hline 62 & $\begin{array}{l}\text { Articles of apparel and clothing } \\
\text { accessories, not knitted or crocheted }\end{array}$ & 122 \\
63 & Other made-up textile articles & 67 \\
64 & Footwear, gaiters and the like & 28 \\
\hline 69 & Ceramic products & 5 \\
76 & Aluminium and articles thereof & 6 \\
\hline 85 & Electrical machinery and equipment and & 28 \\
96 & parts thereof & 1 \\
\hline
\end{tabular}

Note: Compound tariff is the nominal protection based on MFN and other import duties, including antidumping, tariff surcharges, and non-ad-valorem compound tariffs

Source: World Trade Organization 2019

Between March 2015 and May 2017, Ecuador operated a balance-of-payments safeguard policy that affected 38 percent of tariff headings (representing 31 percent of imports recorded in 2014) and thus raised the level of protection. This surcharge was applied at ad valorem rates of 5 percent, 15 percent, 25 percent, and 45 percent (Table 11). Almost half of the products affected faced the highest surcharge. These additional charges raised the nominal protection rate above 40 percent on average across all tariff lines in 2016. In January of that year, Ecuador proposed gradually removing tariff surcharges to WTO members in a six-phase process, starting in January 2016 and ending in June 2017. The removal schedule was implemented as planned.

The computation of effective rates of protection reflects Ecuador's 2007 tariff escalation regime, which was established with the goal of incentivizing domestic value addition, protecting jobs, and substituting imports of final products for domestic production. Reductions in the MFN nominal tariff rates were mostly focused on primary products, inputs, and capital goods, whereas increases concentrated on durable and non-durable consumer goods. Employing the 2012 input-output matrix, we compute effective rates of protection (including MFN rates with compound tariffs and other duties) for around 150 tradable sectors. ${ }^{21}$ The results indicate

\footnotetext{
${ }^{21}$ The effective rate of protection accounts for the protection of the output market net of the its inputs' protection. Specifically, the effective rate of protection is defined as $E R P=\frac{t-\sum a_{i} t_{i}}{1-\sum a_{i}}$. The effective protection rate does not depend only upon the nominal tariff (t) but also upon the proportion of imported input cost in the total cost of producing the commodity (ai) and the tariff rate imposed on the imported input (ti).
} 
that the effective rate of protection is on average larger than the nominal rate, indicating a policy to liberalize inputs and protect final products (tariff escalation). ${ }^{22}$

Table 12: Distribution of Tariff Surcharge across Sectors

\begin{tabular}{|c|c|c|c|c|c|c|c|c|}
\hline sector & $\begin{array}{c}\text { number of } \\
\text { tariff lines } \\
\text { with } \\
\text { surcharges }\end{array}$ & $\begin{array}{c}\text { number of } \\
\text { surcharges } \\
\text { actually } \\
\text { applied }\end{array}$ & $\begin{array}{c}\% \text { of } \\
\text { imported } \\
\text { products with } \\
\text { surcharge }\end{array}$ & $\begin{array}{c}\text { number of } \\
\text { prods with } \\
45 \% \\
\text { surcharge }\end{array}$ & $\begin{array}{c}\text { number of } \\
\text { prods with } \\
25 \% \\
\text { surcharge }\end{array}$ & $\begin{array}{c}\text { number of } \\
\text { prods with } \\
15 \% \\
\text { surcharge }\end{array}$ & $\begin{array}{c}\text { number of } \\
\text { prods with } \\
5 \% 6 \\
\text { surcharge }\end{array}$ & $\begin{array}{l}\text { Avg. } \\
\text { surcharge } \\
\text { affected } \\
\text { prods (\%6) }\end{array}$ \\
\hline Animal Prods & 117 & 39 & 40.6 & 33 & 0 & 1 & 5 & 39.1 \\
\hline Vegetable Prods & 149 & 85 & 48.0 & 69 & 0 & 13 & 3 & 39.0 \\
\hline Fats and Oils & 3 & 2 & 5.6 & 1 & 0 & 1 & 0 & 30.0 \\
\hline Foodstuffs & 248 & 169 & 79.7 & 124 & 19 & 11 & 15 & 37.2 \\
\hline Mineral Prods & 7 & 5 & 3.7 & 5 & 0 & 0 & 0 & 45.0 \\
\hline Chemicals & 34 & 28 & 2.8 & 22 & 0 & 4 & 2 & 37.9 \\
\hline Plastics & 78 & 73 & 25.3 & 45 & 2 & 5 & 21 & 30.9 \\
\hline Hides, Leather, Furs & 34 & 30 & 75.0 & 29 & 0 & 1 & 0 & 44.0 \\
\hline Wood & 33 & 18 & 32.7 & 18 & 0 & 0 & 0 & 45.0 \\
\hline Pulp and Paper & 43 & 40 & 25.2 & 36 & 0 & 3 & 1 & 41.8 \\
\hline Textiles & 825 & 673 & 93.1 & 19 & 287 & 6 & 361 & 14.7 \\
\hline Footwear/Headgear & 50 & 44 & 88.0 & 17 & 25 & 2 & 0 & 32.3 \\
\hline Stone/Glass & 65 & 59 & 38.6 & 54 & 2 & 3 & 0 & 42.8 \\
\hline Precious Metals & 52 & 26 & 100.0 & 11 & 0 & 1 & 14 & 22.3 \\
\hline Base Metals & 264 & 245 & 42.0 & 135 & 0 & 64 & 46 & 29.7 \\
\hline Machinery & 511 & 473 & 40.7 & 194 & 2 & 194 & 83 & 25.6 \\
\hline Transport & 112 & 76 & 44.7 & 62 & 1 & 12 & 1 & 39.5 \\
\hline Optical/Medical & 168 & 161 & 60.8 & 61 & 0 & 88 & 12 & 25.6 \\
\hline Arms & 10 & 5 & 83.3 & 5 & 0 & 0 & 0 & 45.0 \\
\hline Miscellaneous & 143 & 136 & 90.7 & 119 & 0 & 13 & 4 & 41.0 \\
\hline Art & 5 & 5 & 71.4 & 5 & 0 & 0 & 0 & 45.0 \\
\hline Special & 12 & 3 & 15.8 & 0 & 1 & 0 & 0 & 25.0 \\
\hline All Sectors & 2,963 & 2,395 & 43.4 & 1,064 & 339 & 422 & 568 & 27.4 \\
\hline
\end{tabular}

Note: The number of surcharges applied refers to the number of products that were imported with a tariff surcharge as of March 2015.

Source: Authors' calculation.

The ample array of compound tariffs (a combination of ad valorem tariffs and volume or quantity-specific duties) negatively affected Ecuador's value added and total factor productivity (TFP) growth. Employing an econometric model, we estimate the impact of the nominal and effective protection structure with and without compound tariffs and other duties on value added and total factor productivity growth for the period $2007-2017 .{ }^{23}$ Results indicate that compound tariffs and other duties had a significant, negative impact on sectoral productivity and

\footnotetext{
${ }^{22}$ For instance, agriculture, livestock, forestry, and fishing face a median effective protection rate that is substantially higher than the nominal rate. However, significant heterogeneity persists within industries. For example, basic manufacturing shows higher median and average nominal and effective rates compared to those from more sophisticated manufacturing sectors.

${ }^{23}$ We use a fixed-effect mode to relate changes in tariffs to industry-level productivity and value-added outcomes. Industry-level performance measures were computed using the financial statements for each formal firm included in the business registry database (Superintendencia de Compañias) between 2007 and 2017. Industry outcomes are aggregated at the industry level, weighting the firm by its importance in the sector.
} 
value added. In other words, the sectors that are protected by these cumbersome tariffs show relatively lower productivity and value added than other sectors. Figure 32 and Figure 33 depict the effects of import protection on TFP and value-added growth, respectively. Regression results appear in the appendix. ${ }^{24}$

Figure 32: The Effect of Import Protection on Sectoral TFP Growth

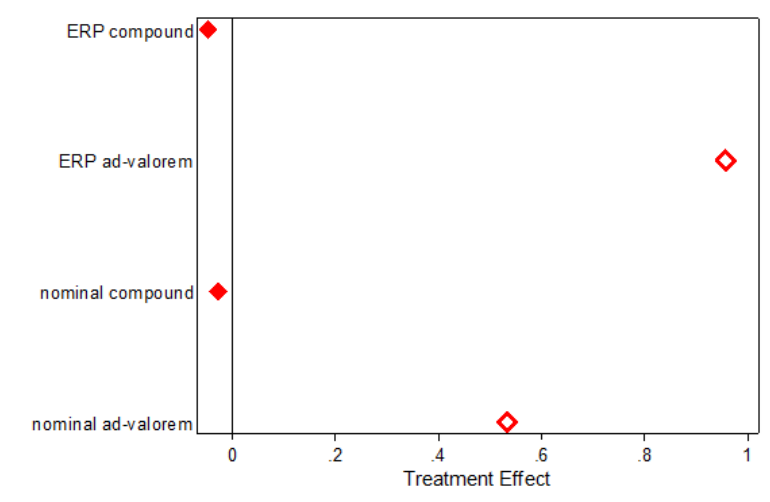

Note: The red diamond presents the estimated coefficients from fixed-effect regressions where the dependent variable is TFP growth and where the controls were the four different measures of import protection. Hollow diamonds represent coefficients that are not statistically significant at the 95 percent confidence interval. Results are shown in Annex 6.4. Source: Authors' estimation using data from the Central Bank.

\section{Figure 33: The Effect of Import Protection of Sectoral Value Added}

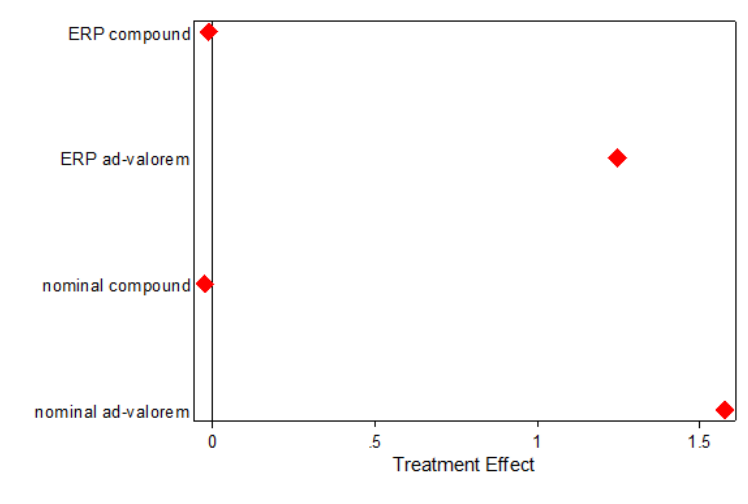

Note: The red diamond presents the estimated coefficients from fixed-effect regressions where the dependent variable is value-added growth and where the controls were the four different measures of import protection. Hollow diamonds represent coefficients that are not statistically significant at the 95 percent confidence interval. Results are shown in Annex 6.4.

Source: Authors' estimation using data from the Central Bank.

These negative impacts seem to be driven by widening productivity gaps within sectors, with less efficient firms being prevented from exiting the market. Employing the same empirical method outlined above, we estimate the correlation between the top and bottom tenth percentile of TFP within sectors with the protection variables (Annex 6.4). Results suggest that protection rates that account for the compound tariffs and other duties increase resource misallocation. Likewise, this protection structure reduces market concentration by allowing less efficient firms to remain in the market.

The overall results suggest that a rationalization of the compound tariffs and other import duties applied in Ecuador could have a positive impact on productivity growth through a reallocation of factors toward more productive industries. The current protection structure is

\footnotetext{
${ }^{24}$ In addition, effective compound tariffs appear to have a negative effect on sector-level exports. The channels through which import protection affects exports are many, but we have presented two in this section: low sectoral TFP and low value addition.
} 
leading to significant resource misallocation, with capital and labor remaining in sectors with limited growth potential instead of flowing into more productive sectors. This misallocation of factor of production generates lower value added and productivity growth. In addition, such compound tariffs increase uncertainty for importers. This is because final import costs depend on the volume or quantity-specific duties (weight for example) that can easily be subject to measurement errors (e.g. differences in calibration on weight at ports versus exporter warehouses) or to informal rents by government officials.

\subsection{Labor Market Regulations and Labor Productivity: the Achilles heel of firm competitiveness in Ecuador ${ }^{25}$}

Restrictive labor regulations are costly to firms and limit their ability to adjust to demand shocks. Labor regulations seek to protect workers by ensuring fair payment, minimum safety conditions, and coping mechanisms for employment termination. These objectives are frequently implemented through minimum wage policies, access to social security, and compensation for dismissal. While well-intended, these regulations may negatively affect firms' costs and incentives to hire workers formally. This could, in turn, limit workers' ability to find formal (protected) jobs (Kugler 2004). According to the World Economic Forum Global Competitiveness Report 2019, regulatory restrictions in the labor market represent an important binding constraint for firms. Ecuador underperforms in many dimensions of this ranking. Its worst ranking relates to the hiring and firing of workers, for which it ranks $136^{\text {th }}$ out of 140 countries. It also performs poorly for its flexibility in setting salaries ( $72^{\text {nd }}$ place), for the relationship between workers and employers $\left(76^{\text {th }}\right)$, and for the relation between workers' wages and productivity $\left(90^{\text {th }}\right)$. As discussed in more detail below, the lack of relation between wages and productivity marks one of the most significant constraints to creating formal jobs in Ecuador.

In Ecuador, labor market regulations have changed several times in the last two decades, alternating between periods of flexibility and periods of restriction. ${ }^{26}$ The introduction of Ecuador's dollarization regime in 2000 was accompanied by a reform (the Law of Economic Transformation) that simplified wage setting for the private sector by unifying various components of the remuneration packages (salary unification), such as extra wages, commissions, and in-kind payments. ${ }^{27}$ This implied broadening the base for social security contributions and personal income taxes (based on wage levels). The reform also introduced flexible hiring methods, such as hourly and temporary contracts. However, many rigidities remain in place. These included the structures for setting the minimum wage, for establishing firing costs, and for agreeing profit sharing among

\footnotetext{
${ }^{25}$ Prepared by Ivan Gachet, Consultant, GMTLC. May 2019.

${ }^{26}$ The main labor regulations in Ecuador are the Constitution, the Labor Code, Social Security Law, and the Human Mobility Act. The entities responsible for enforcing and implementing labor regulations are the Ministry of Labor and Social Security.

${ }^{27}$ Before 2000, the remuneration packages included four categories of extra wages, commission payments, cost of living compensation, and others.
} 
workers. In 2001, changes to the Social Security Law made all workers contribute to the social security system regardless of the nature of their contracts. To some extent, this equalized the contractual obligations of workers hired directly by firms and those hired through temporary agencies (Giugale, Fretes-Cibils and Somensatto 2008; IMF 2006). The immediate effect, however, was an increase in the numbers of workers affiliated to the social security system.

A reversal of the flexibilization reforms of the early 2000 s began in 2008 . In this year, hourly contracts were prohibited, as were all forms of intermediation and outsourcing. In 2015, the Law for Labor Justice introduced ceilings for firms on profit-sharing and on wages paid to senior executives. Mandatory severance payments for workers voluntary resigning from their jobs were also brought in and fixed-term contracts were eliminated. Finally, in 2016, the government started taking small steps to increase flexibility again. For example, the Law for Youth Employment established a new unemployment insurance program and a subsidized youth employment scheme. It also saw the introduction of temporary reductions in workers' hours for financially-strapped companies. On the flip-side, the new legislation imposed nine months of unpaid maternity or paternity leave. In 2018, the Ministry of Labor introduced new contract modalities for temporary workers in four sectors: flowers, bananas, tourism, and agriculture/livestock. Adoption by firms has been limited, however.

This chapter analyses the relationship between labor costs (wage and non-wage), labor productivity, and firm competitiveness. First, we review Ecuador's Labor Code and identify the main components of the country's labor costs. Then, we perform a comparative analysis of the main components of Ecuador's labor costs, including the cost of compliance with labor regulations and the cost of hiring formal workers. The study considers Ecuador's performance relative to that of other countries in the region. It also compares different sectors of the Ecuadorian economy. Finally, the analysis studies the elasticity of wage and non-wage costs of labor with respect to labor productivity. For this, it draws on a cross-section of firms from 2000 and 2015.

The main results of this chapter are summarized as follows: (i) labor market regulations in Ecuador have many constraints that limit the ability of firms to hire and fire workers. Tryout periods are also relatively short compared with other countries and costs of dismissal for fully engaged employees are prohibitive; (ii) the minimum wage is relatively high compared to other countries in the region. This is mainly due to the mechanism for setting the minimum wage, which is highly inefficient. Ecuador's minimum wage represents the main determinant of high labor costs as it serves as the base for calculating other benefits, (iii) the cost of hiring a formal worker in Ecuador is 1.3 times higher than average in Latin America. Hiring costs average around 41 percent of value added per worker, although the variance between sectors is high. In manufacturing, for instance, hiring costs average 27 percent of value added per worker, while for commerce the figure increases to 70 percent; (iv) the response of labor productivity to changes in the cost of labor (wage and non-wage) is negative and significant. The elasticity of wages with respect to labor productivity was -1.03 between 2000 and 2015, but this increased to 1.22 between 2008 and 2015 . The elasticity of non-wage costs of labor components is also negative and significant, although smaller in magnitude. 


\section{a. Labour Regulations in Ecuador}

In Ecuador, wage setting for the private sector is determined by the Basic Unified Minimum Wage, which includes a national minimum wage and minimum wages by sector and occupation. ${ }^{28}$ Minimum wages are decided through a bargaining process between workers, employers, and government representatives at the end of each year. If no agreement is reached in the negotiation process, which is usually the case, minimum wages are set by the Ministry of Labor. Once the national minimum wage is determined, the Sectorial Wage Councils meet to decide increases of sectoral minimum wages, including minimum wages by occupations within each sector. The convene worker representatives, private-sector employers, and the government. There are 22 such councils in total, although the number has been known to change (Wong, 2019). Sectoral minimum wages can differ widely for similar occupations, creating distortions in the labor market. For instance, the minimum wage for a manager in the telecommunications sector is 4.4 times higher than that of his or her peer working in finance. Such variations are evident in lowskilled sectors as well. The minimum wage for a diver in the transport sector, for instance, is 60 percent of the minimum wage to which a driver in the telecommunications sector is entitled (Ministerio de Trabajo, 2019). As a result, the minimum wage structure in the economy does not reflect differences in productivity either within or across firms. This uncompetitive wage-setting mechanism directly affects the competitiveness of the private sector, with small firms being especially hard hit. Were reforms to be introduced that simplified the mechanisms for setting the minimum wage and sectorial wages, then major distortions in the labor market could be eliminated.

International models could inform a transition by Ecuador to more efficient mechanisms for setting the minimum wage. A possible example is that of Costa Rica. This Central American country currently operates a multi-tiered minimum wage system that sets the minimum wage in line with workers' skill levels. Originally, Costa Rica's minimum wage system took account of differences not only in skill levels but also according to sector, region, and firm size. As a result, it counted 520 specific minimum wages by 1987. In an effort to reform this inefficient and unmanageable system, the Costa Rican government initiated a simplification process in 1992 that saw it merge occupations primarily according to skill level. Nowadays, the minimum wage structure considers only four main categories: unskilled, semi-skilled, skilled, and specialized workers. There are five additional rates that vary according to a worker's educational level (ILO, 2017). Chile presents another interesting model. The country has a single minimum wage system, with annual increases adjusted for expected inflation and average productivity increases. Within this single system, there are two national minimum wage levels; one for private-sector employees aged 18-65 years old, and another for workers under 18 years old and over 65 years old. Uruguay, meanwhile, has a system of minimum wages that includes a national minimum wage plus strong state involvement in collective bargaining through wage councils, like those in Ecuador. Uruguay currently has two institutional minimum wage mechanisms. The first is the national, government-

\footnotetext{
${ }^{28}$ India, South Africa, and Uruguay are countries with a similar wage structure to Ecuador.
} 
set minimum wage, which is paid to all private-sector wage employees aged over the age of 18 years old. The arrangement excludes rural and domestic workers. However, it is rarely applied because most industries fix their minimum wage level through collective bargaining. ${ }^{29}$ The second element of Uruguay's system is minimum wages negotiated in the wage councils for various industries. These include variation for occupations within these industries (Marinakis 2016).

As with other countries in Latin America, workers in Ecuador receive a bonus in the form of extra wages. The Christmas bonus or 'thirteenth' salary is equivalent to the average monthly wage in a year, including benefits, commissions, supplementary pay, and overtime pay. In addition, a school bonus or 'fourteenth salary' is paid before the beginning of the school year to help workers pay for school supplies and/or school tuition fees. This is equivalent to the basic unified minimum wage. In Argentina, a bonus is paid once a year as a one-off payment. This equates to a single month's wage. In Colombia, meanwhile, benefits are divided into two instalments, each one paid every six months. For these countries, benefits represent about 8 percent of wages, which is half the value for Ecuador. Chile is the only country in Latin America in which workers receive no bonus payment. The bonus paid in Ecuador is similar in size to the bonus paid in Panama and Peru, but double that of Argentina, Brazil, and Colombia (Alaimo, Bosch, \& Gualavisi, 2017). In 2015, the Law for Labor Justice established that workers could be paid thirteenth and fourteenth salaries in instalments throughout the year, instead of in lump sums. However, workers can opt out of this revised arrangement and continue to receive their payments in lump sums.

Until the end of the 1990s, Ecuador's Labor Code established additional benefits that were paid on top of wages to help workers cope with high levels of inflation during those years. The list of benefits included thirteenth, fourteenth, fifteenth, and sixteenth salaries, as well as costof-living compensation, a complimentary bonus, commissions, and a transportation bonus. The thirteen and fourteen salaries were paid as they are today (i.e. at Christmas and the start of the school year, respectively). The fifteenth salary, meanwhile, was paid in equal amounts in February, April, June, August, and October. As for the sixteenth salary, which was equivalent to one eighth of the base wage, this was paid every month (MacIsaac and Rama 1997). The other benefits were paid throughout the year. Collectively, they usually exceeded the base wage. Commissions alone were more than double base wages, for example, a fact that further distorted the labor market. The 2000 reform implemented a wage unification process that eliminated most extra wage benefits, with the exception of the thirteenth and fourteenth salaries. ${ }^{30}$

Current labor legislation entitles formal workers to receive 15 percent of the firm's net profits before taxes each year. Ten percent of profits are distributed equally to all workers regardless of their annual wages, while the remaining 5 percent is paid proportionally according

\footnotetext{
${ }^{29}$ In Uruguay, rural and domestic workers also have specific minimum wages. See: https://www.mtss.gub.uy/web/mtss/consejos-de-salarios.

${ }^{30}$ For details of the wage structure before and after the reform introduced by The Economics Transformation Law of 2000. See: https://www.derechoecuador.com/unificacioacuten-salarial.
} 
to a worker's dependents (e.g. spouse, children under 18 years old, and disabled children regardless of age). When an employee has worked in a firm for less than one year, payments are made proportional to his/her time in the firm. It is worth noting that the Labor Code excludes profits from the base wages when computing social security contributions. ${ }^{31}$

Only two other countries in the region have mandatory profit sharing; Mexico and Bolivia. In the case of Mexico, the rate of profits shared with the workers is set by the National Profit Commission. The rate is currently set at 10 percent of taxable revenue. Half of the profits to be shared are distributed according to the wages of each worker, while the other half is shared out equally among all workers in identical amounts. Contrary to Ecuador's legislation, where all firms are required to pay a share of profits, Mexican labor legislation exempts new companies from this obligation in their first year of operations. New companies in the mining sector are also exempted during the prospection stage, prior to the creation of revenues (Marinakis A. , 1999). In Bolivia, when a company makes annual profits, workers are entitled to receive one additional monthly salary, up to 25 percent of the firm's profits. When profits do not cover all workers, they are paid on a pro rata basis. Profit sharing is also practiced by many European companies, although they do so on a voluntary as a recognition of workers' performances (Freeman, 2008).

Mandatory payments to pensions fund, reserve funds, unemployment insurance and others social security contributions represent a large share of the cost of hiring formal workers. For most formal workers, mandatory contributions represent 20.6 percent of wages. This is covered by a contribution of 9.5 percent by workers and 11.2 percent by employers. ${ }^{32}$ These rates are below the average contributions paid by regional peers. ${ }^{33}$ Worker contributions in Ecuador are 2.5 percentage points lower than those for its peers, while employer contributions are 11.2 percentage points lower. Nearly half (47 percent) of total contributions is directed to pension funds, which are mostly funded by workers. Workers' pension contributions represent 6.6 percentage of their total contribution (see Table 12). This is 1.8 and 1.1 percentage points lower than the average contributions paid to pension funds from workers in regional peer countries and in dollarized peer countries, respectively. ${ }^{34}$ Only in Chile and Peru are contributions to the pension fund covered entirely by workers. Other funds covered by mandatory contributions are unemployment insurance, farmers' social insurance, healthcare, and indemnity in the event of workplace injury (see Table 12). The last two are covered entirely with contributions from employers. ${ }^{35}$

\section{Table 12: Distributions of Social Security Contributions}

\begin{tabular}{lll}
\hline Funds & Workers & Employer \\
\hline
\end{tabular}

\footnotetext{
${ }^{31}$ Labor Code, Art. 102.

${ }^{32}$ Contributions for independent workers are voluntary but are required to cover the total contributions of 20.6 percent of wages.

${ }^{33}$ Regional peers include Argentina, Brazil, Colombia, Chile. Mexico, and Peru. These countries were selected based on GDP per capita, population, and dependence on commodity revenues.

${ }^{34}$ Dollarized peers include Panama and El Salvador.

${ }^{35}$ Other countries also have mandatory contributions for health insurance, work injury, unemployment insurance or savings for unemployment, and family allowances (Alaimo, Bosch and Gualavisi 2017).
} 


\begin{tabular}{lcc} 
Pensions & $6.64 \%$ & $3.10 \%$ \\
Healthcare & & $5.71 \%$ \\
Work injury & $0.55 \%$ \\
Unemployment insurance & $2.00 \%$ & $1.00 \%$ \\
Farmer's social insurance & $0.35 \%$ & $0.35 \%$ \\
Organic Law for People with Disabilities & $0.10 \%$ & \\
Administration expenses & $0.36 \%$ & $0.44 \%$ \\
\hline Source: OECD 2016. \\
Employee Social Security contributions are levied on gross wages. Employer \\
contribution are applied to the payroll.
\end{tabular}

Unemployment insurance was introduced by the Law for Youth Employment in 2016 in order to protect formal workers against involuntary unemployment, but the mechanism could be improved. This fund is financed with contributions from workers and employees (see Table 12). Eligibility is based on having no less than 24 contributions - six of which must be consecutive - before becoming unemployed for 60 days or more. Unemployment insurance only covers workers who are fired from their jobs. Approval can take up to 45 days. Payments have a fixed and variable component. The fixed component is financed with the contributions from employers and is equivalent to one basic unified minimum wage. The variable component is financed by workers contributions and complements the fixed component up to 70 percent of a worker's average wage in the 12 months prior to becoming unemployed (Jara, 2018). Unemployment insurance payments are only made for five months, with a reduction of five percentage points each month. In this way, the unemployed worker reaches 50 percent of his or her wages when the benefit ends. The incentives and the structure of this insurance could be improved by making it easier to access and by reducing the time of the application process. Removing the requirement for workers to be unemployed for a month represents another potential improvement.

Ecuador could learn from other experiences in the region, such as in Chile, which has a mixed system of unemployment insurance financed by all three social actors (government, employers, and workers). The system in Chile generates two funding mechanisms. The first is an individual savings account for each worker. This is financed by contributions from both the worker and employer in the case of open-ended contracts. For workers with short-term contracts, only the employer contributes. The second mechanism comprises a solidarity fund financed by employers and fiscal contributions. Unemployed workers can only receive payments from the solidarity fund if their own savings are insufficient to cover their period of employment (Sehnbruch \& Carranza, 2014).

Labor legislation and constitutional constraints forbid contract modalities, limiting the flexibility of the labor market. In 2008, the Constitutional Assembly banned hourly contracts, as well as intermediation and outsourcing. The move was designed to prevent the negative impact of such employment mechanisms on working conditions and labor stability. Contracting workers through a third-party service provider (outsourcing) is only permitted in few specific cases.. In 2015, the Law for Labor Justice imposed additional constraints by banning fixed-term employment 
contracts that allow employers to hire a worker for one year with the possibility of renewing the contract for another year. ${ }^{36}$ Such contracts made workers vulnerable to being fired at any time without any compensation. The law also reduced the probation from 12 months to 90 days. Regional peers (excluding Chile and Colombia) also prohibit firms from imposing fixed-term contracts for permanent tasks. Such contracts are allowed for non-permanent tasks, however. One significant implication of the ban on fixed-term contracts is that workers become entitled to an indefinite contract after completing a probationary period. This marks an important difference with regional peers, where contract periods are often fixed. In the case of Chile and Brazil, contracts last 12 and 24 months, respectively. Colombia and Argentina are even longer, at 36 months and 60 months, respectively (Doing Business, 2019). In 2018, the Ecuadorian government established contracts with flexible hours for three sectors: tourism (up to 100 hours per month), flower production (40 hours, split over a six-day week) and banana production (100 hours per month). However, high costs and regulatory uncertainty have limited the adoption of these contractual forms.

Ecuador has the highest dismissal cost of workers in Latin America. Severance payment for a worker with five years of tenure is twice as high as the Latin American average and 1.52 higher than the average for regionals peers (Doing Business 2019). Ecuador's Labor Code obliges employers to pay a severance bonus whenever an employment relationship ends, even in the event of the worker resigning. The size of the severance payment is 25 percent of the worker's last monthly wage for each year of service. When a dismissal occurs without a justified cause, severance payments also include a compensation equivalent. This amounts to three months of wages in the case of workers with fewer than three years in the company. For those that have worked more than three years, they are entitled to one month of salary per year of service, up to a maximum of 25 monthly wages. This implies that compensation for dismissal increases with the duration of services. As a consequence, it is very expensive for firms to fire long-term workers, which represents a constraint to their competitiveness.

In other Latin American countries, severance payments vary by tenure and in some cases by salary range ${ }^{37}$ For instance, private sectors workers in Chile are entitled to a severance payment equivalent to the last month of wages per year of services up to a maximum of 11 years, although not exceeding 90 UF. ${ }^{38}$ In Colombia, severance payments depend on a combination of a worker's tenure and final wage. For workers earning less than ten times the legal minimum wage, compensation is equivalent to 30 days of salary for the first year of service and 20 days of salary

\footnotetext{
${ }^{36}$ Current labor legislation allows some forms of contracts that are similar to a fixed-term employment. These include: piecework contracts for specific work that is part of the course of the business; incidental contracts for satisfying an employer's special demands (e.g. replacing personnel on leave); casual contracts for attending to urgent or special needs not related to the employer's regular business up to 30 days; days-in-a-year contracts; and contracts on a jobby-job basis.

37 A complete description of severance payments legislation in other countries can be found at https://www.oecd.org/employment/oecdindicatorsofemploymentprotection.htm

${ }^{38} \mathrm{UF}$ is a Chilean currency unit indexed according to inflation.
} 
for each additional year. For those earning more than ten minimum wages, severance payment is equivalent to 20 days of salary for the first year of service and 15 days of salary for each additional year. In Uruguay, meanwhile, dismissal compensation is equivalent to a single month's wage per year or per fraction of a year worked, with a ceiling of six monthly instalments. The system in Brazil, on the other hand, is completely different. Here, the Labor Code establishes that employers should open an individual banking account for each worker when he or she is hired (Fundo de Garantia por Tempo de Serviço). This account is then funded by monthly deposits equivalent to 8 percent of the worker's wage. Should that worker be dismissed, then he or she has access to funds accumulated in their accounts (Jaramillo \& Saavedra, 2005).

\section{b. Cost of Labor}

Labor costs in Ecuador have increased over the last twelve years, but labor productivity has not improved, resulting in a loss of competitiveness relative to other countries in the region. Between 2006 and 2014, the ratio of wages of formal workers to GDP decreased from 0.57 to 0.50 . This means that labor productivity rose about 2.3 times faster than labor costs, reducing the relative labor cost per unit of labor by half. However, this trend reversed after the slowdown of the economy following the collapse in oil prices, returning to 0.56 in 2017. Ecuador's experience compares markedly to most of its regional and dollarized peers, where the ratio of wages to average productivity improved over a similar period. In Colombia, for instance, wages to GDP per worker decreased from 0.54 to 0.49 between 2006-2017. In Peru, meanwhile, the ratio fell from 0.75 to 0.55. For Panama, the decline was 0.48 to 0.37 (Figure 34). Several reasons exist for Ecuador's anomalous performance. The first relates to the plunge in oil prices. This event caused average productivity in Ecuador to decrease by 10.8 percent. In contrast, productivity increased at this time in Colombia and Peru by 3.6 percent and 5.6 percent, respectively. Only Brazil shows a decline in labor productivity during this period. Even then, however, the decline of GDP per worker was only one third of that registered in Ecuador. The second reason is that the country's economic slowdown was not accompanied by a downward adjustment in formal wages. Indeed, formal wages continued to increase after the fall in oil prices.$^{39}$ It can be safely surmised that Ecuador's competitiveness in relation to its peers was seriously impacted during this recent period.

\section{Figure 34: Ratio of Average Labor Income of Formal Workers to GDP per Worker}

Panel A: Regional Peers

Panel B: Dollarized Peers

\footnotetext{
${ }^{39}$ Wages for the economy as a whole might have adjusted partially in light of worker migration from the formal to the informal sector.
} 


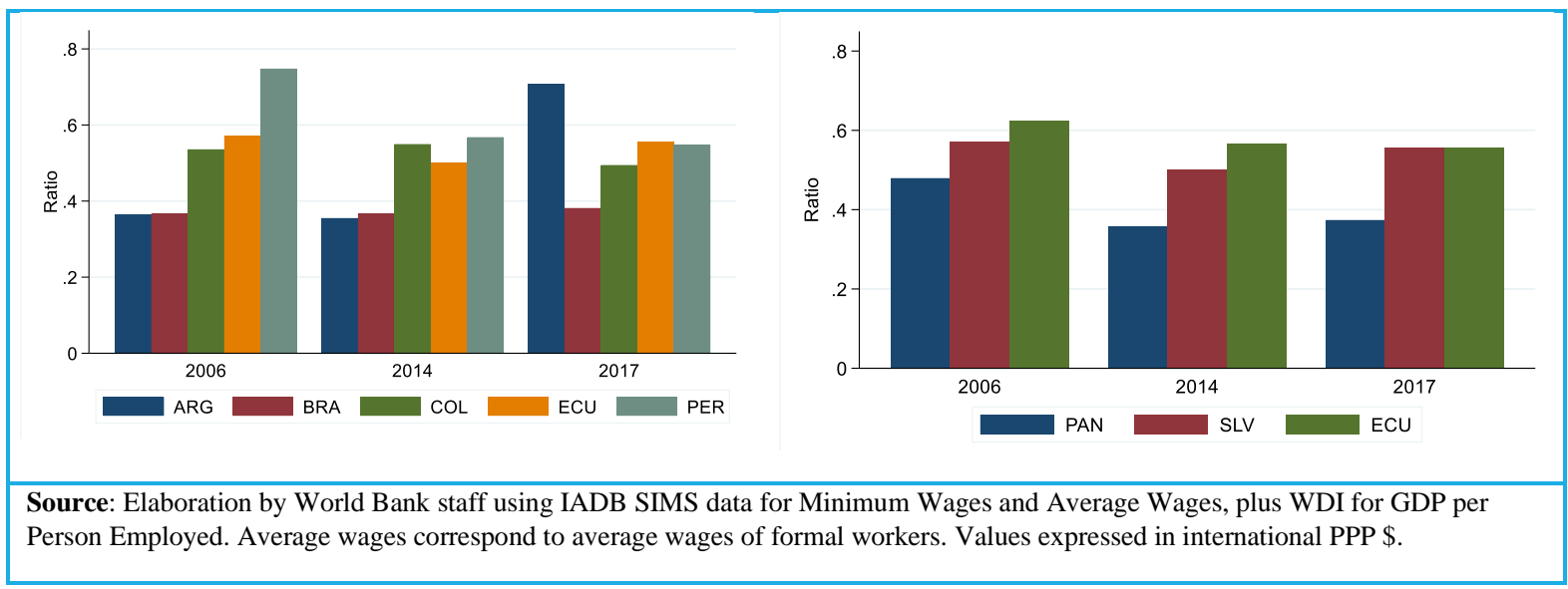

Countries with higher labor wage costs relative to their productivity tend to be unable to compete and frequently resort to informality as a way to attenuate labor costs, ultimately harming growth; Ecuador is no exception here. According to official estimates, about half of Ecuadorian workers are employed in the informal sector. These workers do not contribute to social security nor do they have access to it. They do not receive any of the mandatory benefits of formal employment either. On the flipside, they pay no tax on their earnings. ${ }^{40}$ Finally, empirical evidence shows a negative and significant relationship between informality and growth. For instance, Loayza (2007) carried out a cross-country regression of average growth rates on informality growth for a sample of 100 countries over a 20-year period. The study found that informality leads to a decline in the rate of growth of between one and two percentage points. However, this relationship tends to disappear when additional controls are included in the regression, such as education, financial debt, or corruption (Oviedo, 2009).

\section{Figure 35: Ratio of Minimum Wages to Average Labor Income of Formal Workers}

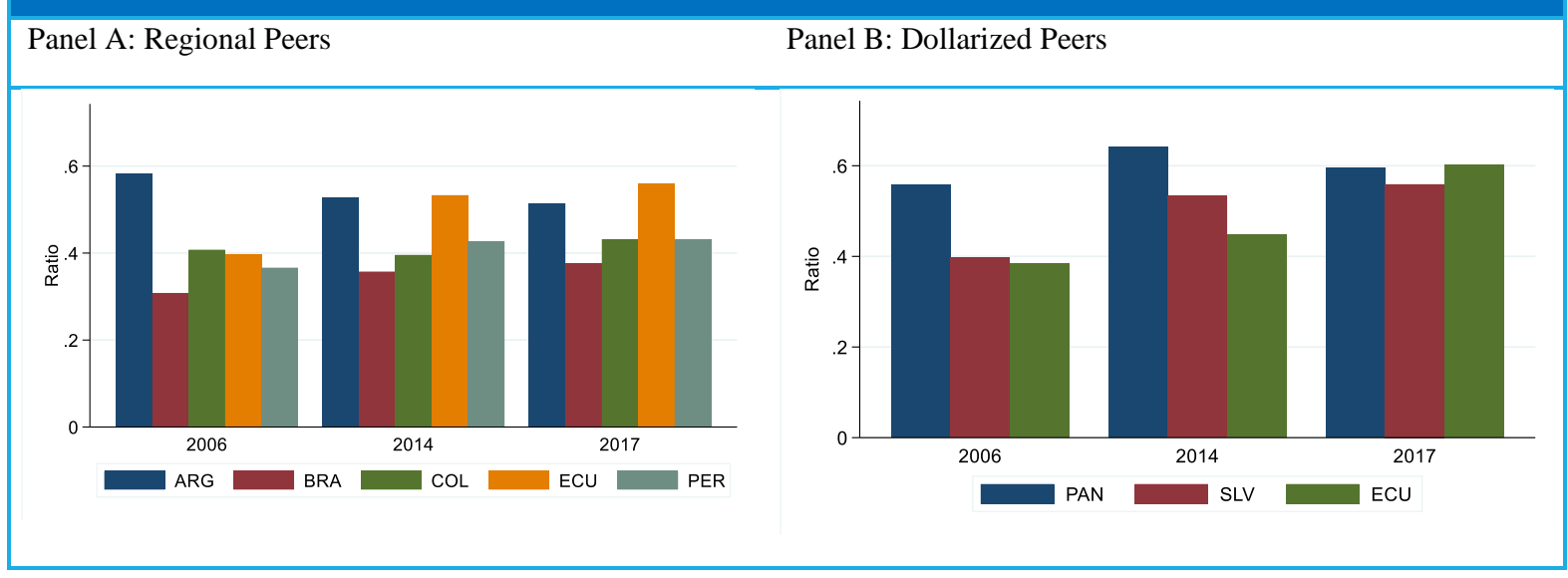

${ }^{40}$ Perry et al. (2007) have a complete discussion on the direct and indirect effect of informality in Latin American countries. 
Ecuador's formal wage dynamics were largely driven by the minimum wage, which is relatively high compared to other countries in the region. Between 2006 and 2017, the share of the minimum wage to the average wage of formal workers increased from 40 percent to 50 percent. This share is ten percentage points higher than for regional peers on average, but three percentage points lower than the average for dollarized peers in 2017 (Figure 35). The reason is that Ecuador's minimum wage is higher and grew at a faster rate than in peer countries (see below). Between 2006 and 2017, Ecuador's monthly minimum wage in real terms (2011 PPP) increased from $\$ 368$ to $\$ 567$. By comparison, it rose in Colombia from $\$ 424$ to $\$ 483$ and in Peru from $\$ 370$ to $\$ 446$. During the same period, average wages in Ecuador rose 11 percent in real terms, which is two percentage points higher than the growth of wages in Colombia and Peru. However, no significant difference exists in averages wages between these three countries. In 2017, for example, average wages in Ecuador were \$1,030 in real terms (2011 PPP), whereas in Colombia and Peru they were $\$ 1,119$ in $\$ 1,034$, respectively. Increases in the minimum wage, as occurred in Ecuador, not only affect labor costs and firms' competitiveness; they also have an adverse effect on formal employment for individuals at the bottom of the wage ladder, such as young and unskilled workers. According to the Systematic Country Diagnostic, the share of informal workers who earn less than the minimum wage has increased continuously. In 2017, it had reached almost three-fifths of the working population (World Bank 2018).

The minimum wage in Ecuador has been increasing steadily and at a faster rate than its peers since 2005, growing 82 percent in real terms. This increase is the highest among regional and dollarized peers. During the same period, the minimum wage in real terms increased in Chile and Brazil by 76 percent and 65 percent, respectively. In Colombia and Panama, the increase has been much more modest, at below 50 percent (Figure 36). The minimum wage in PPP terms in Ecuador is also the highest among its peers, with the exception of Panama. Mexico's minimum wage is 35 percent that of Ecuador, for example. The comparison in Peru is closer, yet its minimum wage rate is still only 77 percent that of Ecuador's. Only Chile's minimum wage is about the same as that of Ecuador. Yet it is important to note that GDP per worker in Chile is more than double that of Ecuador. This implies that the structure for setting the minimum wage in Ecuador fails to relate to the economy's average productivity and generates large distortions in the labor market. In addition, most of the mandatory contribution (e.g. bonus and severance payments) in Ecuador is computed according to workers' wages. This means that non-wage costs of labor increase follow wage (or minimum wage) dynamics on a yearly basis, further undermining firms' competitiveness. Ideally, it would be possible to identify empirical evidence about the effect of minimum wages on firms' productivity and competitiveness so as to calibrate a country's optimal minimum wage level and to guide future increases. In Ecuador's case, however, such evidence is not available. Even so, it is clear that current levels are high and distortive. Similarly, it is evident that efficiency gains would emerge from the elimination of the country's ballooning wage levels. 


\section{Figure 36: Minimum Wage Growth}

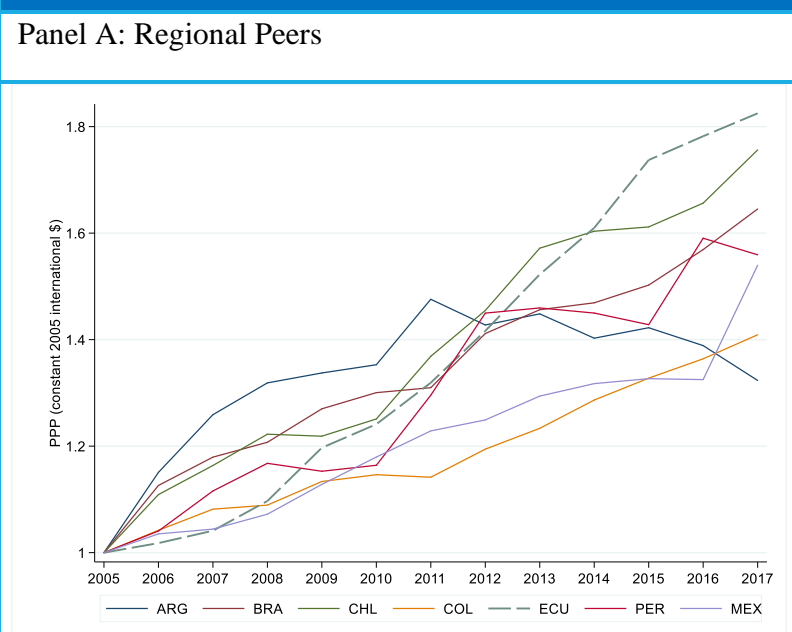

Panel B: Dollarized Peers

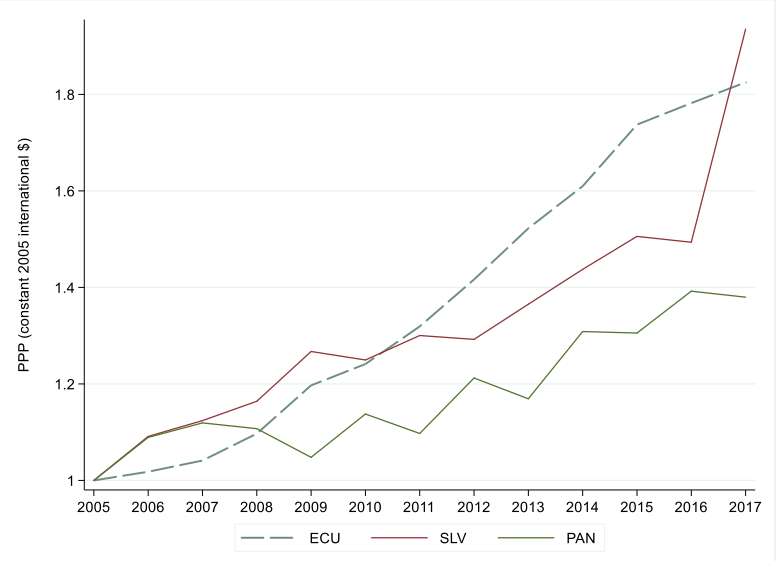

Source: Estimations by World Bank staff using ILO's minimum wage harmonized data and countries' labor legislation. For Panama and El Salvador, we complete the series for 2014-2017 using minimum wages growth rates computed from IADB's SIMS data.

While the effects of Ecuador's minimum wage increases were relatively small during the commodity boom, they amplified significantly during the economic slowdown. Aguiar and Castro (2015) analyze the impact of minimum wages in poverty and labor participation using labor surveys from 2013 to 2014 . They find that an increase of 1 percent in the minimum wage reduces poverty by 1.85 percent and increases labor participation by 1 percent. Wong (2019) estimates a difference-in-difference model to assess the impact of the increase in minimum wages in 2012, relying on the exogenous variation of sectoral minimum wages. She compares workers who receive the minimum wage as part of their wages (i.e. self-employed, business owners, and government workers) with those who only receive the minimum wage (i.e. formal sector workers). She found that an increase of 1 percent in minimum wages increases formal workers' wages by 0.5 percent. The effect on wages for women, however, was lower. A one-percent increase, meanwhile, was shown to have a positive effect for young workers. ${ }^{41}$ However, neither study controls for the positive effects of favorable economic conditions on the demand of formal workers for higher wages during these years. In fact, as economic activity slowed down, informality increased sharply, which suggests that labor costs in the formal sector could no longer be met by Ecuadorian firms. Further work needs to be done to understand the effects of minimum wages in Ecuador in different outcome areas (e.g. competitiveness). Any future research should also be oriented towards redesigning the mechanism for setting the minimum wage, ensuring that the dynamics of the labor market and the economy are properly accounted for.

\footnotetext{
${ }^{41}$ Brown (1999) reviews of the empirical evidence on the effects of the minimum wage on employment and other employment-related outcomes for developed countries.
} 
In Ecuador, the average cost of complying with labor regulations (i.e. non-wage costs) is higher than for most of its peer countries. As discussed earlier, the non-wage costs associated with ensuring that a formal worker complies with labor regulations include mandatory contributions, bonus payments, annual leave, severance payment, and firing notice (Alaimo et al. 2017). ${ }^{42}$ Total non-wage costs in Ecuador represent 2.3 percent of GDP per worker, which is 0.6 percent above the average in Latin America (Figure 37). Most of the non-wage cost as a share of GDP per worker is determined by mandatory contributions ( 1.2 percent) and bonuses ( 0.6 percent). It is worth noting that the cost of complying with labor regulations as a share of GDP per worker in Ecuador is similar to the cost in Argentina, Brazil and Colombia. For the remainder of Ecuador's regional and dollarized peers, compliance costs are lower, with the exception of Peru (where the costs exceed those of Ecuador). ${ }^{43}$ Chile has the lowest cost of compliance and is also the country with the most flexible labor market in the region. Reducing the cost of regulatory compliance could significantly improve labor market outcomes for Ecuador. Colombia offers an illustrative example. In 1990, reforms to labor rules led to a reduction in dismissal costs. According to Kugler (2004), this helped contribute to a reduction of 10 percent in unemployment. ${ }^{44}$ Notably in the case of Ecuador, non-wage mandatory contributions are computed as a fixed rate of wages. This makes non-wage costs increase at the same rate as wages, which goes a long way to explaining the country's rising cost of labor over the last two decades. In fact, when calculated as a share of GDP, non-wage contributions in Ecuador are among the highest in the region.

\section{Figure 37: Non-Wage Cost as Percent of GDP per Worker}

Panel A: Regional Peers

Panel B: Dollarized Peers

\footnotetext{
42 This data was taken from (Alaimo, Bosch and Gualavisi 2017) which is the most recent study of labor cost in Latin America. Wage and non-wage structure of labor are computed revising legislation in most Latin American for 2013.

${ }^{43}$ If calculated as a share of average wages, non-wage costs look lower than in peer countries. This is because average wages are significantly higher in Ecuador.

${ }^{44}$ Other studies have shown that non-wage cost could reduce employment and have a substantial impact on the distribution of employment and on turnover rates affecting the most young and unskilled workers (see Heckman and Pages 2004; Botero et al. 2004).
} 

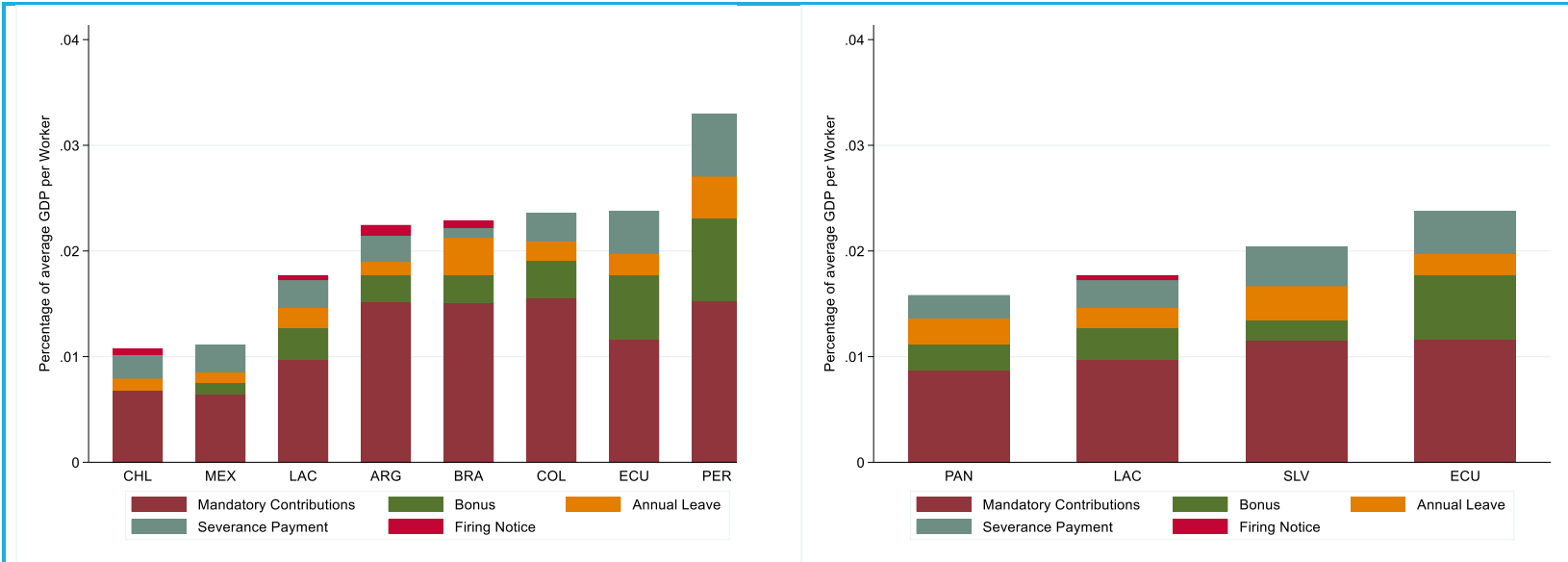

Source: Elaboration by World Bank staff using Alaimo et al. (2017) data for 2013. Contributions are calculated as share of GDP per worker, excluding benefits.

The total minimum cost of hiring a formal worker in Ecuador as a percentage of GDP per worker is $\mathbf{1 . 3}$ times higher than the average for Latin America. The total minimum cost of formal workers as a percentage of GDP per worker should be interpreted as the annual US dollar value of paying a worker the minimum wage plus all mandated non-wage contributions as a share of GDP per worker. This cost is computed by applying all the mandatory contributions to the minimum wages in real PPP terms. It represents a lower-bound estimate of the cost of formal workers relative to the average labor productivity. This approach also captures the variation of the cost of hiring workers across countries (Alaimo et al. 2017). Using this methodology, the average cost of formal labor in Ecuador is revealed to be 45 percent of GDP per worker. This is similar to the cost in Peru, but 12 percentage points higher than in Colombia. The difference is even larger when compared to Mexico, Brazil, and Chile, for which the total minimum cost of labor is below 30 percent of GDP per worker (Figure 38). As discussed, the minimum wage in real PPP is the main determinant of the total cost of formal labor, ranging from 29 percent of GDP per worker in Ecuador to 15 percent in Chile (the proportions for Peru and Colombia are 26 percent and 22 percent, respectively). Non-wage costs are also high in Ecuador and Peru, representing 15 percent and 17 percent of GDP per worker, respectively. This compares to an average of 26 percent for Latin America and the Caribbean. The fact that wage and non-wage costs are higher relative to productivity could explain why the rates of formal job creation in Ecuador are low. For instance, Alaimo et al. (2015) estimate that an increase of 10 percent in the total cost of hiring a formal worker (i.e. minimum wage plus non-wage cost) is associated with a decrease of five percentage points in the number of formal workers in Latin America.

\section{Figure 38: Total Cost of Formal Workers as Percentage of GDP per Worker}




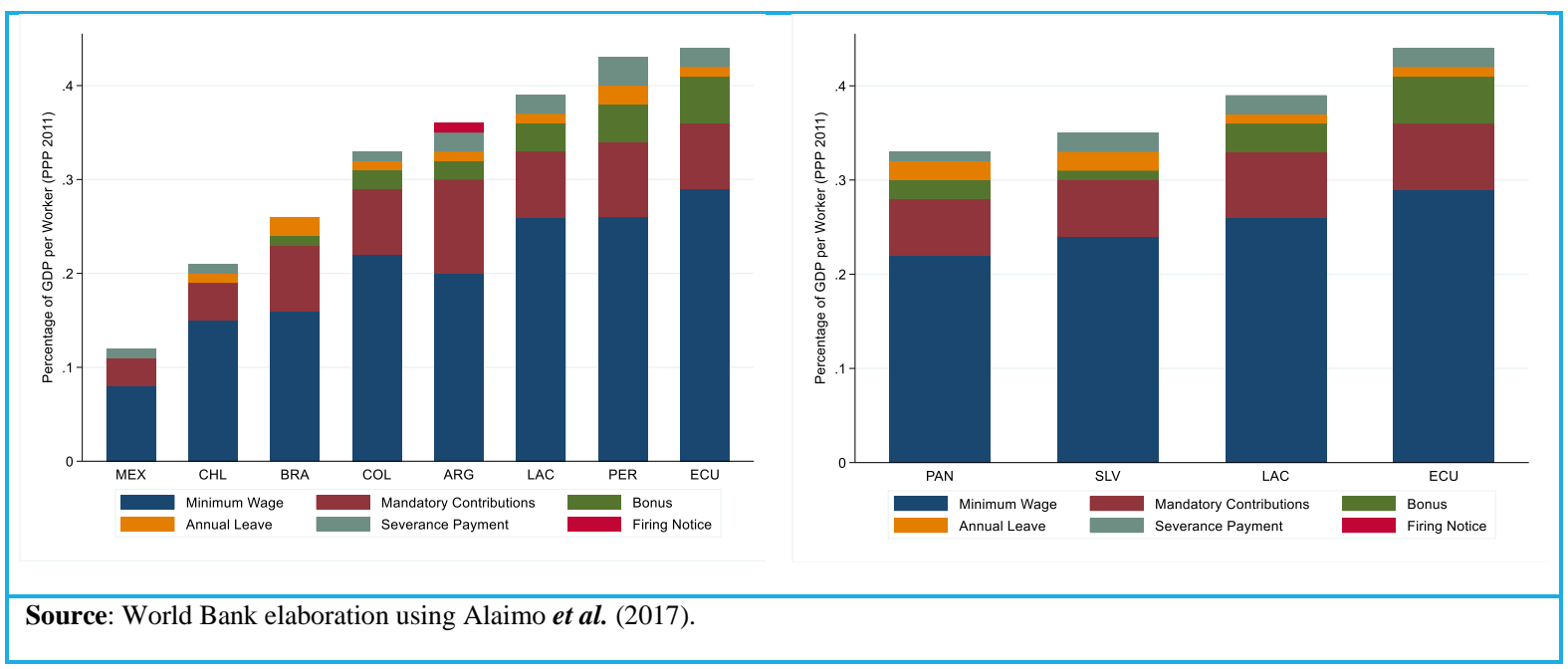

\section{c. Cost of Formal Labor Across Industries}

Since 2007, most wage and non-wage costs have increased significantly across industries. Labor costs in real terms increased modestly between 2001 and 2007 but have more than doubled since then (Panel A-Figure 39). There are important differences in the evolution of labor costs across sectors, particularly in the latter period. For example, in manufacturing, which is a relatively capital-intensive sector, labor costs have risen at a rate slightly below the average of the economy (excluding profits). In services and commerce payments, meanwhile, the rise in costs was driven by a seven-fold increase in social security, which caused firms to more than double their mandatory contribution payments during this period. This indicates that the implementation of greater control by the Ministry of Labor positive affected the formalization of workers in these sectors. In addition, in-kind benefits, such as transport, clothing, and lunch, increased modestly between 2001 and 2015. This suggests that firms could have adjusted labor costs to contain these benefits (see below).

\section{Figure 39: Real Growth of Wage and Non-Wage Components}

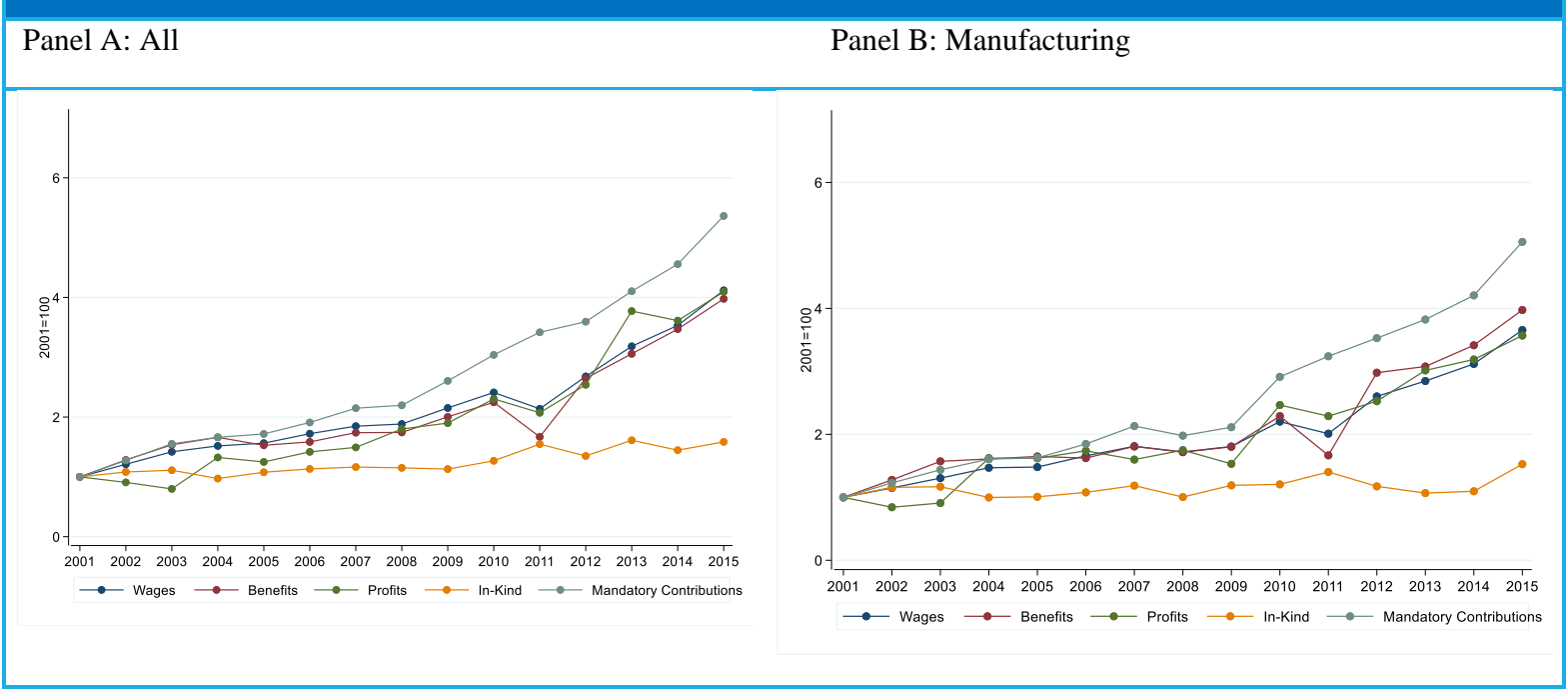




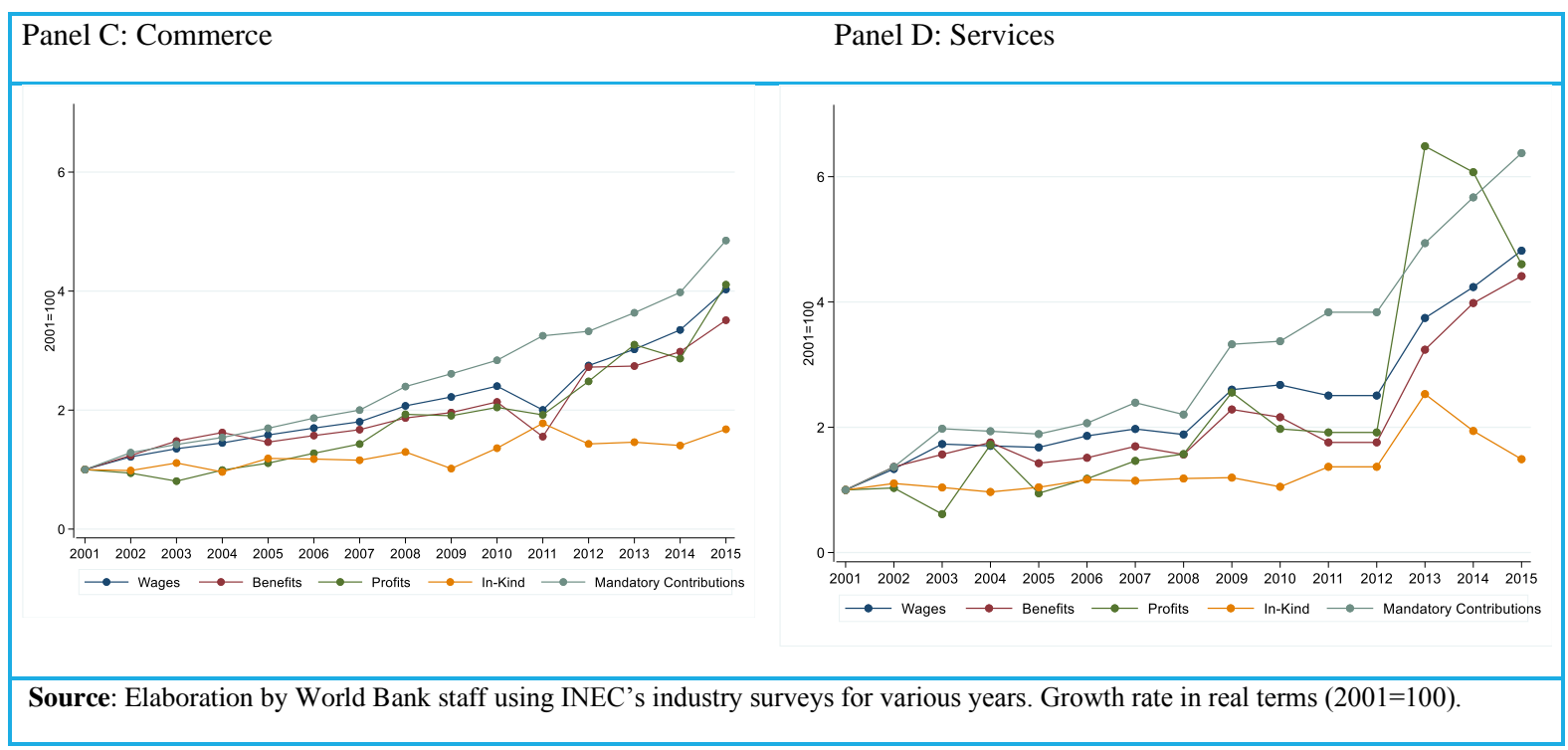

There are significant differences across sectors in the total cost of hiring formal workers as a percentage of value added per worker. ${ }^{45}$ In manufacturing, the total cost of formal workers relative to average labor productivity averaged 19 percent of value added per worker between 2001 and 2015. This is nine percentage points lower than the average cost of hiring a worker in services and 23 percentage points lower than the cost of labor in commerce during the same period. This is to be expected as manufacturing is a capital-intensive sector. Commerce has the highest cost of labor, reaching 82 percent of value added per worker in 2015. This represent an increase of more than three times the cost of labor in this sector between 2001 and 2015 (Figure 40). The increase of labor cost in commerce arose from the slowdown of the economy and the contraction of labor demand, which drove the sector's growth during the oil-price boom and which explains the relatively high share of wages relative to average productivity within the sector. Between 2001 and 2015, value added per worker decreased by 42 percent, while average wages in real terms more than doubled in commerce. Non-wage costs were also higher in commerce, representing 19

\footnotetext{
45 Wage and non-wage cost of labor were computed using information from labor surveys in a similar way as those shown above, but with some notable differences. First, we included the share of profits as part of the non-wage cost of firms. The total share of profits paid to employees are reported in labor surveys. Second, we worked with total wages and non-wages reported by a sample of firms in the manufacturing, commerce, and services sectors. Third, we considered severance payment as part of the in-kind category. One advantage of using industry surveys is that we could look at the dynamics of labor costs over two decades, including changes introduced by the labor reforms of 2000. For wage and non-wage costs computed in real terms, see Appendix. We computed the average cost of labor as a percentage of value added, instead of GDP per worker. We used value added per worker for each sector employing value-added data published by Central Bank and we computed the number of workers by sector using Gachet et al. (2018). Datasets for labor-related taxes were created using labor surveys from 2001 to 2017. This should be interpreted as the annual U.S. dollar value of paying a worker his or her labor wages, plus all mandated contributions, as a share of value added per worker in each sector. This complements the results presented above because it not only shows the real cost of hiring a worker in the Ecuadorian economy, but it also allows us to compare the cost of labor of different sectors relative to their average productivity.
} 
percent of value added per worker. This is eight percentage points higher than non-wage costs in services and 11 percent higher than in manufacturing.

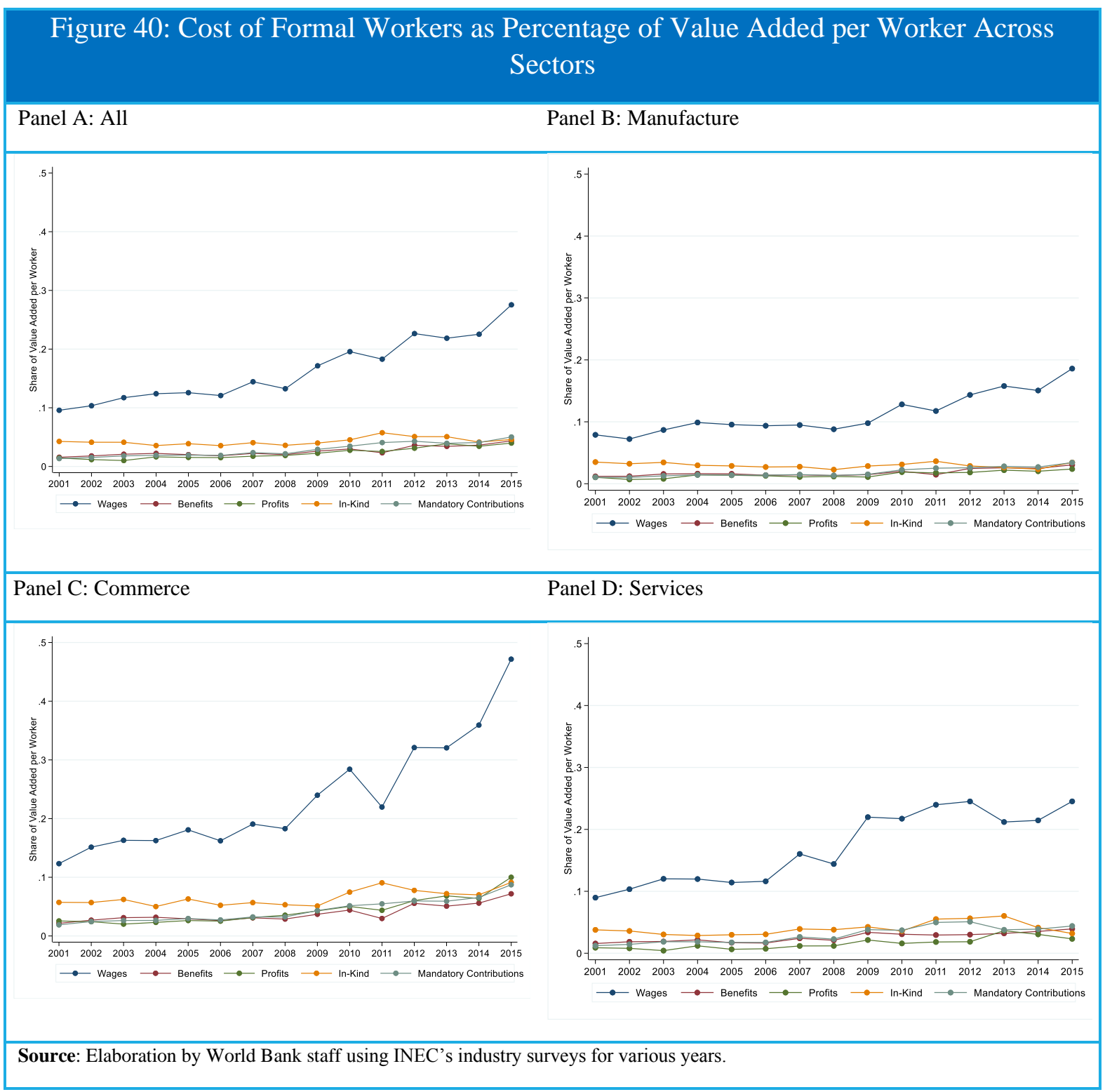

There is a significant and, in most cases, adverse effect of the cost of labor (wage and nonwage) on labor productivity. Table 13 shows the results of a pool linear (Ordinary Least Squares) regression of the log of value added per worker on the logs of wages, benefits, mandatory contributions, profits, and in-kind for a sample of firms in the manufacturing, commerce, and services sector from 2000 to 2015 . This table also presents results for a restricted sample of firms in two periods: from 2000 to 2007 (during which time flexible labor market regulations were introduced after dollarization) and from 2008 to 2015 (when restrictive labor regulations came into 
force; see above). All specifications in Table 13 control for firms' characteristics, sales as a share of total sales within each sector, and dummies for the 2000 and 2008 labor reforms as well as the 2015 safeguards. It should be noted that the relationship between the cost of labor and labor productivity is not necessarily causal as the latter can also be affected by institutional factors (e.g. rule of law), underdeveloped financial markets, increased competition in the international labor markets, and weak economic growth. ${ }^{46}$ In addition, it is difficult to isolate the effects of labor market regulation on labor productivity from the impact of other macroeconomic factors. Taking into account these considerations, the overall effect of wages on worker productivity is found to be negative and significant. Specifically, our calculations indicate that an increase of 1 percent in wages leads to a decline in labor productivity of 1.03 percent. Benefits and in-kind payments also negatively affect labor productivity, causing it to fall by 0.15 percent and 0.05 percent, respectively. The size of workers' share of profits and that of their mandatory contributions both have positive effects, but the magnitude of these effects does not upset the negative impacts of wages on labor productivity.

The negative effect of labor costs on labor productivity is higher in services than in other sectors. For instance, the elasticity of wages and labor productivity is -1.1 in services, -0.94 in manufacturing, and -0.87 in commerce. The negative relation between labor costs and productivity not only affects firms' competitiveness and constrains the creation of formal jobs, but it also limits the possibility of firms competing in the international market. However, improving competitiveness is related to factors other than just labor costs. These include the presence of strong institutions, access to capital markets, and productive investments. If introduced, these minimum institutional and economic requirements could sustain higher costs of labor while also maintaining competitiveness.

\section{Table 13: Wage and non-wage elasticities}

\footnotetext{
${ }^{46}$ Analyzing the effects of these factors in productivity are above the scope of this chapter.
} 


\begin{tabular}{|c|c|c|c|c|c|c|c|c|c|c|c|c|}
\hline & \multicolumn{4}{|c|}{ Full sample } & \multicolumn{4}{|c|}{ 2000-2007 } & \multicolumn{4}{|c|}{ 2007-2015 } \\
\hline & All & Manufacture & Commerce & Services & All & Manufacture & Commerce & Services & All & Manufacture & Commerce & Services \\
\hline Log of wages & $\begin{array}{c}-1.033^{* * *} \\
(0.026)\end{array}$ & $\begin{array}{c}-0.937 * * * \\
(0.037)\end{array}$ & $\begin{array}{c}-0.874 * * * \\
(0.048)\end{array}$ & $\begin{array}{c}-1.115^{* * *} \\
(0.056)\end{array}$ & $\begin{array}{c}-0.865^{* * *} \\
(0.031)\end{array}$ & $\begin{array}{c}-0.802 * * * \\
(0.044)\end{array}$ & $\begin{array}{c}-0.649 * * * \\
(0.058)\end{array}$ & $\begin{array}{c}-0.988^{* * *} \\
(0.068)\end{array}$ & $\begin{array}{c}-1.222 * * * \\
(0.042)\end{array}$ & $\begin{array}{c}-1.195^{* * *} \\
(0.062)\end{array}$ & $\begin{array}{c}-0.988^{* * *} \\
(0.078)\end{array}$ & $\begin{array}{c}-1.217^{* * *} \\
(0.098)\end{array}$ \\
\hline Log of Benefits & $\begin{array}{c}-0.155^{* * *} \\
(0.014)\end{array}$ & $\begin{array}{c}-0.088^{* * *} \\
(0.021)\end{array}$ & $\begin{array}{c}-0.147^{* * *} \\
(0.023)\end{array}$ & $\begin{array}{c}-0.291 * * * \\
(0.032)\end{array}$ & $\begin{array}{c}-0.082^{* * *} \\
(0.017)\end{array}$ & $\begin{array}{l}-0.039 \\
(0.024)\end{array}$ & $\begin{array}{c}0.005 \\
(0.029)\end{array}$ & $\begin{array}{c}-0.255^{* * *} \\
(0.040)\end{array}$ & $\begin{array}{c}-0.258^{* * *} \\
(0.021)\end{array}$ & $\begin{array}{c}-0.168^{* * *} \\
(0.038)\end{array}$ & $\begin{array}{c}-0.356^{* * *} \\
(0.034)\end{array}$ & $\begin{array}{c}-0.297^{* * *} \\
(0.050)\end{array}$ \\
\hline Log of $15 \%$ profits share & $\begin{array}{c}0.232^{* * *} \\
(0.007)\end{array}$ & $\begin{array}{c}0.169^{* * *} \\
(0.010)\end{array}$ & $\begin{array}{c}0.282^{* * *} \\
(0.012)\end{array}$ & $\begin{array}{c}0.250^{* * *} \\
(0.019)\end{array}$ & $\begin{array}{c}0.180^{* * *} \\
(0.010)\end{array}$ & $\begin{array}{c}0.131^{* * *} \\
(0.013)\end{array}$ & $\begin{array}{c}0.226 * * * \\
(0.017)\end{array}$ & $\begin{array}{c}0.204^{* * *} \\
(0.026)\end{array}$ & $\begin{array}{c}0.290 * * * \\
(0.009)\end{array}$ & $\begin{array}{c}0.257^{* * *} \\
(0.015)\end{array}$ & $\begin{array}{c}0.324^{* * *} \\
(0.016)\end{array}$ & $\begin{array}{c}0.263^{* * *} \\
(0.025)\end{array}$ \\
\hline Log of in-kind & $\begin{array}{c}-0.065^{* * *} \\
(0.007)\end{array}$ & $\begin{array}{c}-0.077^{* * *} \\
(0.011)\end{array}$ & $\begin{array}{c}-0.026^{* *} \\
(0.010)\end{array}$ & $\begin{array}{c}-0.057^{* * *} \\
(0.016)\end{array}$ & $\begin{array}{c}-0.097^{* * *} \\
(0.010)\end{array}$ & $\begin{array}{c}-0.112^{* * *} \\
(0.016)\end{array}$ & $\begin{array}{c}-0.041^{* *} \\
(0.017)\end{array}$ & $\begin{array}{c}-0.092 * * * \\
(0.022)\end{array}$ & $\begin{array}{l}-0.006 \\
(0.009)\end{array}$ & $\begin{array}{l}-0.016 \\
(0.012)\end{array}$ & $\begin{array}{l}0.022 * \\
(0.013)\end{array}$ & $\begin{array}{l}-0.008 \\
(0.021)\end{array}$ \\
\hline Log of mandatory contributions & $\begin{array}{c}0.337^{* * *} \\
(0.025)\end{array}$ & $\begin{array}{c}0.248^{* * *} \\
(0.034)\end{array}$ & $\begin{array}{c}0.295^{* * *} \\
(0.044)\end{array}$ & $\begin{array}{c}0.458^{* * *} \\
(0.058)\end{array}$ & $\begin{array}{c}0.271^{* * *} \\
(0.030)\end{array}$ & $\begin{array}{c}0.250^{* * *} \\
(0.041)\end{array}$ & $\begin{array}{c}0.175^{* * *} \\
(0.052)\end{array}$ & $\begin{array}{c}0.408^{* * *} \\
(0.074)\end{array}$ & $\begin{array}{c}0.359 * * * \\
(0.041)\end{array}$ & $\begin{array}{c}0.235^{* * *} \\
(0.062)\end{array}$ & $\begin{array}{c}0.311^{* * *} \\
(0.075)\end{array}$ & $\begin{array}{c}0.323^{* * *} \\
(0.094)\end{array}$ \\
\hline Firm controls & Yes & Yes & Yes & Yes & Yes & Yes & Yes & Yes & Yes & Yes & Yes & Yes \\
\hline Reforms dummies & Yes & Yes & Yes & Yes & Yes & Yes & Yes & Yes & Yes & Yes & Yes & Yes \\
\hline
\end{tabular}

Observations

The dependent variable in all regression is the log of value added per worker. Firms controls include logs of operational and fuel cost, indirect taxes and gross capital formation. Reforms dummies vinclude a dummy for the reform of 2000 equals to 1 between 2000 and 2005 (time of implementation) and zero otherwise, a dummy for the reform of 2008 equals to 1 in 2008 and zero otherwise, and a dummy for safeguards implemented in 2015 equal to one in 2015 and zero otherwise. firms sales as a share of totals sales within each sector. Robust standard errors in parenthesis. ${ }^{*} p<0.1 * * p<0.05 * * * p<0.01$

The negative effect of labor costs on labor productivity increased following labor reforms introduced after 2008. The elasticity of wages with respect to labor productivity went from -0.86 between 2000 and 2007 to -1.22 between 2008 and 2015. This represents an additional 40 percent loss in labor productivity for a one percent increase in wages since 2008. The negative effect of non-wage labor costs on productivity also increased during the same period. This indicates that the pro-worker labor policies implemented between 2008 and 2015 were insufficient to increase productivity and strengthen competitiveness. In addition, labor costs - and wages, in particular are not reflecting workers productivity. This, in turn, constrains firms' ability to grow and to generate formal jobs. These results are consistent with research by Besley and Burgess (2004), who study the effects of labor regulations on productivity, investment, employment, and poverty in India. The pair found that pro-worker labor regulation resulted in lower output, employment, investment, and productivity in the formal manufacturing sector.

\section{d. Conclusions and Policy Recommendations}

In Ecuador, the high costs and restrictiveness of labor market regulations are undermining competitiveness and encouraging informality. Labor costs are relatively high compared to other countries in the region. The mechanism for setting the minimum wage is not only inefficient and uncompetitive, but it completely fails to take into account differences in productivity across sectors. This limits the ability of firms to create formal jobs and constrains the movement of workers from low to high-productivity activities. Reducing labor costs and making regulations more flexible would help firms to increase their competitiveness in the long run.

Ecuador needs to completely reform the structure of its minimum wage and its mechanism for setting it. The process must be simplified and must relate more closely to changes in the average productivity per worker. An initial reform could be to modify the inefficient structure of wages by sector and occupation to a structure that considers workers' skill levels. Other possible reforms include: 
Reinstating hourly contracts, at least for young workers, thereby giving firms flexibility to generate formal jobs. The primary challenge with this reform is learning from the past and having clear rules that protect workers when implementing this type of contracts. Constitution reforms are needed and will not be implemented in the short term. Hourly contracts could also generate opposition from social sectors.

Reducing the cost of dismissal for firms. A first step should be excluding from severance payment workers that resign voluntarily to their jobs.

Making profit sharing non-mandatory. The rules of profit sharing should be optional rather than obligatory, thus incentivizing workers to increase their performance Also, new firms should be exempted during their first year of operation.

Redesigning the structure of unemployment insurance. The application process should be simplified and access should be opened up to independent workers on similar terms as for formal workers. 


\subsection{An Analysis of Minimum Price Supports in Ecuador}

\section{a. Agricultural Incentives in Ecuador}

Ecuador's system of agricultural incentives is currently under debate, with particular focus falling on minimum price support (MPS) and import quotas. Anecdotal evidence suggests that MPS limits the competitiveness of high-value exportable commodities and of certain agroindustrial value chains - the burden of which is transferred to local consumers. To date, little evidence exists as to how a reform of agricultural policies would impact Ecuador's farmers, especially smallholders who are heavily dependent on the current incentive system. When considering potential shifts in the support provided to producers, it is important to prioritize how public resources can best help improve the competitiveness of agriculture and promote the commercialization of those crops where Ecuador enjoys a comparative advantage. Additional considerations include how subsidies can best serve poor rural producers and how producers can remain informed about changes arising from policy shifts.

\section{Ecuador is part of the Andean Community of Nations and adheres to a system of price bands} in agriculture for specific products. The country applies variable import duties ad valorem when reference prices for those products at international level are below certain floor levels. Similarly, it applies tariff reductions to reduce import costs when international prices rise above a certain ceiling. These price floors and ceilings are set by the Andean Community of Nations. At the same time, the Ecuadorian government defines minimum support prices for specific products (maize, rice, banana, soy, milk, barley and wheat) at a domestic level. As part of this process, it considers price volatility in international markets, lack of storage capacity of producers, and the market power of intermediaries. Support prices are set annually by the Ministry of Agriculture and Livestock (Ministry of Agriculture, hitherto). Although benchmarking with other countries in the region suggests that Ecuador's support for its producers is average in absolute terms, governmentbacked incentive measures have risen dramatically since 2013 (Figure 41). By 2016, for example, they averaged nearly 12 percent of total gross income for agriculture. Over 90 percent of all support to individual producers came in the form of MPS as opposed to direct support. 
Figure 41. Estimated Producer Support (EAP) in Ecuador, 2006-2016

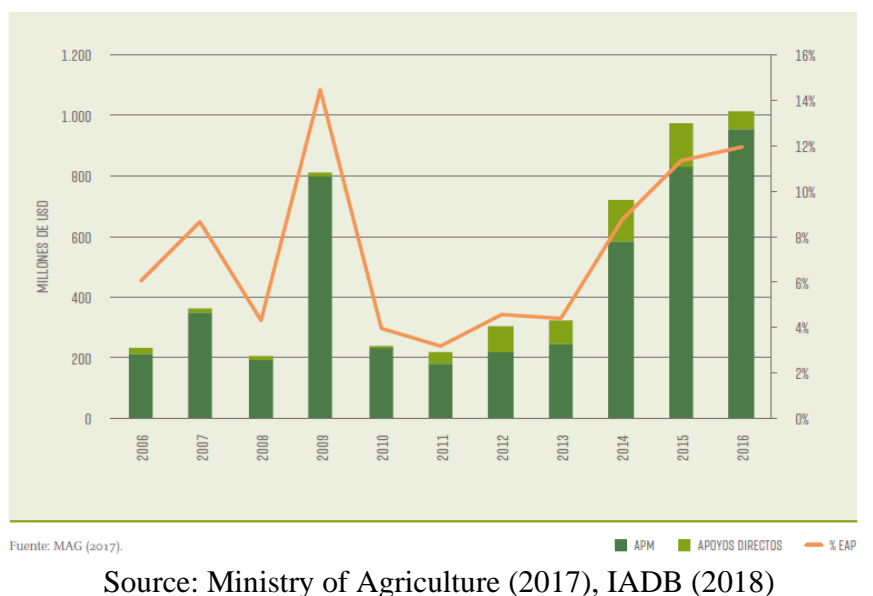

By guaranteeing above-market prices, MPS typically promotes overproduction, requiring governments to purchase and store the oversupply, which effectively acts as a tax on consumers and intermediary purchasers. Contrary to expectations, it is neither the poorest nor the richest households that benefit from this type of policy. According to micro-level research (Deaton 1989), those on middle incomes stand to benefit most since the highest number of net sellers of targeted agricultural products tend to be concentrated in this economic segment. In contrast, the poorest households tend to be adversely affected by these policies because the vast majority of these households produce less than their own needs. Therefore, a direct effect of higher price policies is a deterioration in the real income of poor households (Deaton 1989).

The following analysis presents trends and other dynamics around MPS for the three food groups most affected by the policy - rice, maize, and milk - and subsequently assesses the distributional impacts on producers and consumers. The analysis explores different strategies adopted for each of these three food groups with regards to MPS and asks how the policy has impacted production and sales for farmers. Meanwhile, the descriptive analysis compares the pattern of production and sales for low value-added products (such as rice and maize) that are benefitting from MPS and high value-added products (such as bananas) that receive no significant government support. The analysis takes 2014, just before policy shifts were introduced, as its starting point due to the themes under investigation and the methodological issues in question. Time-series analyses were carried out using agricultural survey data from INEC and the Ministry of Agriculture (see Annex 1 for data sources). The distributional analysis, meanwhile, depends on data from the most recent budget survey (2011) and labor force survey (from 2016) that are available. This permits a calculation of the estimated direct effect of prices changes on households as producers and consumers of these goods. Furthermore, using the desegregated input-output matrix, an estimation of the indirect effect on household welfare arising from the impacts on prices 
for other consumptions good and services was undertaken. Finally, we estimated how changes in maize prices affects expenditure on animal feeding. The distributive impact analysis focuses on 2016 as this was the year in which the level of support was not only highest for all the products that can be analyzed using the ENIGHUR database, but also the most positive and significant.

\section{b. Characteristics of Households Active in the Agricultural Sector}

Among the agricultural households that are at a higher risk of poverty, 65 percent of households falling into the bottom four deciles of the expenditure distribution (compared with 32 percent of households active in other sectors). Average monthly expenditure per capita is $\$ 157.50$ in the case of households operating in the agricultural sector, compared with the $\$ 279.80$ spent by members of households active in other sectors. A larger share of households engaged in agriculture are indigenous and significantly less educated.

The distribution of producer and production characteristics for food groups analyzed in the study reveals some clear differences, with rice producers in particular characterized by high levels of inequality. Large-scale rice producers are responsible for 54 percent of total rice production. They are characterized by higher levels of education (12 percent have tertiary education, compared to just 1 percent of other farmers) and better economic conditions (40 percent belong to the top three income deciles, compared to 15 percent of others). An overwhelming share of rice producers (96 percent) are located in the Costa region; in the case of large-scale rice producers, this proportion rises to 99 percent. Large-scale farmers produce on average 105 metric tons of rice, compared to 7.8 metric tons (by value) in the case of medium-sized producers. Similar significant differences are evident in the quantity of rice sold. In rural areas, most households produce rice; 86 percent in the case of large producers and 91 percent in the case of medium producers. Large producers are concentrated in the Costa region, whereas micro producers are principally operating in the Sierra region.

In the case of maize producers, farm size correlates less strongly with inequality between producers. Notably, available data do not show any link between the level of education of the head of household and land ownership. Large-scale producers are responsible for 56 percent of total maize production. This compares to 26 percent for medium-sized producers, and 6 percent and 12 percent for micro and small-scale producers, respectively. Moreover, in stark contrast to the trend in rice production, large-scale maize producers tend to be less educated than other producers. One consistent finding across all three food groups, however, is that larger producers have a higher level of wellbeing. About 30 percent of large-scale producers belong to deciles 7 to 10 , for instance, compared to only 10 percent in the case of micro producers. More than half (55 percent) of all micro and small-scale maize producers can be found in the Costa region, with a further 33 percent in the Sierra. In contrast, 85 percent and 82 percent of medium-sized and largescale producers are located in the Costa, respectively. No linear relationship can be observed between land size and production levels. The average quantity of maize produced by micro 
producers equals 0.2 metric tons. This compares to 1.2 metric tons for small-scale farmers, 4.1 metric tons for medium-sized producers, and 35.2 metric tons for large-scale farmers.

While a clearer trend can be observed regarding the geographic location of milk producers, as a group they are mostly very poor and show little demarcation according to size. The production of milk is concentrated in Sierra region, which is home to 75 percent of all producers. Among micro producers, 64.5 percent are found in the Sierra region. The figure is more concentrated in the case of large-scale producers, at 86.9 percent. One stand-out feature about Ecuador's milk producers is their homogeneity across producer sizes. The percentage of producers with no education or with only primary education stands at 90 percent for micro producers; the

figure for large-scale producers is ten percentage points lower. The difference grows in respect of consumption. One third of large-scale producers occupy deciles 7-10 of consumption, for example, compared to a mere 13 percent of micro producers. Average production levels demonstrate no linear relationship with producer size. Micro producers average 0.2 metric tons of milk per year, for instance, compared to 1.8 metric tons for medium-sized producers. For large-scale producers, meanwhile, production levels leap to 11.1 metric tons.

\section{c. The Evolution of MPS and Import-Export Patterns for Competitiveness}

In 2014, the government changed its MPS policy, with the result that support for producers increased significantly and the indirect benefits previously enjoyed by consumers decreased - albeit with important differences across food groups. Estimates from the Ministry of Agriculture show the evolution of the reference prices at international level and the prices paid to producers. When the difference is negative, it implies consumers are benefitting from governmental decisions; a positive difference, in contrast, indicates that farmers are receiving support that exceeds the equilibrium market price (Figure 42). Obviously, both strategies tend to generate distortions within the market. In the case of rice, for example, support for producers has increased constantly in recent years, rising from \$33.9 per ton in 2013 to $\$ 153$ per ton in 2016. Similarly, the MPS for milk producers started becoming significant in 2016. State aid for maize producers, on the other hand, has remained more or less stable since 2014 (at around \$100 per ton). As for bananas, MSP could be considered neutral since 2013.

Figure 42. Variation in the Difference between Producer Prices and Reference Prices at Farm Level, Ecuador 2011-2016 


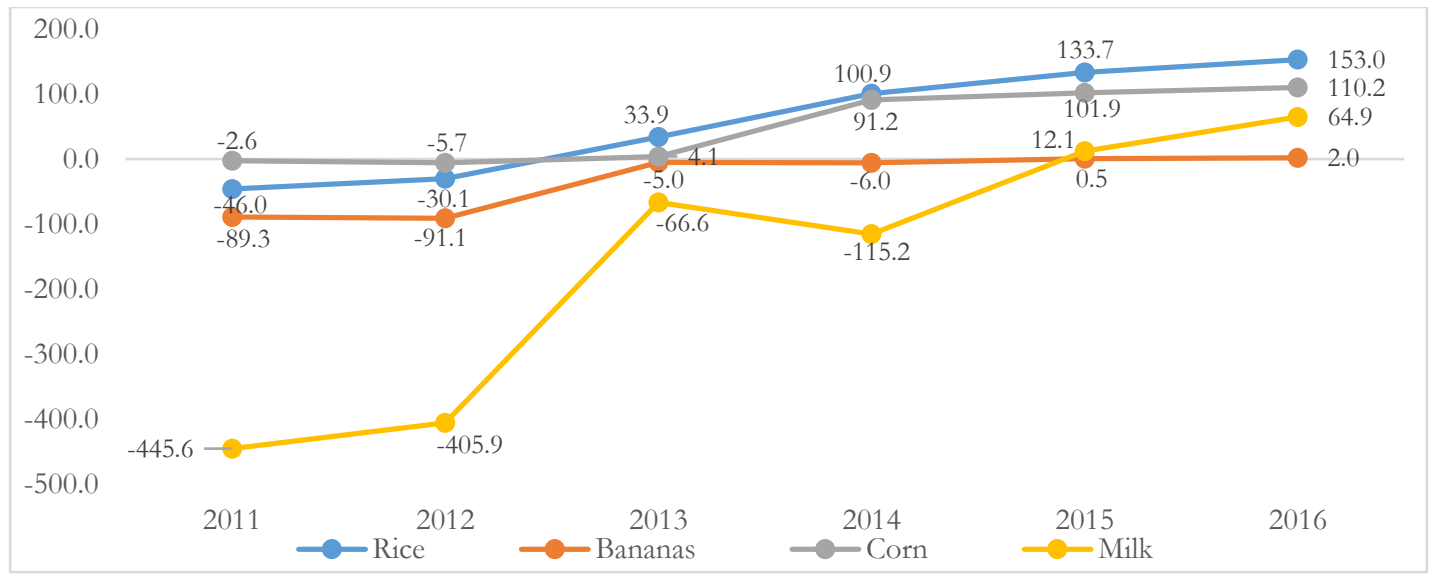

Source: Data elaborated with the Ministry of Agriculture, 2019

Government aid for producers via MSP has steadily risen since 2011, especially for milk. In all cases, the value of support increased significantly since the government's MSP policy shifted from being a consumer-focused support to a producer-oriented support, as shown in Figure 43. The value of government aid represents the difference between the producer price and reference price. This is calculated from 2011 (when government policy changed) to 2016 (the most recent year for which data are available). The year 2011 also serves as a baseline reference because it precedes the initial year (i.e. 2012) for which production and sales' figures are collected for this analysis. Evolution of aid for bananas producers is exempted from this calculation given the neutral nature of the aid provided.

Figure 43. Rise of MPS for producers. 2011 = reference value, Ecuador 2011-2016

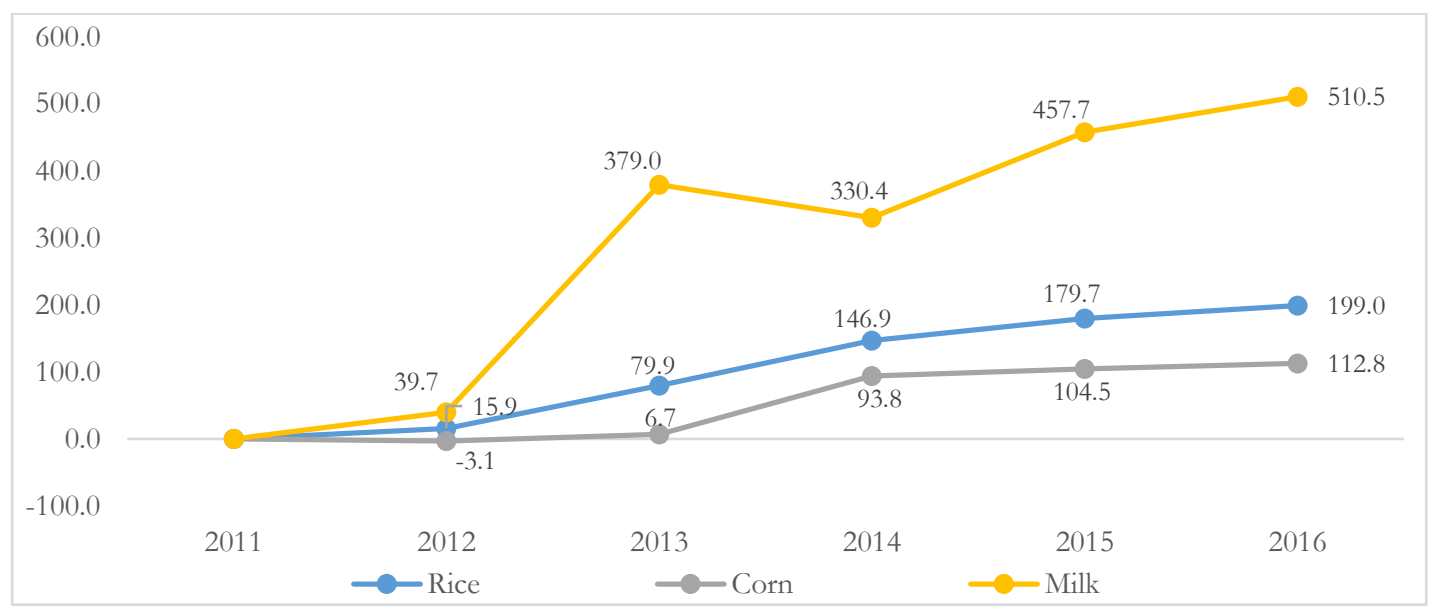

Source: Data elaborated with the Ministry of Agriculture 2019

Another type of support directed towards producers are direct transfers, the value of which has increased for rice and maize farmers since $\mathbf{2 0 1 4}$ and for milk farmers since $\mathbf{2 0 1 6}$ (Figure 44). As with MPS, the level of aid directed towards banana production seems to be more neutral. 
Ecuador is a net importer of maize, while it is a net exporter of rice, milk, and, in particular, bananas. As a consequence, farmers typically favor banana production because of the sizeable export opportunities that it presents; the comparatively smaller markets for rice, milk, and particularly maize mean these food groups are seen as less profitable and therefore less attractive to producers.

\section{Figure 44. Producer direct transfers for specific commodities, 2011-2016. Total \$ million.}

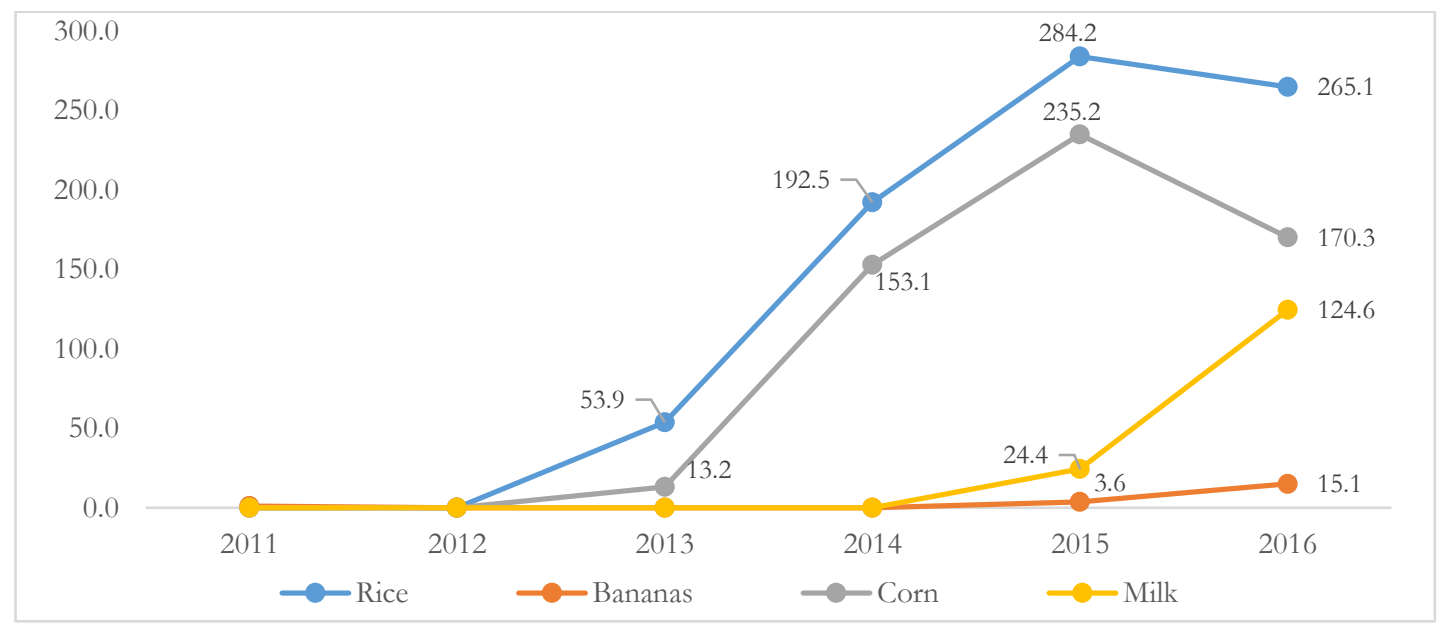

Source: Data elaborated with the Ministry of Agriculture 2019

Exports of rice, corn, and maize have contracted significantly over recent years (Figure 45), despite a relatively stable level of domestic production. This phenomenon is seemingly related to the government's decision to distort the market by increasing the "internal" support for producers who were selling their products using resources stemming from the government and from indirect taxes on Ecuadorian consumers (rather than relying on the external market). The opposite tendency can be seen with banana producers, who received neutral aid from the government and whose export volumes increased continually and significantly during the same time period. ${ }^{47}$ The overall impact on trade balance associated with these policies also merits attention. As the following graphs illustrate, increases in public aid correlate with a fall in import volumes (Figures 45 and 46). One possible explanation for this is that the relative importance of product imports decreases in line with a rise of direct purchase of products. Another explanation is that an increase in MSP reduces the domestic demand for imported products. This is evident in the case of rice, for instance. Imports of this staple commodity dropped in 2013 and 2014 just when direct transfers and price support increased. For maize, meanwhile, the years 2015 and 2016 witnessed a reduction in direct transfers. Over this same period, imports increased. This marked a departure from the trend over previous years, during which maize imports were consistently decreasing. Ecuador does not import milk, hence its absence from this particular analysis.

\footnotetext{
${ }^{47}$ The data available for this study point to a correlation between export levels and producers' receipt of price support and direct transfers; they are agnostic as to whether a causal relationship exists between the two.
} 
Figure 45. Net weight exported in kg of specific products, Ecuador 2011-2016.

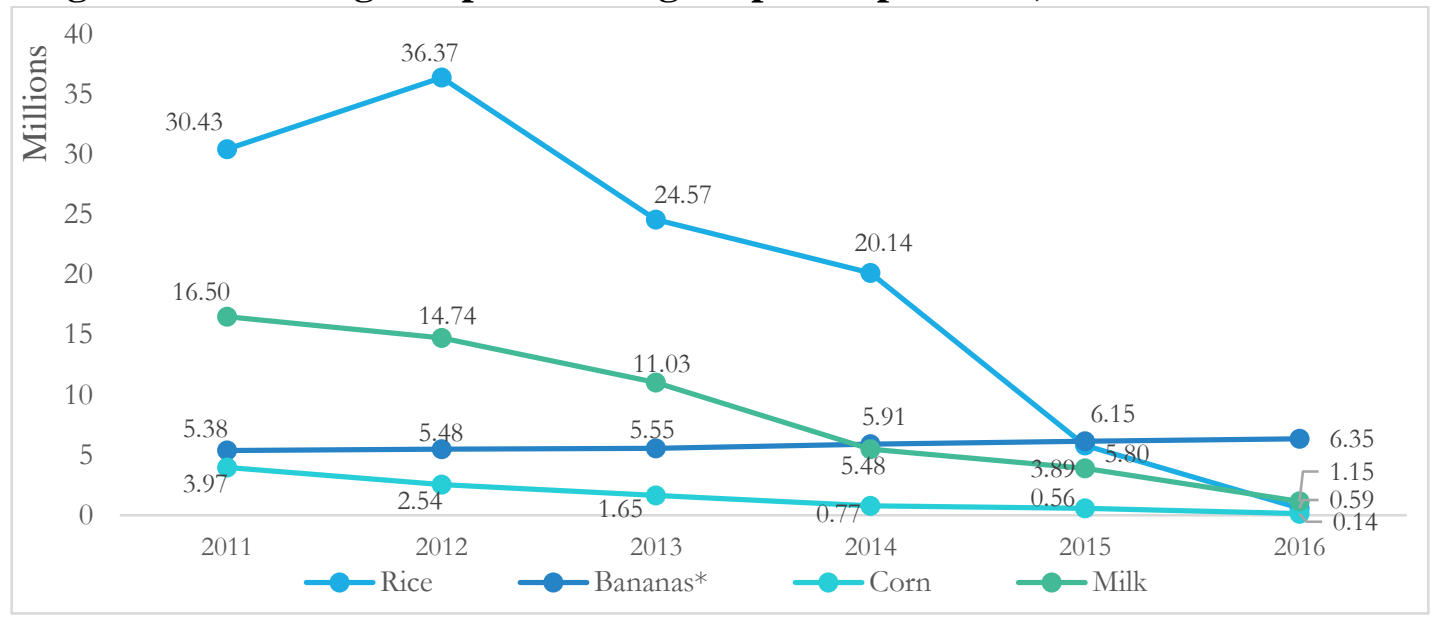

Three-year moving average *Bananas: data divided by 1,000

Source: Data elaborated with UN COMTRADE

Figure 46. Net weight imported in kg of specific products, Ecuador 2011-2016.

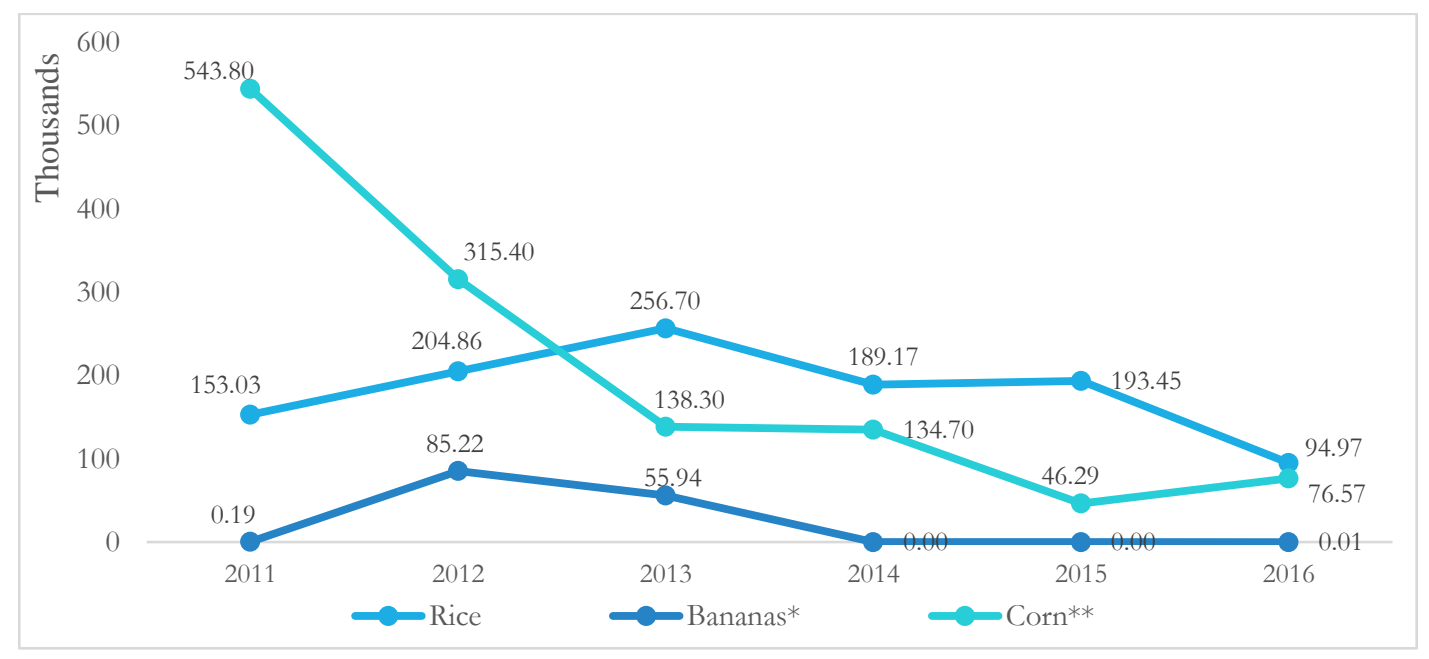

*Bananas: data divided by $100 * *$ Corn: data divided by 1,000

Source: Data elaborated with UN COMTRADE

Research indicates that the removal of MSP and similar incentive programs reduce the competitiveness of small producers and prompt them to withdraw from the market - an outcome already evident in Ecuador. The overall number of farms in the country has decreased consistently in recent years, from 3.34 million in 2014 to 2.67 million by the latest count (Table 14). This decline extends to family-owned farms, as it does to those owned and managed by micro and small-scale producers. Of the 670,000 or so farms that have ceased operations in recent years, the vast majority belong to small farmers of one kind or another. The story is different for larger producers. Indeed, since 2014, the number of medium-sized and large-scale farms in Ecuador has increased by 5.5 percent (up from 614,865 , to 648,099 ). An examination of production and sales' 
volumes by farm-size strata demonstrates a contrasting picture. As shown in Table 14, family farming marked a notable increase in both production and sales, from 3.33 million tons in 2014 to 3.87 million tons in 2016. A similar upward trend can be seen for micro, small, and - especially medium-sized producers. For this last group, increases averaged around 40 percent for production and 45 percent for sales. For large-scale producers, however, 2016 signaled a fall in production and sales. This came after three successive years of gradual growth.

Table 14. Total number of farms and agricultural production by type of farmers, Ecuador 2012-2016

\begin{tabular}{|c|c|c|c|c|c|}
\hline FARMS (\#) & 2012 & 2013 & 2014 & 2015 & 2016 \\
\hline Family farming & $1,350,671$ & $1,179,622$ & $2,346,656$ & $2,417,405$ & $1,874,282$ \\
\hline Micro size & $1,180,762$ & 969,924 & $2,292,613$ & $2,192,296$ & $1,635,976$ \\
\hline Small size & 381,741 & 369,048 & 439,968 & 414,384 & 391,264 \\
\hline Medium size & 304,154 & 297,872 & 346,351 & 377,692 & 373,556 \\
\hline Large size & 202,415 & 212,962 & 268,514 & 292,598 & 274,543 \\
\hline All the farmers & $2,069,072$ & $1,849,806$ & $3,347,446$ & $3,276,970$ & $2,675,339$ \\
\hline $\begin{array}{c}\text { PRODUCTION } \\
\text { (tons) }\end{array}$ & 2012 & 2013 & 2014 & 2015 & 2016 \\
\hline Family farming & $3,829,173$ & $3,663,853$ & $3,338,000$ & $4,148,981$ & $3,875,911$ \\
\hline Micro size & 531,057 & 465,047 & 884,719 & $1,045,536$ & 931,866 \\
\hline Small size & 651,777 & 617,021 & 805,005 & 978,613 & 942,936 \\
\hline Medium size & $1,493,614$ & $1,425,072$ & $1,582,148$ & $2,202,722$ & $2,226,517$ \\
\hline Large size & $19,509,161$ & $17,855,557$ & $20,994,859$ & $23,857,450$ & $19,453,508$ \\
\hline All the farmers & $22,179,651$ & $20,356,124$ & $24,260,966$ & $28,079,089$ & $23,549,241$ \\
\hline $\begin{array}{c}\text { SALES } \\
\text { (tons) }\end{array}$ & 2012 & 2013 & 2014 & 2015 & 2016 \\
\hline Family farming & $3,411,712$ & $3,353,577$ & $2,954,747$ & $3,797,506$ & $3,567,136$ \\
\hline Micro size & 353,428 & 331,574 & 673,540 & 789,990 & 743,217 \\
\hline Small size & 533,631 & 515,047 & 659,432 & 883,145 & 848,570 \\
\hline Medium size & $1,358,144$ & $1,309,526$ & $1,470,338$ & $2,071,980$ & $2,133,577$ \\
\hline Large size & $19,001,613$ & $17,498,566$ & $20,752,606$ & $23,257,411$ & $19,229,067$ \\
\hline All the farmers & $21,251,049$ & $19,659,474$ & $23,559,798$ & $27,006,280$ & $22,958,484$ \\
\hline
\end{tabular}

Source: Data elaborated using ESPAC Ecuador 
Although six out of ten (50 percent) of Ecuador's farms are micro-sized, food production for these farms represents less than 4 percent of the country's total agricultural output. In contrast, large producers generate more than 80 percent of Ecuador's overall agricultural production despite comprising no more than 10 percent of the country's total number of farmers. Similar percentages can be observed in respect of sales.

A clear relationship exists between the level of producer support and production patterns, particularly for family farmers, with production increasing for food groups with higher support (like rice) and decreasing for those without such support (such as bananas). In the case of the latter, this decrease occurs despite the fact that these food groups area high-value and export-oriented. As for rice, production levels increased along with levels of producer support. In 2014 , at the time when producer support first began to rise, rice production amount to around 5.7 percent of total agricultural production in Ecuador. By 2016, it had risen to a 6.5-percent share. Maize production, in contrast, fluctuated between moments of growth (in 2015, production stood at 6.7 percent of total production) and contraction (by 2016, its share of total production had fallen back to 4.7 percent). Interestingly, for family farmers, the effects of changes in MPS are shown to be identical but stronger during the 2014-2016 period. Aligned with MPS, a stable trend can be observed in banana production across all groups. That said, the data reveal that family farmers reduced their production of this high value-added crop, opting instead for crops such as rice that had a higher MPS. This suggests that producer supports can have particularly distortionary effects among smaller farmers, with such supports overriding the comparative advantages that high-value, export-oriented crops otherwise enjoy. In the case of milk, producer support only became significant from 2016 onwards and thus no clear trends are observed within the time frame of this analysis.

An analysis of the production-to-sales ratio for the four focus food groups reveals zero surplus for maize, rice, and bananas, but a 30-percent surplus for milk. An increase in market participation (quantity sold) of micro and small producers is observed in the case of rice. Nevertheless, due to the reduced amount of production among these groups, the overall increase in sales is driven by large and medium-sized producers. As far as milk is concerned, it is primarily large-scale farmers that are stimulating the rise in sales. For rice, maize, and - especially - bananas, the probability of market participation goes up with farm size. For milk, in contrast, levels of market participation are similar or lower, independent of the farm size. This implies that a large amount of milk production is used for non-sale purposes, such as auto-consumption or downstream production.

Table 15. Share of total production for specific products. Ecuador 2012-2016.

\begin{tabular}{cccc|ccc}
\hline All the farmer & Farm size & $\mathbf{2 0 1 2}$ & $\mathbf{2 0 1 3}$ & $\mathbf{2 0 1 4}$ & $\mathbf{2 0 1 5}$ & $\mathbf{2 0 1 6}$ \\
\hline \multirow{2}{*}{ Maize } & Micro & 4.5 & 4.1 & 5.6 & 5.9 & 6.0 \\
& Small & 7.9 & 7.6 & 9.0 & 11.1 & 12.1
\end{tabular}




\begin{tabular}{|c|c|c|c|c|c|c|}
\hline & Medium & 21.7 & 25.1 & 24.4 & 27.1 & 26.1 \\
\hline & Large & 65.8 & 63.2 & 60.9 & 55.8 & 55.8 \\
\hline & Total & 100.0 & 100.0 & 100.0 & 100.0 & 100.0 \\
\hline \multirow{5}{*}{ Rice } & Micro & 4.2 & 2.9 & 3.7 & 7.2 & 9.5 \\
\hline & Small & 6.5 & 5.9 & 6.6 & 10.3 & 11.1 \\
\hline & Medium & 18.0 & 16.5 & 20.6 & 22.2 & 25.1 \\
\hline & Large & 71.2 & 74.7 & 69.1 & 60.3 & 54.4 \\
\hline & Total & 100.0 & 100.0 & 100.0 & 100.0 & 100.0 \\
\hline \multirow{5}{*}{ Milk } & Micro & 2.7 & 3.2 & 3.0 & 2.8 & 2.9 \\
\hline & Small & 8.7 & 8.6 & 11.0 & 6.2 & 6.0 \\
\hline & Medium & 16.0 & 15.5 & 16.6 & 16.2 & 16.9 \\
\hline & Large & 72.7 & 72.7 & 69.4 & 74.9 & 74.2 \\
\hline & Total & 100.0 & 100.0 & 100.0 & 100.0 & 100.0 \\
\hline \multirow{5}{*}{ Bananas } & Micro & 0.6 & 0.8 & 0.3 & 1.0 & 0.5 \\
\hline & Small & 1.2 & 1.1 & 0.9 & 0.9 & 1.1 \\
\hline & Medium & 3.4 & 4.9 & 1.2 & 2.5 & 2.5 \\
\hline & Large & 94.7 & 93.2 & 97.6 & 95.7 & 96.0 \\
\hline & Total & 100.0 & 100.0 & 100.0 & 100.0 & 100.0 \\
\hline
\end{tabular}

Source: Data elaborated using ESPAC Ecuador

Focusing on farm size as the primary unit of analysis, maize and rice are shown to experience a significant decrease in their share of production stemming from large-sized producers (Table 15). Since 2014, the amount of maize produced by large-scale farmers has decreased from 60.9 percent to 55.8 percent. For rice, the decline is even more marked, falling from 69.1 percent to 54.4 percent over the same period. The gap was partly filled by small and medium-sized farmers, who augmented their respective share in the market although at a lower rate. It can be surmised, therefore, that the constant rise in market share is due to public support for these crops and the ensuing incentive for smaller farmers to increase production. For milk and banana production, meanwhile, the trend is different. Production by large-scale farmers is shown to have either risen or remained stable. Sales' volumes show an identical trend for the most part, influenced as they are by the same drivers as production. Rice sales by micro and small-scale producers represent an exception, however, with sales' volumes growing faster than increases in production. In 2016, micro farmers sold 291 percent more rice than in 2014. This compares with an increase of production of 187 percent over the same period. For small-scale farmers, the respective increases 
in production and sales' volumes was 120 percent and 87 percent. This can be explained by the strong growth of the MPS for rice, which benefitted these smaller farmers in particular.

\section{d. An Analysis of the Distributive Welfare Effects of MPS}

\section{The direct production effects of the MPS for rice, maize, and milk are pro-poor and stand for a significant share of the income for the lowest deciles. Although the MPS is horizontal and} affects all producers, it constitutes a significantly larger relative share of poor producers' incomes. That said, in absolute terms (i.e. amount of dollars actually received), larger-scale producers actually benefit more. For this analysis, the estimated support to "producer households" captured through the household survey represents only part of the Ministry of Agriculture's overall support. In the case of rice and milk, for example, the value of support for all households is 58 percent of the official estimate. In the case of corn, it is only 28 percent. These results suggest that commercial farms or other economic agents could be receiving a significant share of government support. Even so, it can be assumed that current estimates accurately capture the distributive impacts of MPS on small-scale, informal producers. Of note here is the fact that the concentration curves are above the Perfect Equity Line (see methodology below). This indicates that the households of lowincome, informal producers receive a larger share of support than average. For instance, the bottom 40 percent of producers benefit from about two-thirds of the support that the government gives for milk and maize production. In the case of rice, informal household farmers receive 80 percent of all government support (Figure 47, panel A). For higher-income farmers, receiving 50 percent of the production support is practically insignificant; for the most deprived 10 percent, on the other hand, it represents almost 15 percent of their total income (Figure below, panel B). Rice is the main contributor to this effect (64 percent), followed by maize (21 percent). Removing the MPS for rice could generate a reduction of 0.4 percentage points in the poverty rate. The potential reduction in the case of maize and milk is 0.07 percentage points and 0.19 percentage points, respectively.

\section{Methodology: Distributional Impact Analysis}

Worldwide, governments affect economic agents through fiscal policy and regulation, among other measures. These actions tend to have a different impact on households, including farm producers. Therefore, public policy could be non-neutral from a distributional perspective. Distributional impact analysis shows how policy actions affect households through distributional impacts on welfare. This analysis aims to assess the effectiveness of MPS in impacting its target recipients and the effects it has on household welfare. A typical distributional analysis brings two main results. First, it assesses the targeting of the policy action, revealing the benefits to lower strata households as a share of the total benefits. Second, it estimates the distributional impact by comparing the observed distribution with a contrafactual distribution. The key point is to have the welfare distribution with and without the policy action.

In addition, it is possible to ascertain if the policy action is pro-poor (i.e. if benefits are higher for households in lower-welfare strata). The concentration curve of benefits $\left(L_{B}\right)$ illustrates this point. The $L_{B}$ curve shows the cumulative share of benefits through the cumulative shares of households in a $1 \mathrm{x} 1$ box. If benefits are distributed 
with perfect equality, the $L_{B}$ curve will mirror the 45 -degree line from the $(0 ; 0)$ to the $(1 ; 1)$ points, which is the Perfect Equity Line (PEL). The policy action will be pro-poor if the $L_{B}$ curve is concave (i.e. if it is above the PEL).

(1) $L_{B}(p)=\int_{0}^{y} \frac{B(x) f(x) d X}{\mu_{B}} ; \quad p=F(y)$, where $B(x)$ is the average benefits for a household with welfare $X$; $f(x)$ is the welfare density function and $\mu_{B}$ is the average benefits for the whole welfare distribution.

The distributional impact of fiscal policy has been widely studied in developing countries. There are several studies for Latin America (e.g. Lusting 2017). Nonetheless, in the past, attention has typically focused on tax and social spending systems. However, some countries included benefits to the agriculture sector. For instance, studies for Ghana (Younger et al. 2015), Uganda (Jellema et al. 2016) and Tanzania (Younger et al. 2016) assess the distributional impact of subsidized inputs for agriculture. In Ethiopia, Hill et al. (2017) studied the impact of the country's food security and rural safety net program.

Figure 47. Production effect of MPS by product.

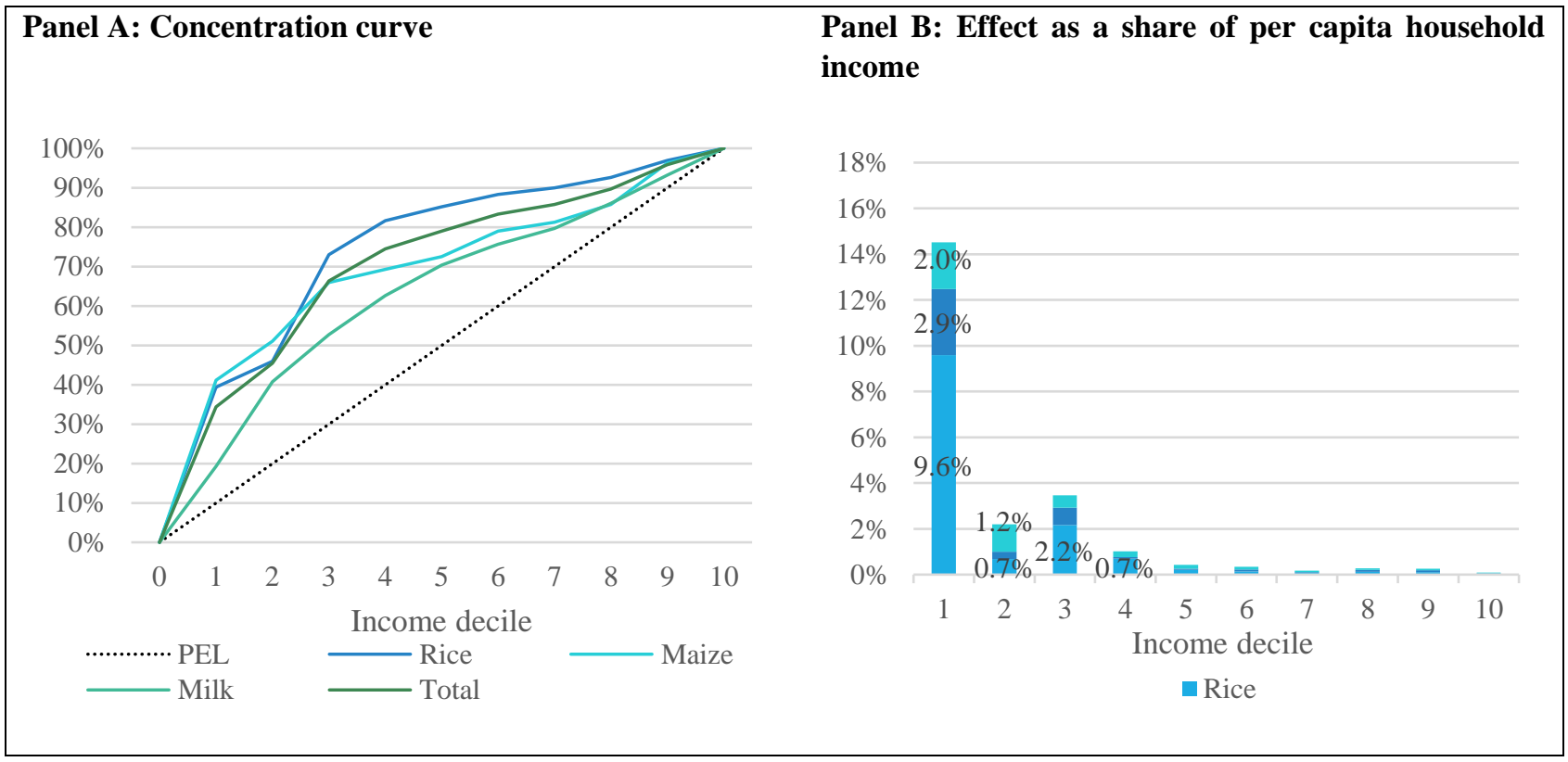

Source: Authors' elaboration based on INEC, ENIGHUR (2011), and ENEMDU (2016)

Direct effects on consumers are practically negligible and therefore do not generate welfare impacts, implicit taxes, or subsidies for consumers, despite being pro-poor. In the case of maize, rice and milk, the direct effect through consumption represents less than 0.11 percent of income (Figure 48, panel B). This can be explained by the fact that households typically consume farmers' products after they have undergone some form of processing or transformation, rather than consuming them directly. In the case of rice, impacts are zero in the whole income distribution. Milk is the main explanatory factor for all deciles, especially for the middle segments (Figure 7, panel B). The only instance where this is not true is for the poorest decile. For deciles 3 to 7 , milk represents more than 70 percent of the total direct consumption effect. For the first decile, maize explains two-thirds of the effect. However, these effects on the share of per capita household income are negligible. Note that the effect through consumption works like that of a 
negative tax (subsidy). Thus, the concentration curve interpretation is opposite to the case of the income (production) channel. Thus, these effects are pro-poor since they are concentrated mainly in the highest deciles and the concentration of benefits curves are below the PEL (Figure 48, panel A). By way of illustration, the wealthiest 40 percent supports more than half the effect for rice, maize and milk.

Figure 48. Direct effect of MPS on consumption by product.

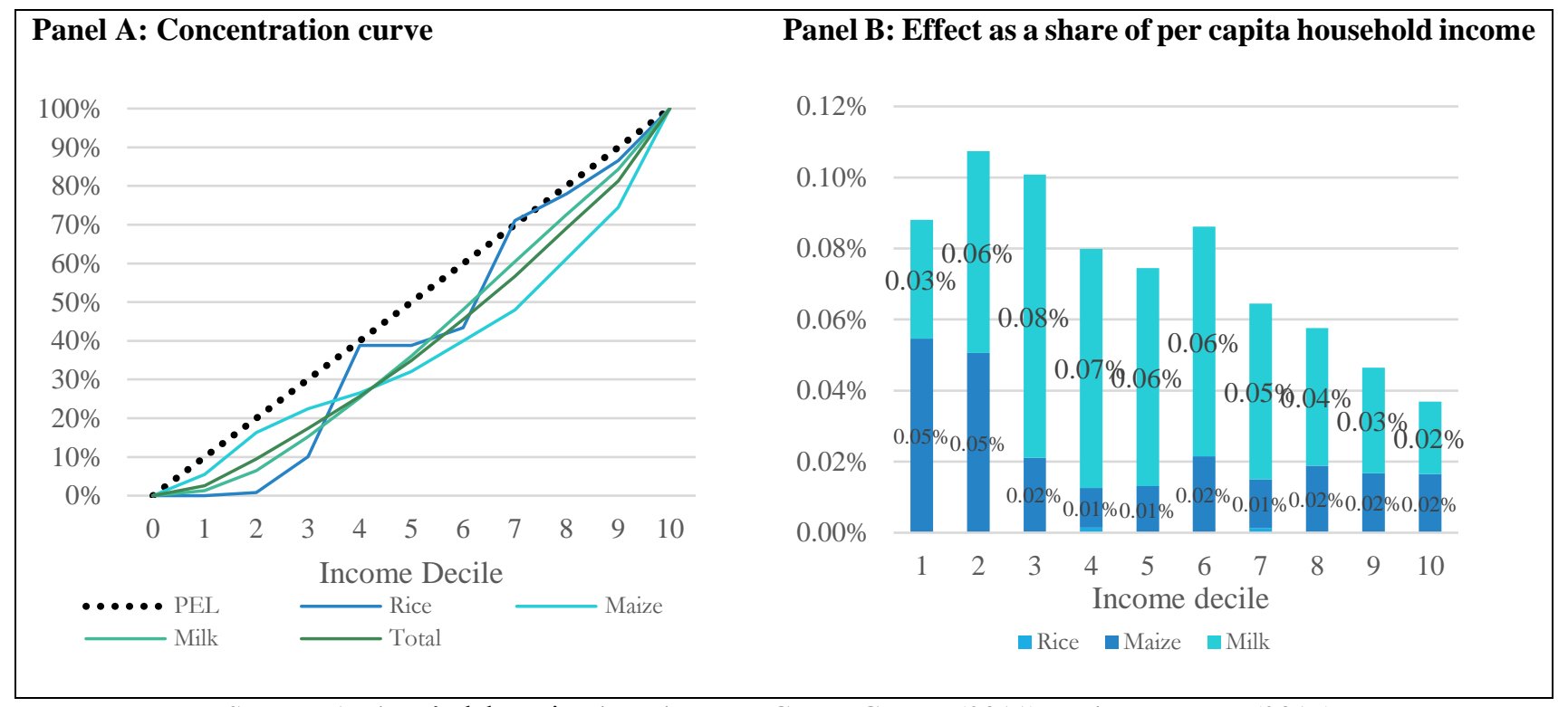

Source: Authors' elaboration based on INEC, ENIGHUR (2011), and ENEMDU (2016).

The effects of indirect consumption act as a subsidy to consumers for milk and maize, but as a tax on consumers for rice. The concentration curves for maize and milk are below the PEL, implying that higher deciles support a larger share of the effect. For both products, the richest 40 percent contributes about half the effect (Figure 49, panel A). However, in the case of rice, the concentration curve is above the PEL. In this instance, the poorest 40 percent supports 55 percent of the effect.

Nonetheless, the effects of indirect consumption (such as an implicit tax) are high for lowerincome households, particularly through the MPS on rice; consequently, removal of the MPS could lead to an estimated $\mathbf{0 . 6 8}$ percentage point reduction in the poverty rate. For the bottom 40 percent, the indirect effect of all products exceeds 1.5 percent of per capita household income, reaching 3.7 percent for the second decile and almost 7 percent for the most deprived 10 percent (Figure 49, panel A). For the lowest deciles, rice is the primary driver of the total effect. For instance, it represents two-thirds of the total effect for households in the first two deciles (Figure 49, panel B). On the other hand, the effect of milk is more important for the highest deciles, representing half of the total effect for the wealthiest 20 percent (Figure 49, panel B). The additional amount that households pay for these products could be considered as a loss of income. In this way, the potential equivalent change in poverty can be evaluated. Removing the MPS for 
rice would be equivalent to a reduction of 0.68 percentage points in the poverty rate. For maize and milk, the respective reduction would be 0.1 percentage points and 0.33 percentage points. These values more than offset the expected positive production effect for informal household producers discussed above. However, for the lowest decile of informal producers, the effects for the income channel (14.5 percent) is more than double that of consumption (6.9 percent). This suggests that an increase in the rate of extreme poverty and the overall poverty gap is a possibility.

\section{Figure 49. Indirect effect of MPS on consumption by product.}

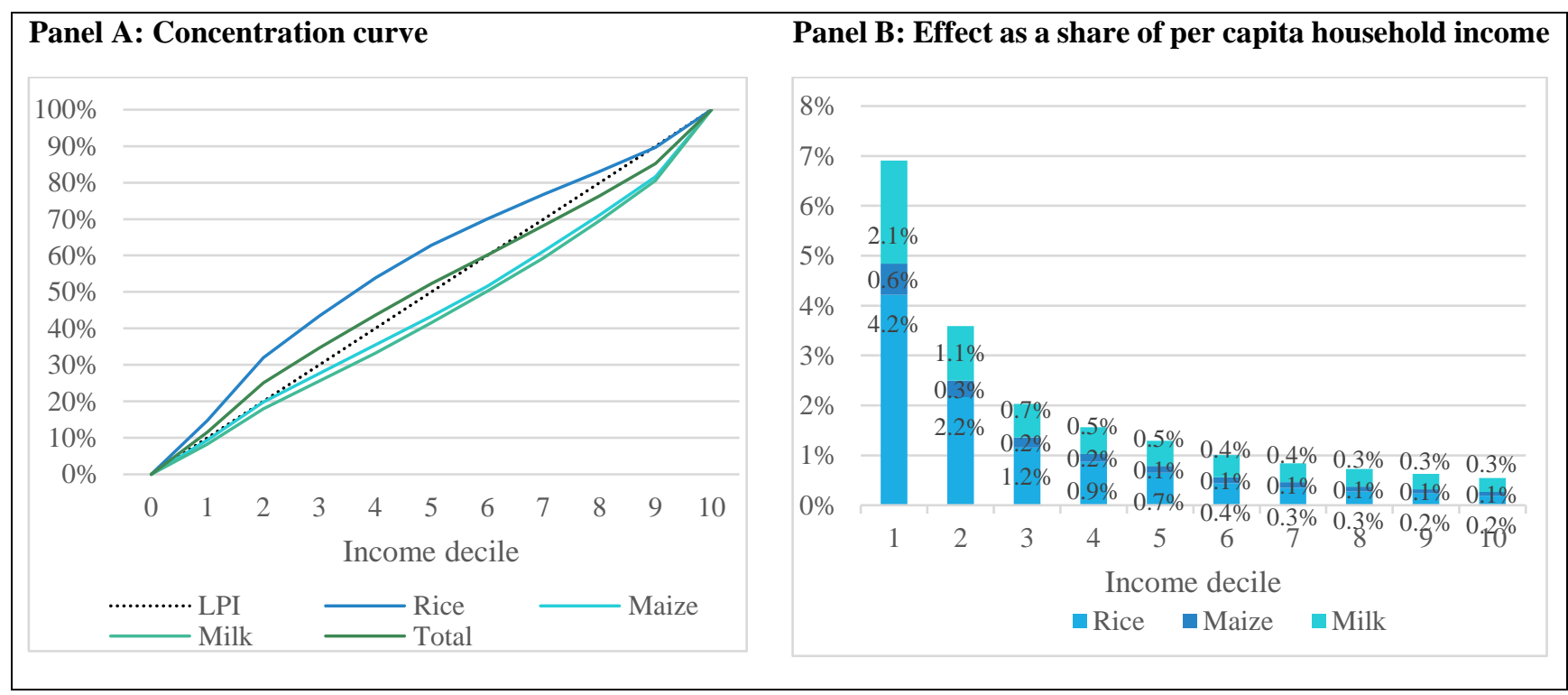

Source: Authors' elaboration based on INEC, ENIGHUR (2011), and ENEMDU (2016).

In general, the distributive welfare analysis suggests that the direct production effects on informal farmers and the indirect consumption effects are higher for lower-strata households. MPS increases informal household producers' income by directly raising household income. Except for the first decile, the distributive analysis results show that the consumption effects, vis-à-vis implicit taxes, are higher than those on the production side. Thus, the MPS policy mainly seems to generate a redistribution from poor households that consume these products (and their derivatives) to those that produce them. Exploring compensation mechanisms or incentives that do not translate into higher prices at the point of sale could protect consumers, while at the same time preserving income support for producers.

\section{e. International Evidence Shifting to "Decoupled" Payments and Conclusions}

Agricultural incentives have historically concentrated on improving the livelihoods of the poorest farmers and on helping to ensure household food security, both in Ecuador and further afield. Such incentives have largely been associated with MPS policies, which typically benefit poor farmers while distorting incentives for wealthier farmers or commercial producers. Producer supports of this form include not only MPS, but also import quotas and tariffs. These all distort markets. Not only do they prevent competitiveness of downstream industries, but they also 
create perverse incentives for farmers to increase production of food groups for which they lack comparative advantage. The outcome of distortionary agricultural subsidies can also negatively impact climate change, as farmers are incentivized to grow crops with little regard for the climate consequences (World Bank, august 2018). ${ }^{48}$

Current farmer support takes multiple forms that may require public budget outlays. These include investments in much needed public goods, such as research and advisory services, public infrastructure, and food safety and standards. Outlays may also be required for subsidies to agricultural producers. Such subsidies vary in nature and include:

- Price supports to keep domestic prices for specific outputs higher than equivalent world market prices. These supports are given either directly through public spending for the public procurement of farm outputs or indirectly through import restrictions and other market barriers that help push producer prices higher. In the case of market barriers, domestic producers receive implicit transfers from consumers through higher prices for agricultural outputs, with no public expenditures.

- Transfers to producers linked to the type of inputs used or agricultural outputs produced. These subsidies include lowered interest rates on agricultural credit or lowered prices of specific inputs (either variable or fixed capital), such as fertilizers, pesticides, seeds, water, and electricity. Producers can also receive direct payments tied to the production of specific outputs.

- Payments to farmers not tied to the outputs produced or inputs used. These are often referred to as decoupled payments.

MPSs are the easiest to implement and have the lowest public budget outlay. However, these supports are highly distortionary as they restrict imports (to raise domestic prices) or exports (to reduce domestic prices). In the latter case, these supports impose a tax or negative subsidy on farmers. Direct payments linked to the inputs used or types of products produced are less distorting than MPS, but nevertheless encourage excess production of the targeted output or excessive use of the targeted input. Decoupled payments are the least distortionary. They also have less impact on farm prices and associated production decisions. These payments are typically based on current or past land area under crop cultivation or on the amount of livestock owned.

Climate Smart Agriculture (CSA) requires more support for sustainable intensification; critical to achieving these outcomes is an enabling environment that provides efficiency-enhancing public goods while reforming policies that distort market prices and associated input use and production decisions. CSA involves adopting agricultural practices that can meet rising global food demand, mitigate agriculture's greenhouse gas emissions, and adapt to inevitable climate change. The key to making agriculture climate-smart is increasing land-use efficiency through higher productivity as this reduces the need for clearing more land for agricultural production. These productivity gains must also be rooted in using inputs such as water and chemicals more efficiently to reduce any negative environmental impacts.

Benchmarking against international experience of eliminating "coupled" payments such as MPS and moving towards "decoupled" payments to farmers, we find several examples of successful promotion of the latter to boost competitiveness of local economies. New Zealand provides a case in point. In the mid-1980s, for example, the New Zealand government started abolishing MPS on wool, beef, sheep meat, and dairy products. It reduced and/or removed tax concessions, land development loans, and subsidies for fertilizers and irrigation, among other

48 As detailed in the Agricultural Global Practice Note "Realigning Agricultural Support to Promote Climate-Smart Agriculture" (2018) 
measures. By 1989, the Producer Support Estimate had consequently decreased to 3 percent (down from 24 percent in 1979). The result was a clear shift from quantity to quality. On the one hand, the number of New Zealand's sheep and beef farms fell by nearly one third (31 percent) over a two-decade period. On the other hand, average carcass weights increased 25 percent. There was also an increase in the size of farmers' herds during this period as well as a rise in dairy production (of 75 percent). By the early 2000s, despite the country's sheep population falling from 70 million animals to 40 million, export revenues from lamb and sheep actually demonstrated an increase. At this time, productivity levels in the agricultural sector were three times higher than the average for all economic sectors as a whole.

New Zealand also developed a horticultural industry almost from scratch. Before the agricultural reforms of the mid-1980s, horticultural production was small and largely familyfocused. At this time, the majority of subsidies were targeted at meat, wool, and dairy products. The reform process shifted this focus. Together with kiwi fruit and wine, the horticultural industry was one of the most significant beneficiaries, as shown in Table 16.

Table 16. Changes in the export of horticultural products and wine before/after the reforms

\begin{tabular}{lcc}
\hline & Pre-reform & Post-reform \\
& $(1983-1984)$ & $(2004-2005)$ \\
\hline Exports of kiwi fruit (US\$) & 42 million & 405 million \\
Exports of all horticultural products (US\$) & 140 million & 827 million \\
Wine (US\$) & $<10$ million & 125 million \\
\hline
\end{tabular}

Source: Statistics New Zealand (1984, 2003, 2004, 2005)

In 1996, New Zealand launched an Integrated Pest Management (IPM) program, which helped the country meet foreign markets demand (EU, Japan, USA, among others) while also leading the horticulture industry towards an effective, environmentally-sensitive, and economically-sound approach to managing pest organisms. The IPM program was implemented together with a shift in calendar schedules of insecticides and fungicides, as well as a change to disaster monitoring systems and forecast weather information programs (Gianessi, 2013). The success of the horticultural industry in New Zealand, based mostly on the IPM strategy, stimulated a range of other programs, such as 'Integrated Fruit Production' (apples), 'Integrated Wine Production', 'SummerGreen' (stone fruits), 'Avogreen' (avocados), and 'KiwiGreen' (Kilgour et al. 2008). Most of these programs incentivized the growth of these product groups by creating and developing the necessary value chains for both their production and export. They also focused on driving up demand in importer countries. This was especially true for kiwifruits. Today, New Zealand is the third largest producers of this fruit, behind Italy and China (Bredeson 2010).

Changes to kiwifruit production required policy shifts and reorganization of labor, land, and capital factors, leading to a boost in New Zealand exports; similar dynamics can be seen with 
apples, stone fruits, and wine, among other fruit-based industries. As the kiwifruit sector illustrates, the development of any horticulture industry requires the acquisition of productive land, the training of workers, and the enhancement of the full value chain. A further requirement is the expansion of export and marketing structures. For such an expansion to be successful, it is necessary to ensure that the timing and goals of relevant bodies are coordinated, that a promotion strategy is put in place, that prices are set, and that relevant export licenses are acquired. Finally, it may prove necessary to relocate the agricultural and agri-business workforce in order to guarantee the availability of adequate labor.

New Zealand's agricultural policy reforms caused 1 percent of farmers to leave agriculture, far lower than the 16 percent initially predicted (Vitalis 2007). In terms of spillover effects, the reforms were expected to alter farm size. This did happen to an extent, with some land becoming consolidated and the size of some holdings increasing (as in the case of dairy production). The reforms also brought environmental benefits, primarily in the shape of reforestation. This was largely due to the removal of land development subsidies, which made it unviable to use some small areas of land. In such cases, farmers often opted to reforest land that was not suited for pastoral agriculture.

The European Union's (EU) Common Agricultural Policy (CAP) was launched in 1962 and was first approved in 1992 (MacSharry reform). The CAP is a partnership between agriculture and society, and between Europe and its farmers (European Commission 2019). In practice, the CAP is linked to: (i) income support, through direct payments to farmers so as to ensure income stability. It also remunerates farmers for environmentally friendly activities and for delivering public goods (which are not normally paid for by the markets). In total, the CAP represents 70.97 percent of total EU support to farmers; (ii) market measures, which help deal with difficult market situations, such as sudden drops in demand or falls in prices. Such measures represent 4.59 percent of total EU support to farmers; and (iii) rural development measures, which aim to address specific needs faced by rural areas both at local and national level. These make up 24.44 percent of total EU support to farmers. Among the EU-10, ${ }^{49}$ stability measures were implemented in 2004 . These took the form of decoupled direct payments and rural development programs.

Reforms to agricultural incentives implemented through the CAP in the EU have helped increase labor productivity and make crops more competitive both regionally and globally. Productivity improvements were achieved by applying better technologies and/or through more efficient management. The latter involved interventions that were either technical, allocative, or related to scale (European Commission, 2016). The reforms have helped create a more professional and specialized agriculture sector in the EU. This is especially true of the EU-10. Compared to the

\footnotetext{
${ }^{49}$ EU-10 refers to the ten new countries that joined the European Union in 2004, which were: Czech Republic, Estonia, Cyprus, Latvia, Lithuania, Hungary, Malta, Poland, Slovenia, and Slovakia.
} 
EU-15, for instance, the EU-10 counts more managers with full agricultural training (in contrast to practical experience only). Other contributing factors to improvements in agricultural productivity and competitiveness relate to the development of knowledge, modernization, the sharing of risks and costs, and the creation of synergies. This suite of improvements was implemented primarily through 'shared farming' models and other types of cooperatives, which expanded sharply in the EU-10 after 2010.

Following the introduction of decoupled payments, a significant shift from small to mediumsized farms occurred between 2007-2010, resulting in the emergence of a more viable, market-oriented farm structure. As in the case of New Zealand, the EU has experienced a restructuring of its agriculture sector as a consequence of recent policy reforms; some small and inefficient farms have disappeared, while those that remained have become larger both in terms of land area and economic size.

The immediate effect on the EU-10 from accessing the EU Single Market and implementing the EU agricultural policies was an increase in demand for agricultural products. Thanks to their improved competitiveness and to greater economies of scale, the EU-10 have been able to fulfill the rising demand for agricultural products, both among the EU-15 and outside the EU. EU10 exports from 2004 to 2013 rose more than threefold (+246 percent), resulting in the bloc shifting from being a net importer of agricultural products to a net exporter (European Commission 2014).

Ecuador has recently been taking measures to diversify into novel export-oriented agricultural products, such as quinoa, plantains, dragon fruits (pitahayas), malangas, avocados, sweet potatoes, ginger, coconuts, small grapes (uvilla), blackberries, tree tomatoes (tomato de arbol) and meat. Achieving global competitiveness for these crops will entail understanding how to structure alternative, decoupled agricultural incentives. Here, lessons from New Zealand, the EU, and other regional counterparts such as Brazil and Uruguay are useful. The acquisition of such understanding could involve desk research as well as study tours. Topics of particular relevance include how to upgrade technologies, how to adapt incentives for climate smart agriculture, and how to provide more sophisticated training and territorial planning (especially through sustainable landscape approaches). 


\section{a. References}

Aghion, Philippe, Bloom, Nick, Blundell, Richard, Griffith, Rachel and Peter Howitt. 2005. "Competition and innovation: An inverted U relationship." The Quarterly Journal of Economics, 120(2), 701-728.

Aguiar, Victor and Luis Casto. 2015. "Minimum Wage in Ecuador: A pseudo-panel analysis 2003:2014.” Tech. Representative, World Bank. Unpublished.

Alaimo, Verónica, Bosch, Mariano, Kaplan, David, Pagés, Carmen and Laura Ripani. 2015. “Jobs for Growth.” Inter-American Development Bank.

Alaimo, Veronica, Bosch, Mariano and Mela Gualavisi. 2017. "Measuring the Cost of Salaried Labor in Latin America and the Caribbean." Technical Note No (IDB-TN-1291), Inter-American Development Bank.

Antràs, Pol, Chor, Davin, Fally, Thibault and Russell Hillberry. 2012. "Measuring the upstreamness of production and trade flows." American Economic Review, 102(3), 412-16.

Baensch, Laura, Lanzalot, María Laura, Lotti, Giulia and Rodolfo Stucchi. 2018. "Do Labor Market Regulations Affect the Link between Innovation and Employment? Evidence from Latin America." Tech. Representative, Inter-American Development Bank.

Balassa, Bela. 1965. "Trade Liberalisation and 'Revealed' Comparative Advantage." The Manchester School, 33(2), 99-123.

Baldwin, Richard and Javier Lopez-Gonzalez. 2015. "Supply-chain trade: A portrait of global patterns and several testable hypotheses." The World Economy, 38(11), 1682-1721.

Bartelsman, Eric, Haltiwanger, John and Stefano Scarpetta. 2013. "Cross-Country Differences in Productivity: The Role of Allocation and Selection." American Economic Review, 103(1), 30534.

Bernard, Andrew and J. Bradford Jensen. 1999. "Exceptional Exporter Performance: Cause, Effect, or Both?” Journal of International Economics, 47(1), 1-25.

Policy, 20(3), 343-357.

2004. Exporting and Productivity in the USA. Oxford Review of Economic

Bernard, Andrew, Jensen, J. Bradford, Redding, Stephen and Peter Schott. 2007. "Firms in International Trade." Journal of Economic Perspectives, 21(3), 105-30.

Besley, Timothy and Robin Burgess. 2004. "Can labor regulation hinder economic performance? Evidence from India.” The Quarterly Journal of Economics, 119(1), 91-134.

Botero, Juan, Djankov, Simeon, La Porta, Rafael, Lopez-de-Silanes, Florencio and Andrei Shleifer. 2004. "The regulation of labor.” The Quarterly Journal of Economics, 119, 1339-1382.

Brown, Charles. 1999. "Minimum wages, employment, and the distribution of income.” Handbook of Labor Economics, 3, 2101-2163. 
Código del Trabajo. s.f. Registro Oficial Suplemento 167 - Modificado Sep 2102, Available at http://www.trabajo.gob.ec/wp-content/uploads/2015/03/CODIGO-DEL-TRABAJO-1.pdf.

"Doing Business.” 2019. Washington, DC.: The World Bank.

Dunning, John. 1993. "International direct investment patterns". In The Global Race for Foreign Direct Investment (pp. 107-132). Springer, Berlin, Heidelberg.

Engel, Jakob, Winkler, Deborah and Thomas Farole. 2016. "SACU in Global Value Chains." World Bank Working Paper 102987.

Eslava, Marcela, Haltiwanger, John, Kugler, Adriana and Maurice Kugler. 2004. "The effects of structural reforms on productivity and profitability enhancing reallocation: evidence from Colombia." Journal of Development Economics, 75(2), 333-371.

Freeman, Richard. 2008. "When workers share in profits: Effort and responses to shirking." Centre for Economic Performance, London School of Economics and Political Science.

Gachet, Ivan, Grijalva, Diego, Uribe-Teran, Carlos and Paul Ponce. 2018. “Ecuador's Income Tax Dataset (2001-2017)." Available from the authors.

Giugale, Marcelo, Fretes-Cibils, Vicente and Eduardo Somensatto. 2008. "Revisiting Ecuador's economic and social agenda in an evolving landscape." The World Bank.

Guzman, Lya and Salomón Salcedo. 2014. "Agricultura Familiar en América Latina y el Caribe: Recomendaciones de Política.” FAO.

Haddad, Mona, Harrison, Ann and Catherine Hausman. 2011. "Decomposing the Great Trade Collapse: Products, Prices, and Quantities in the 2008-2009 crisis." The World Bank.

Hausmann, Ricardo and César Hidalgo. "The Atlas of Economic Complexity." The Observatory of Economic Complexity (Harvard HKS/CDI - MIT Media Lab).

Heckman, James, Pagés, Carmen, Cox-Edwards, Alejandra and Pablo Guidotti. 2000. "The cost of job security regulation: evidence from Latin American labor markets." Journal of the Latin American and Caribbean Economic Association, 1(1),109-154.

Heckman, James and Carmen Pages. 2004. "Law and Employment: Lessons from Latin America and the Caribbean." University of Chicago Press. Available from:

https://chicago.universitypressscholarship.com/10.7208/chicago/9780226322858.001.0001/upso9780226322827.

Hill, Ruth, Inchauste, Gabriela, Lustig, Nora, Tsehaye, Eyasu and Tassew Woldehanna. 2017. "A Fiscal Incidence Analysis for Ethiopia.” CEQ Institute Working Paper N 41, 79-111.

IADB. 2015. "Labor Markets and Social Security Information System." Available from https://www.iadb.org/en/sector/social-investment/sims/home: Inter-American Development Bank. 
ILO. 2017. "Minimum Wage Policy Guide." Tech. Representative, International Labour Organization.

IMF. 2006. "Ecuador: Selected Issues.” IMF Country Report 06/103; International Monetary Fund.

2012. "Encuesta Nacional de Ingresos y Gastos de los hogares urbanos y rurales 2011- 2012, Resumen Metodológico y Principales Resultados.” INEC.

2014. "Guía de uso para las series históricas de la Encuesta de Superficie y Producción Agropecuaria Continua (ESPAC).” INEC.

2016. "Metodología ESPAC.” INEC.

2017. "Metodolodgía de empresas y establecimientos 2017.” INEC.

2018. "Directorio de Empresas. Instituto Nacional de Estadítica y Censos." Available from: http://www.ecuadorencifras.gob.ec/directoriodeempresas/.

Jara, Xavier. 2018. "Unemployment insurance and income protection in Ecuador." WIDER Working Paper 2018/151, UNU Wider.

Jaramillo, Miguel and Jaime Saavedra. 2005. "Severance Payment Programs in Latin America." Empirica, 32(3-4), 275-307.

Jellema, Jon, Lusig, Nora, Hass, Astrid and Sebastian Wolf. 2016. "Fiscal Incidence in Uganda." CEQ Institute Working Paper N 53.

Koopman, Robert, Powers, William, Wang, Zhi and Shang-Jin Wei. 2010. "Give Credit where Credit is Due: Tracing value added in global production chains." No. 16426, National Bureau of Economic Research.

Kugler, Adriana. 1999. "The impact of firing costs on turnover and unemployment: Evidence from the Colombian labour market reform.” International Tax and Public Finance, 6, 389-410.

2004. "The effect of job security regulations on labor market flexibility. Evidence from the Colombian Labor Market Reform." In Law and Employment: Lessons from Latin America and the Caribbean, 183-228. University of Chicago Press.

Lall, Sanjaya. 2000. “The Technological structure and performance of developing country manufactured exports, 1985-98.” Oxford Development Studies, 28(3), 337-369.

Lenzen, Manfred, Moran, Daniel, Kanemoto, Keiichiro and Arne Geschke. 2013. "Building Eora: A Global Multi-Region Input-Output Database at High Country and Sector Resolution." Economic Systems Research, 25(1), 20-49.

Ley de Transformación Económica. 2000. Registro Oficial, No. 144.

Lowder, Sarah, Skoet, Jakob and Terri Raney. 2016. "The Number, Size, and Distribution of Farms, Smallholder Farms, and Family Farms Worldwide.” FAO, Rome. 
Lustig, Nora. 2017. "El impacto del sistema tributario y el gasto social en la distribución del ingreso y la pobreza en América latina. Una aplicación del marco Metodológico del proyecto compromiso con la equidad." CEQ Institute Working Paper No. 37.

MacIsaac, Donna and Martin Rama. 1997. "Determinants of Hourly Earnings in Ecuador: The Role of Labor Market Regulations.” Journal of Labor Economics, 15(3), 136-65.

Bank Publications.

1999. "Do labor market regulations affect labor earnings in Ecuador?" World

Maletta, Héctor. 2011. "Tendencias y perspectivas de la Agricultura Familiar en América Latina, Documento de Trabajo $N^{\circ}$ 1. Proyecto Conocimiento y Cambio en Pobreza Rural y Desarrollo." RIMISP (Centro Latinoamericano para el Desarrollo Rural); Santiago, Chile.

Marinakis, Andrés. 1999. "Worker participation in company profits or operating results in Latin America." CEPAL Review, 69, 69-82.

2016. "Non-compliance with minimum wage laws in Latin America: The importance of institutional factors." International Labour Review, 155(1), pp.133-156.

Melitz, Marc. 2003. "The impact of Trade on Intra-industry Reallocations and Aggregate Industry Productivity." Econometrica, 71(6), 1695-1725.

Ministerio de Trabajo. 2019. "Salarios Mínimos Sectoriales 2019." Available from: http://www.trabajo.gob.ec/wp-content/plugins/download-monitor/download.php?id=3634\& force $=1$.

Mogro, Segundo, Ordenana-Rodriguez, Xavier and Paúl Vera-Gilces. 2019. "Microeconometric Evidence between Exporters and Non-Exporters: Differences in Economic and Productivity Performance". Superintendencia de Compañías, Ecuador. Mimeo.

Oviedo, Ana-Maria. 2009. "Economic informality: Causes, costs, and policies: A literature survey of international experience." Background Paper prepared for Country Economic Memorandum (CEM)--Informality: Causes, Consequences, Policies.

Perry, Guillermo, Arias, Omar, Fajnzylber, Pablo, Maloney, William, Mason, Andrew and Jaime Saavedra-Chanduvi. 2007. "Informality: Exit and exclusion." The World Bank.

Rhoades, Stephen. 1993. “The Herfindahl-Hirschman Index.” Federal Reserve Bulletin, 79, 188189.

Sehnbruch, Kirsten and Rafael Carranza. 2014. "Unemployment Insurance based on Individual Savings Accounts: Lessons for other Latin American and Developing Countries from Chile." Serie de Documentos de Trabajo SDT 401, Universidad de Chile.

Wong, Sara. 2019. "Minimum Wage Impacts on Wages and Hours Worked in Low-Income Workers in Ecuador." World Development, 116(C), 77-99. 
World Bank. 2017. “2017|2018 Global Investment Competitiveness Report: Foreign Investor Perspectives and Policy Implications.”

-------------- 2018. “Ecuador - Systematic Country Diagnostic.” Tech. Representative, World Bank.

World Trade Organization. 2019. "Ecuador Trade Policy Review.” January (19-0080).

Younger, Stephen, Myamba, Flora and Kenneth Mdadila. 2016. "Fiscal Incidence in Tanzania." CEQ Institute Working Paper No. 36, 1-32.

Younger, Stephen, Osei-Assibey, Eric and Felix Oppong. 2015. "Fiscal Incidence in Ghana." CEQ Institute Working Paper No. 35, 1-47. 


\section{b. Annexes}

\section{i. Empirical exercise to estimate foreign firms' markups.}

We apply an econometric approach to test how foreign-owned firms compared to locally-owned enterprises. If foreign-owned firms have better production techniques, better management and processes, and more access to capital, then they should be able to outperform local firms in a range of dimensions of firm-level performance. We employ a similar model to that of Bernard and Jensen (1999 and 2004) to estimate the markup of foreign firms. We estimated the following regression:

$$
\operatorname{lny}_{i t}=\alpha_{j t}+\beta \text { foreign }_{i t}+\delta \ln \text { size }_{i t}+\rho \ln a g e_{i t}+\varepsilon_{i t}
$$

where yit is a set of performance variables that include total revenue, production, value added, wage bill, total assets, investment, equity, exports and imports for firm $i$ in year $t$. Foreign, the variable of interest, equals 1 if at least 10 percent of firm $i$ 's equity is owned by a foreign entity. The exponentiated coefficient $\exp (\beta)$ for foreign is the ratio of the expected geometric mean for the foreign-owned group over the expected geometric mean for the locally-owned group, when size and age are controlled for. Therefore, the value $\exp (\beta)-1$ represents the markup of foreignowned enterprises. These are the coefficients that are presented in Error! Reference source not found. $\alpha \_j t$ are industry-year fixed effects. Results are displayed in the table below.

\begin{tabular}{|c|c|c|c|c|c|c|c|c|c|c|}
\hline VARIABLES & $\begin{array}{c}(1) \\
\ln (T F P)\end{array}$ & $\begin{array}{c}(2) \\
\text { In(revenue) }\end{array}$ & $\begin{array}{c}(3) \\
\text { In(produccion) }\end{array}$ & $\begin{array}{c}\text { (4) } \\
\text { In (value added) }\end{array}$ & $\begin{array}{c}\text { (5) } \\
\text { In(wage bill) }\end{array}$ & $\begin{array}{c}(6) \\
\text { In (assets) }\end{array}$ & $\begin{array}{c}(7) \\
\text { In (investment) }\end{array}$ & $\begin{array}{c}\text { (8) } \\
\text { In (equity) }\end{array}$ & $\begin{array}{c}\text { (9) } \\
\text { In (exports) }\end{array}$ & $\begin{array}{c}(10) \\
\text { In (imports) }\end{array}$ \\
\hline FDI & $\begin{array}{c}0.042 \\
{[0.007]^{\star \star \star}}\end{array}$ & $\begin{array}{c}0.612 \\
{[0.012]^{\star \star \star}}\end{array}$ & $\begin{array}{c}0.120 \\
{[0.004]^{\star \star *}}\end{array}$ & $\begin{array}{c}0.110 \\
{[0.005]^{\star \star \star}}\end{array}$ & $\begin{array}{c}0.162 \\
{[0.007]^{\star \star \star}}\end{array}$ & $\begin{array}{c}0.673 \\
{[0.008]^{\star \star \star}}\end{array}$ & $\begin{array}{c}0.500 \\
{[0.013]^{\star \star \star}}\end{array}$ & $\begin{array}{c}0.620 \\
{[0.009]^{\star \star \star}}\end{array}$ & $\begin{array}{c}0.818 \\
{[0.018]^{\star \star \star}}\end{array}$ & $\begin{array}{c}1.582 \\
{[0.024]^{\star \star \star}}\end{array}$ \\
\hline In_age & $\begin{array}{c}-0.020 \\
{[0.002]^{\star \star *}}\end{array}$ & $\begin{array}{c}0.312 \\
{[0.004]^{\star \star *}}\end{array}$ & $\begin{array}{c}0.081 \\
{[0.001]^{\star * *}}\end{array}$ & $\begin{array}{c}0.144 \\
{[0.002]^{\star \star *}}\end{array}$ & $\begin{array}{c}0.192 \\
{[0.002]^{\star * *}}\end{array}$ & $\begin{array}{c}0.377 \\
{[0.002]^{\star \star \star}}\end{array}$ & $\begin{array}{c}-0.114 \\
{[0.004]^{\star * *}}\end{array}$ & $\begin{array}{c}0.636 \\
{[0.003]^{\star \star \star}}\end{array}$ & $\begin{array}{c}0.087 \\
{[0.004]^{\star * *}}\end{array}$ & $\begin{array}{c}0.340 \\
{[0.006]^{\star * *}}\end{array}$ \\
\hline In_size & $\begin{array}{c}0.162 \\
{[0.001]^{\star \star *}}\end{array}$ & $\begin{array}{c}0.952 \\
{[0.003]^{\star * *}}\end{array}$ & $\begin{array}{c}0.939 \\
{[0.001]^{\star * *}}\end{array}$ & $\begin{array}{c}0.910 \\
{[0.001]^{\star * *}}\end{array}$ & $\begin{array}{c}0.710 \\
{[0.002]^{\star \star \star}}\end{array}$ & $\begin{array}{c}0.611 \\
{[0.002]^{\star \star \star}}\end{array}$ & $\begin{array}{c}0.693 \\
{[0.003]^{\star \star *}}\end{array}$ & $\begin{array}{c}0.544 \\
{[0.002]^{\star \star \star}}\end{array}$ & $\begin{array}{c}0.209 \\
{[0.002]^{\star * *}}\end{array}$ & $\begin{array}{c}0.572 \\
{[0.003]^{\star \star \star}}\end{array}$ \\
\hline Constant & $\begin{array}{c}2.008 \\
{[0.005]^{\star \star \star}}\end{array}$ & $\begin{array}{c}-4.412 \\
{[0.010]^{\star \star \star}}\end{array}$ & $\begin{array}{c}-0.774 \\
{[0.004]^{\star \star \star}}\end{array}$ & $\begin{array}{c}-1.617 \\
{[0.004]^{\star \star \star}}\end{array}$ & $\begin{array}{c}-2.462 \\
{[0.006]^{\star \star \star}}\end{array}$ & $\begin{array}{c}-1.684 \\
{[0.007]^{\star \star \star}}\end{array}$ & $\begin{array}{c}-2.161 \\
{[0.010]^{\star * *}}\end{array}$ & $\begin{array}{c}-3.581 \\
{[0.007]^{\star \star \star}}\end{array}$ & $\begin{array}{c}-13.044 \\
{[0.009]^{\star * *}}\end{array}$ & $\begin{array}{c}-11.289 \\
{[0.016]^{\star \star \star}}\end{array}$ \\
\hline Observations & 175,952 & 399,720 & 415,283 & 394,434 & 387,572 & 442,289 & 250,125 & 406,967 & 443,709 & 443,709 \\
\hline R-squared & 0.453 & 0.390 & 0.897 & 0.843 & 0.705 & 0.671 & 0.555 & 0.601 & 0.329 & 0.376 \\
\hline
\end{tabular}




\section{ii. Institutional frameworks for trade and investment: Chile, Costa Rica, and Ireland.}

\section{Chile}

Chile is an example of a country that has recently modernized its institutional framework for investment attraction. Institutional restructuring started in 2015, with the creation of the Comite de Ministros para el Fomento y Promoción de la Inversión Extranjera and the agency InvestChile. The main role of the Comité de Ministros is to formulate strategic polices for investment promotion, directly endorsed by the president. It carries out the functions of a ministerial council, meeting at least twice a year and chaired by the Ministerio de Economia, Fomento, y Turismo. The Comite is also composed of the Ministry of Finance and other ministries that the president considers have a role in investment policy and promotion. Meanwhile, InvestChile - the country's investment promotion agency - acts as the permanent body for the Comité de Ministros. It is responsible for the implementation of policies designed to attract FDI into the country.

InvestChile was created under the supervision of the Ministry of Economy, Planning and Tourism. It aims to replace the functions carried by the Corporación de Fomento de la Producción (CORFO), Chile's economic development agency. InvestChile has the mandate to focus on attracting investment in the mining, food, tourism, and energy industries. Its responsibilities also anticipate the provision of investor services beyond investment attraction. In this respect, it seeks to facilitate investment retention and expansion in the country, as well as offer aftercare services to investors.

On May 2018, a fresh initiative was launched to bolster Chile's efforts to facilitate FDI. A central goal of this additional reform, which concentrates on implementation as well as policy making, was to simplify the bureaucracy that foreign investors face. To lead this endeavor, the government created the Comité Asesor de Proyectos Sustentables. This policy-making body comprises the subsecretaries of the ministries for the priority sectors targeted by InvestChile. As with the Comite de Ministros, it is chaired by the Ministry of Economy. The Comite Asesor is aided at the implementation level by the Oficina de Gestion de Proyectos Sustentables (GPS). The GPS brings together experts from the different priority sectors. Unlike the Comite Asesor, which only meets once a month, the GPS serves as a permanent body and, as such, provides a single window for investors entering in the country for sustainable projects.

Another objective of GPS is to assist investors in solving their grievances before they escalate into disputes. Ultimately, the GPS and InvestChile focus on the same priority sectors and offer assistance jointly to investors both before and after they invest. This synergy allows Chile to expand its ability to attract and retain FDI.

\section{Costa Rica}

Costa Rica provides a model of what a well-aligned institutional framework looks like for trade and investment. When consolidating its institutional approach back in the 1990s, the Costa Rican government placed an emphasis on creating institutions that were technically oriented as well as highly specialized. Indeed, key to the country's success is the technical capacity of the Ministry of 
Foreign Trade (COMEX), which, as the lead ministry, is responsible for formulating the country's trade policy and for negotiating its trade and investment agreements. Over successive political cycles, COMEX has succeeded in forming a stable team of technocrats, thus ensuring policy consistency and continuity. The same can be said for both PROCOMER (Costa Rica's export promotion agency) and CINDE (Costa Rica's investment promotion agency).

One peculiarity of CINDE is its non-governmental nature. Established in 1982 as a private entity, its initial objective was to help the government drive a series of economic liberalization reforms and to insert Costa Rica into global markets. Since the mid-1990s, it has reoriented its mandate to become an IPA. Although CINDE retains its financial and institutional autonomy, it is linked to COMEX and implements policies formulated by COMEX as the lead ministry. CINDE mainly focuses on attracting efficiency-seeking FDI, specifically in high-tech sectors. Currently, Costa Rica is globally recognized as a manufacturing hub for high-tech medical devices, as well as a strong exporter of IT services. This is a reflection of CINDE's strategic efforts at attracting FDI.

In addition, CINDE has focused on becoming an investor-centric organization. Not only does it offer assistance to foreign investors when they are selecting sites for investment, but it also provides aftercare services once investor are operating in the country. In this way, it maintains a close, ongoing relationship with investors, which positions it well to address their needs and concerns. Through its aftercare services, CINDE also tries to maximize reinvestment and expansion opportunities of the multinational companies that are already established in the country.

PROCOMER, the export promotion agency created in 1996, primarily assists small and mediumsized enterprises (SMEs) to export goods and services abroad. Of all the companies that it assisted in 2017, over three-quarters (76 percent) were either SMEs or micro enterprises.

The case of Costa Rica not only provides an example of a well-aligned and successful trade and FDI institutional framework. It also illustrates the value of high-quality institutional arrangements. Moreover, it proves that such arrangements can be achieved with limited means and resources. According to the agency's own data, COMEX's annual budget amounted to \$17.8 million in 2017. Its staff numbers, meanwhile, were less than 90 people. At $\$ 4.5$ million, CINDE's 2017 budget was even smaller; its employees numbered 47 people. As for PROCOMER, its annual budget for 2017 amounted to $\$ 18.9$ million and its staff roll call ran to 195 people.

Ireland

Ireland represents another example of a country that has established a very successful institutional framework for investment. Instead of a standing ministerial council, Ireland creates working groups on an ad hoc basis to formulate new investment priorities. These high-level groups include representatives from different ministries as well as relevant subject experts from the private sector. The Department of Business, Enterprise, and Innovation (DBEI) acts as the lead ministry and coordinates investment policy. A strong lead ministry has marked a long-standing constant of the Irish institutional framework for investment. This may seem surprising as the ministry was only organized as DBEI in 2014. Yet, the core functions of all Ireland's trade agencies have remained consistent over time. The focus of the country's political agenda around FDI as a source of jobs 
creation has also remained stable. According to DBEI, the country's trajectory from 16 percent unemployment in 2008 to almost full employment today gives weight to the argument that the country's FDI policy acts as a stimulus to employment.

Ireland's investment promotion agency, the Industrial Development Agency (IDA), has a 45-year track record of achievement. It was set up as an autonomous state-sponsored body in 1969, a time when Ireland was not regarded as an attractive investment destination. Over the decades, IDA has managed to change global perceptions and has helped transform Ireland into a powerhouse of FDI attraction. Ireland now has a cumulative FDI stock of $€ 304$ billion, equivalent to 168 percent of its GDP.

With the single mandate of attracting FDI, IDA has always pursued an industrial development strategy that seeks to target industries in which Ireland could achieve a competitive advantage. This strategy has seen it target three industries in particular over recent decades: the life sciences industry, which today employs around 35,000 people in Ireland; the information and communications technology industry, which currently counts 220 multinational investors that employ about 38,000 people and posts exports worth $\$ 64$ billion; and the international financial services, which presently employs about 19,000 people. IDA has succeeded in building a critical mass of firms in each one of these three target sectors, thus creating a self-reinforcing, clustering effect.

A national consensus towards promoting Ireland's insertion into global markets and improving the country's investment climate has proved vital. This consensus has been built from the 1960s onwards. It was aided by a social partnership agreement that saw government, employers, labour unions, farmers, and non-governmental organizations collaborate closely. Through such collaboration, Ireland was able to moderate wage increases and cut taxes, as well as agree on national development priorities. A good example of the latter relates to labour skills, which were identified as low and therefore a constraint on investment. To correct this shortfall, the government committed to invest heavily in public education and training. Particular attention was given to the key technology sectors that IDA was targeting. Guiding this process was an expert group that was set up in 1997 to identify the critical skills that Ireland would require in the future.. Today, about 30 percent of college students in Ireland graduate in science and engineering, while a further 25 percent graduate in business. 


\section{iii. Impact of the Pacific Alliance on the Competitiveness of Ecuadorian Exporters and Importers}

Treatment Effect on Ecuadorian Exports to Pacific Alliance Countries

\begin{tabular}{lccc}
\hline & Log Export Value & Log Export Value & Log Export Value \\
& $(1)$ & $(2)$ & $(3)$ \\
\hline & & & $-1.982^{* * *}$ \\
Treated*Post-2010 & $-1.431^{* * *}$ & $-0.934^{* * *}$ & $(0.199)$ \\
& $(0.143)$ & $(0.270)$ & $1.650^{* * *}$ \\
Post-2010 & $1.204^{* * *}$ & $0.764^{* * *}$ & $(0.166)$ \\
& $(0.0898)$ & $(0.101)$ & \\
Sample & & & Importer-Exporters \\
Firms & All Exporters & Pure Exporters & 2812 \\
Observations & 5946 & 3520 & 16823 \\
R-squared & 35782 & 17883 & 0.705 \\
\hline
\end{tabular}

Note: This table shows the treatment effect of the Pacific Alliance on firm exports to Pacific Alliance countries. The regression specification is as in Box 6. The dependent variable is log exports to Chile, Colombia, Mexico, and Peru.

\section{Treatment Effect on Ecuadorian Imports from Pacific Alliance Countries}

\begin{tabular}{lccc}
\hline & Log Import Value & Log Import Value & Log Import Value \\
& $(1)$ & $(2)$ & $(3)$ \\
\hline & & & $-1.719^{* * *}$ \\
Treated*Post-2010 & $-1.601^{* * *}$ & $(0.0748)$ & $(0.190)$ \\
Post-2010 & $(0.0694)$ & $0.511^{* * *}$ & $1.251^{* * *}$ \\
& $0.597^{* * *}$ & $(0.0316)$ & $(0.162)$ \\
Sample & $(0.0318)$ & & \\
Firms & & Pure Importers & Importer-Exporters \\
Observations & All Importers & 26364 & 2812 \\
R-squared & 27556 & 152632 & 16823 \\
\hline
\end{tabular}

Note: This table shows the treatment effect of the Pacific Alliance on firm imports from Pacific Alliance countries. The regression specification is as in Box 6. The dependent variable is log exports to Chile, Colombia, Mexico, and Peru. 


\section{Treatment Effect on Probability of Survival in Export and Import Markets}

\begin{tabular}{lcc}
\hline & $\begin{array}{c}\text { Prob of Exporting } \\
(1)\end{array}$ & $\begin{array}{c}\text { Prob of Importing } \\
(2)\end{array}$ \\
\hline \multirow{3}{*}{ Treated } & -0.0196 & 0.00292 \\
& $(0.0217)$ & $(0.00980)$ \\
Constant & $0.677^{* * *}$ & $0.764^{* * *}$ \\
& $(0.0125)$ & $(0.00501)$ \\
Firms & 2105 & 9714 \\
\hline
\end{tabular}

Note: This table shows the treatment effect of the Pacific Alliance on the probability of survival in export and import markets. We identify all firms that were active in export or import markets for at least three years between 2002 and 2010. The dependent variable is an indicator for whether the firm remained active for at least three years between 2011 and 2017. The independent variables are a constant and an indicator for treated firms. We use a linear probability model, although the results are similar using nonlinear models.

Treatment Effect on Ecuadorian Exports and Imports over Time

\begin{tabular}{lcc}
\hline & $\begin{array}{c}\text { Log Export Value } \\
(1)\end{array}$ & $\begin{array}{c}\text { Log Import Value } \\
(2)\end{array}$ \\
\hline & -0.0494 & 0.0370 \\
Treated*Year 2011 & $(0.0625)$ & $(0.0243)$ \\
Treated*Year 2012 & -0.0955 & 0.00541 \\
& $(0.0666)$ & $(0.0266)$ \\
Treated*Year 2013 & $-0.161^{* *}$ & -0.0367 \\
& $(0.0767)$ & $(0.0292)$ \\
Treated*Year 2014 & -0.0896 & -0.0189 \\
& $(0.0795)$ & $(0.0302)$ \\
Treated*Year 2015 & $-0.243^{* * *}$ & 0.0246 \\
& $(0.0827)$ & $(0.0333)$ \\
Treated*Year 2016 & $-0.253^{* * *}$ & 0.0514 \\
& $(0.0863)$ & $(0.0372)$ \\
Treated*Year 2017 & $-0.384^{* * *}$ & $0.0728^{*}$ \\
& $(0.0897)$ & $(0.0384)$ \\
Sample & & \\
Firms & All Exporters & All Importers \\
Observations & 5946 & 27556 \\
R-squared & 35782 & 171517 \\
\hline
\end{tabular}

Note: This table shows how the treatment effect of the Pacific Alliance evolves over time. The dependent variable in Column 1 is log total exports and the sample is all exporters. The dependent variable in Column 2 is $\log$ total importers and the sample is all importers. The independent variables are a firm fixed-effect, an indicator for each year from 2011-2017, and an indicator for treated firms interacted with an indicator for each year from 2011-2017. For brevity, we only report the coefficient on the interaction term. 


\section{iv. Effects of Ecuador's Trade Protection on Productivity, Value Added, and Factor Misallocation.}

Effects of trade protection on value added and productivity growth (Fixed effects)

\begin{tabular}{|c|c|c|c|c|c|c|c|c|}
\hline \multirow[t]{2}{*}{ VARIABLES } & \multicolumn{4}{|c|}{$\Delta \ln ($ value added) } & \multicolumn{4}{|c|}{$\Delta \ln (\mathrm{tfp})$} \\
\hline & (1) & $(2)$ & (3) & $(4)$ & $(5)$ & $(6)$ & $(7)$ & $(8)$ \\
\hline Nominal protection (ad-valorem) & $\begin{array}{c}1.576 \\
{[0.684]^{\star \star}}\end{array}$ & & & & $\begin{array}{c}0.958 \\
{[1.900]}\end{array}$ & & & \\
\hline Nominal protection (compound) & & $\begin{array}{c}-0.025 \\
{[0.012]^{\star \star}}\end{array}$ & & & & $\begin{array}{c}-0.047 \\
{[0.021]^{\text {** }}}\end{array}$ & & \\
\hline Effective protection (ad-valorem) & & & $\begin{array}{c}1.245 \\
{[0.461]^{\star \star \star}}\end{array}$ & & & & $\begin{array}{c}0.533 \\
{[1.050]}\end{array}$ & \\
\hline Effective protection (compound) & & & & $\begin{array}{c}-0.013 \\
{[0.007]^{\star}}\end{array}$ & & & & $\begin{array}{c}-0.028 \\
{[0.011]^{\star *}}\end{array}$ \\
\hline Constant & $\begin{array}{c}-0.193 \\
{[0.083]^{\star *}}\end{array}$ & $\begin{array}{c}-0.074 \\
{[0.053]}\end{array}$ & $\begin{array}{c}-0.106 \\
{[0.059]^{*}}\end{array}$ & $\begin{array}{c}-0.062 \\
{[0.052]}\end{array}$ & $\begin{array}{c}-0.137 \\
{[0.178]}\end{array}$ & $\begin{array}{c}-0.057 \\
{[0.059]}\end{array}$ & $\begin{array}{c}-0.085 \\
{[0.081]}\end{array}$ & $\begin{array}{c}-0.061 \\
{[0.059]}\end{array}$ \\
\hline Sector FE & Yes & Yes & Yes & Yes & Yes & Yes & Yes & Yes \\
\hline Year FE & Yes & Yes & Yes & Yes & Yes & Yes & Yes & Yes \\
\hline Observations & 1,167 & 1,167 & 1,157 & 1,157 & 1,014 & 1,014 & 1,014 & 1,014 \\
\hline R-squared & 0.236 & 0.235 & 0.246 & 0.244 & 0.028 & 0.028 & 0.028 & 0.028 \\
\hline
\end{tabular}

Robust standard errors in brackets ${ }^{* \star} p<0.01,{ }^{\star *} p<0.05,{ }^{*} p<0.1$

Effects of trade protection on resource misallocation and market concentration

(Fixed effects, 2007-2017)

\begin{tabular}{|c|c|c|c|c|c|c|c|c|}
\hline \multirow[t]{2}{*}{ VARIABLES } & \multicolumn{4}{|c|}{$\Delta \ln ($ value added $)$} & \multicolumn{4}{|c|}{$\Delta \ln (\mathrm{tfp})$} \\
\hline & (1) & $(2)$ & (3) & (4) & (5) & (6) & (7) & (8) \\
\hline Nominal protection (ad-valorem) & $\begin{array}{c}1.576 \\
{[0.684]^{* *}}\end{array}$ & & & & $\begin{array}{c}0.958 \\
{[1.900]}\end{array}$ & & & \\
\hline Nominal protection (compound) & & $\begin{array}{c}-0.025 \\
{[0.012]^{\star *}}\end{array}$ & & & & $\begin{array}{c}-0.047 \\
{[0.021]^{\text {** }}}\end{array}$ & & \\
\hline Effective protection (ad-valorem) & & & $\begin{array}{c}1.245 \\
{[0.461]^{\star * *}}\end{array}$ & & & & $\begin{array}{c}0.533 \\
{[1.050]}\end{array}$ & \\
\hline Effective protection (compound) & & & & $\begin{array}{c}-0.013 \\
{[0.007]^{*}}\end{array}$ & & & & $\begin{array}{c}-0.028 \\
{[0.011]^{* *}}\end{array}$ \\
\hline Constant & $\begin{array}{c}-0.193 \\
{[0.083]^{\star *}}\end{array}$ & $\begin{array}{c}-0.074 \\
{[0.053]}\end{array}$ & $\begin{array}{c}-0.106 \\
{[0.059]^{*}}\end{array}$ & $\begin{array}{c}-0.062 \\
{[0.052]}\end{array}$ & $\begin{array}{l}-0.137 \\
{[0.178]}\end{array}$ & $\begin{array}{c}-0.057 \\
{[0.059]}\end{array}$ & $\begin{array}{l}-0.085 \\
{[0.081]}\end{array}$ & $\begin{array}{l}-0.061 \\
{[0.059]}\end{array}$ \\
\hline Sector FE & Yes & Yes & Yes & Yes & Yes & Yes & Yes & Yes \\
\hline Year FE & Yes & Yes & Yes & Yes & Yes & Yes & Yes & Yes \\
\hline Observations & 1,167 & 1,167 & 1,157 & 1,157 & 1,014 & 1,014 & 1,014 & 1,014 \\
\hline R-squared & 0.236 & 0.235 & 0.246 & 0.244 & 0.028 & 0.028 & 0.028 & 0.028 \\
\hline
\end{tabular}




\section{v. Data: Labor Reform Analysis}

Data on minimum wages across countries on local currency were collected from the International Labor Organization (ILOSTAT). For a few years, we also used labor legislation from Ecuador, Chile, Brazil, Mexico, and El Salvador to compensate for missing minimum wage data. Then, minimum wages were converted to U.S. dollars using exchange rate, national currency to U.S. dollars reported in Penn Tables. Finally, we computed minimum wages in PPP international U.S. dollars using PPP conversion factor from World Development Indicators (WDI). We also used average wages for formal workers minimum wages in PPP international 2011 from IADB's labor market data (IADB, 2015) and GDP per worker in PPP international 2011 from WDI.

The cost of salaried labor as a percentage of wages and the annual value of paying a worker the minimum wage were taken from Alaimo, Bosch and Gualavisi (2017). This was also the case for all mandatory benefits included as a share of GDP in international and regional peer countries. This comprises the most recent comparable data available with comparable wage and non-wage costs across Latin American countries for 2013.

Wage and non-wage costs by sector were computed using industry survey from the Ecuador Institute of Statistics (INEC). These surveys are repeated, cross-section data implemented from 1997 to 2015 with a sample of firms with more than ten employees for a sample of more than 3,000 . The sample covers three sectors of the economy; manufacturing, commerce, and services. Wage and non-wage data were homologated across years so as to have a comparable series of these variables as well as computed shares of these variables on total labor costs and wages (only for non-wage costs). Then, we computed the shares of wage and non-wage costs in real terms for industry, commerce and services using aggregate deflectors data published by the Central Bank. The Central Bank publishes deflectors desegregated at the industry level, but industry surveys have inconsistencies registering ISIC-codes that make it unfeasible to merge specific industry deflectors to the survey. Value added for the services sector only considers data from five industries: hotels and restaurants, transport, financial intermediation, water, and electricity. In addition, only real, stated activities that correspond to industries identified in the survey were considered. Also, we used a computed number of workers by sector using the tax dataset employed by Gachet et al. (2018), which was constructed using labor surveys from 2001 to 2017. We consider formal workers as those contributing to the social security system from 2001 to 2017 in manufacturing, commerce and services. We then used this calculation to compute the value added per worker for each sector. Then, we estimated the ratio of wage and non-wage costs to the value added per worker in each sector. This measures the labor total cost of hiring a formal worker in each sector relative to the average productivity of each sector. Data limitations meant we could only make this comparison from 2002 onwards. Finally, we computed growth rates for wage and non-wage variables using the year 2000 as a reference year. We excluded data before 2000 to compute growth rated because the information is registered in sucres (official currency before 2000) and converting variables to U.S. dollars generates a break in the series. 


\section{vi. Data: Agricultural Price Support Policies}

Data mainly stem from open databases published by the Statistical Institute of Ecuador (INEC), such as the Encuesta Nacional de Ingresos y Gastos de Hogares Urbanos y Rurales (ENIGHUR), the Encuesta de Superficie y Producción Agropecuaria Continua (ESPAC), and the Encuesta Nacional de Empleo, Desempleo y Subempleo (ENEMDU). In addition, we draw on the InputOutput Matrix publicized by the Ecuadorian Central Bank.

The ENIGHUR database provides information on the amount, distribution, and structure of wages at an individual level as well as consumption at household level (INEC 2012). The data derive from a survey of 40,932 households that was undertaken between April 2011 and March 2012. A probabilistic, two-stage sampling method has been applied for auto-representative cities in which census tracts are the primary sample unit and households are the secondary sample unit. Within the other domains, a three-stage sampling method has been applied. In this case, towns have been treated as primary sample units, census tracts as secondary sample units, and households as third level units. Data provided by ENIGHUR can be considered as statistically representative at urban and rural provinces levels, as well as at city level in nine cases: Ambato, Cuenca, Esmeraldas, Guayaquil, Loja, Machala, Manta, Quito, and Santo Domingo.

The ENEMDU is the main survey to evaluate the employment status of Ecuadorians. It also comprises core indicators for Ecuador's labour markets as well as household incomes for the monitoring of poverty and inequality. The survey has representativeness at national, urban, and rural level. It is also representative for the main five cities: Quito, Guayaquil, Cuenca, Machala, and Ambato. ENEMDU is collected on a quarterly basis in March, June, September, and December. Data are available from June 2007 onwards. We used the round of December 2016 since this is the most recent year for which we have data on market prices support. For that year, we have variables with household members' characteristics, labour-related indicators, and dwelling characteristics for 30,338 households.

Finally, the ESPAC is a survey providing data on the pattern of production and sales in the agricultural sector for all the potential crops and animals raised in Ecuador INEC (2016). INEC has published this survey yearly since 2002, albeit with some methodological changes. Questionnaires collect information on: (a) general characteristics of the land dedicated (or not) to agricultural activities; (b) the quantity of crops planted, harvested, and either sold or consumed, for each different type of crop; (c) the quantity of bovine, porcine, ovine, and poultry raised, sold, or consumed, plus the amount of eggs and milk produced, sold or consumed; and (d) characteristics of workers employed in agricultural activities.

With the intent of improving the level of accuracy for estimates, we combined area sampling with a list that includes the main farmers operating within each area. Since 2014, 5,638 portions of land and 3,969 farmers have been selected in each ESPAC survey. According to the technical note published by INEC (2014), methodological changes since 2014 did not generate a substantial break for the most important crops in the case of planted and harvested quantities at national level. Nevertheless, significant changes occurred for time series related with the crops that are produced and sold. Consequently, the data provided has to be considered with a break before and after 2014 . Besides, according to INEC technical note (2016), information must be used at a national level to guarantee estimates with a coefficient of variation lower than 15 percent. Up to 2016 at least, disaggregated data at province level show degrees of inaccuracy that are too high to be considered usable. 
The aim of this study was to analyze the dynamic of products with minimum price support. The quality of the data determined which products could be analyzed. As ESPAC is the official survey to generate data about agricultural activity, it was used to create a descriptive analysis for all the crops with minimum price support. On the other hand, ENIGHUR has not been designed to provide information at product level. Therefore, before developing any analysis with ENIGHUR, it was necessary to evaluate the comparability among ENIGHUR and ESPAC, ${ }^{50}$ considering the total farmer population in Ecuador as well as the number of family farmers.

As it is possible to observe from the table below, some concerns appear in the case of soft corn, soya, barley, wheat, banana, sugar cane, porcine, ovine, and poultry. In fact, as clarified by the table, ENIGHUR data are not representative - or at least are not a proxy - of the real distribution of the production of these foodstuffs, neither using all the farmers nor just family-based farmers. Moreover, it is necessary to stress that livestock products such as bovine do not profit from minimum price support, although the data show them as comparable. For the same reason, eggs were not considered for the analysis.

As for ENIGHUR, the importance of milk means that its data regarding this commodity are included in the analysis, although the external validity of this data is not possible to verify. The analysis developed in this study using ENIGHUR also focuses on corn and rice.

Quantities produced according to ESPAC and ENIGHUR, Ecuador

\begin{tabular}{lccccc}
\hline & $\begin{array}{c}\text { ESPAC } \\
\text { Total }\end{array}$ & $\begin{array}{c}\text { ESPAC } \\
\text { Family } \\
\text { farming }\end{array}$ & ENIGHUR & $\begin{array}{c}\text { ENIGHUR / } \\
\text { ESPAC Total }\end{array}$ & $\begin{array}{c}\text { ENIGHUR / ESPAC } \\
\text { Family Farm. }\end{array}$ \\
\hline Corn & $860,378.00$ & $676,588.06$ & $862,521.00$ & $\mathbf{1 0 0 \%}$ & $78 \%$ \\
Soft corn & $102,884.00$ & $70,900.97$ & $158,747.00$ & $65 \%$ & $45 \%$ \\
Soya & $39,555.29$ & $21,492.45$ & $97,993.00$ & $40 \%$ & $22 \%$ \\
Barley & $24,704.00$ & $8,498.14$ & $14,328.00$ & $172 \%$ & $59 \%$ \\
Rice & $1,477,941.00$ & $656,154.18$ & $1,303,299.00$ & $\mathbf{1 1 3 \%}$ & $50 \%$ \\
Wheat & $5,938.00$ & $3,436.02$ & $6,981.00$ & $85 \%$ & $49 \%$ \\
Banana & $7,427,776.00$ & $158,267.89$ & $741,440.00$ & $1002 \%$ & $21 \%$ \\
Sugar cane & $8,131,819.00$ & $938,807.59$ & $588,486.00$ & $1382 \%$ & $160 \%$
\end{tabular}

\footnotetext{
${ }^{50}$ All the variables related to crops have been transformed in metric tons. In the case of livestock products, no transformation was needed as the data in both surveys are in units. Milk and eggs are the source of some concern as it is not possible to compare outputs generated by the two databases. In the case of milk, this is because data in ENIGHUR are collected jointly with yogurt and serum. The issue with the data for eggs, meanwhile, relates to the measurement indicators used; data in ENIGHUR are provided in metric tons, while data in ESPAC appear in units.
} 


\begin{tabular}{lccccc} 
Other crops & $3,494,665.71$ & $1,295,027.88$ & $3,628,138.00$ & $\mathbf{9 6 \%}$ & $36 \%$ \\
\hline Bovine & $5,358,904$ & $2,882,453$ & $3,053,420.00$ & $176 \%$ & $\mathbf{9 4 \%}$ \\
Porcine & $1,831,066$ & 776,857 & $2,433,731.00$ & $75 \%$ & $32 \%$ \\
Ovine & 742,963 & 629,891 & $895,915.00$ & $83 \%$ & $70 \%$ \\
Poultry & $49,228,537$ & $13,059,997$ & $26,272,411.00$ & $187 \%$ & $50 \%$ \\
\hline Milk* & $6,375,237$ & $2,816,142$ & $609,801,463$ & & Not comparable \\
Eggs** & $48,150,092$ & $7,389,830$ & 45,692 & & \\
\hline Source: Data elaborated by consultant using ENIGHUR and ESPAC. & \\
*In ENIGHUR, milk is jointly considered with yogurt and serum \\
**Eggs as MT in ENIGHUR and as units in ESPAC
\end{tabular}

Distribution of characteristics in households with and without agricultural activities.

\begin{tabular}{|c|c|c|}
\hline & $\begin{array}{c}\text { Households with no } \\
\text { agricultural activities }\end{array}$ & $\begin{array}{c}\text { Household with } \\
\text { agricultural activities }\end{array}$ \\
\hline \multicolumn{3}{|l|}{ Area } \\
\hline Urban & $84.8 \%$ & $16.1 \%$ \\
\hline Rural & $15.2 \%$ & $83.9 \%$ \\
\hline \multicolumn{3}{|l|}{ Region } \\
\hline Amazonia & $3.4 \%$ & $8.3 \%$ \\
\hline Costa & $53.0 \%$ & $37.7 \%$ \\
\hline Sierra & $43.6 \%$ & $54.0 \%$ \\
\hline \multicolumn{3}{|l|}{ Sex (head of household) } \\
\hline Male & $74.0 \%$ & $82.8 \%$ \\
\hline Female & $26.0 \%$ & $17.2 \%$ \\
\hline \multicolumn{3}{|l|}{ Ethnicity (head of household) } \\
\hline Indigenous & $3.2 \%$ & $18.0 \%$ \\
\hline Afroecuatorian & $5.8 \%$ & $3.1 \%$ \\
\hline Montubio & $5.0 \%$ & $10.6 \%$ \\
\hline Mestizo & $82.0 \%$ & $65.9 \%$ \\
\hline Caucasian & $4.0 \%$ & $2.4 \%$ \\
\hline $\begin{array}{l}\text { Average age (head of } \\
\text { household) }\end{array}$ & 46.6 & 53.4 \\
\hline
\end{tabular}


Average numbers of household components

Education (head of household)

$\begin{array}{rrr}\text { No education } & 5.1 \% & 17.2 \% \\ \text { Primary } & 37.9 \% & 64.5 \% \\ \text { Secondary } & 34.9 \% & 14.4 \% \\ \text { Tertiary } & 22.1 \% & 3.9 \%\end{array}$

\begin{tabular}{|c|c|c|c|}
\hline \multicolumn{4}{|l|}{ Deciles of expenditure } \\
\hline & 1 & $5.5 \%$ & $23.8 \%$ \\
\hline & 2 & $7.8 \%$ & $16.9 \%$ \\
\hline & 3 & $8.9 \%$ & $13.5 \%$ \\
\hline & 4 & $9.6 \%$ & $11.0 \%$ \\
\hline & 5 & $10.4 \%$ & $8.7 \%$ \\
\hline & 6 & $10.9 \%$ & $7.3 \%$ \\
\hline & 7 & $11.3 \%$ & $6.2 \%$ \\
\hline & 8 & $11.5 \%$ & $5.3 \%$ \\
\hline & 9 & $11.9 \%$ & $4.1 \%$ \\
\hline & 10 & $12.2 \%$ & $3.2 \%$ \\
\hline $\begin{array}{l}\text { Average expenditure per } \\
\text { capita (U.S. dollars) }\end{array}$ & & 279.8 & 157.5 \\
\hline $\begin{array}{l}\text { Number of households } \\
\text { (sample) }\end{array}$ & & 30,815 & 8,802 \\
\hline $\begin{array}{l}\text { Number of households } \\
\text { (population) }\end{array}$ & & $2,960,665$ & 961,247 \\
\hline
\end{tabular}

Source: Data elaborated using ENIGHUR 2011 